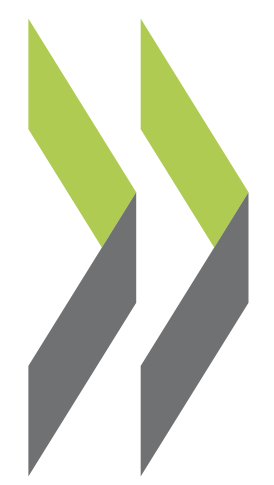

OECD Social, Employment and Migration Working Papers No. 122

\title{
Redistribution Policy and Inequality Reduction in OECD Countries: What Has Changed in Two Decades?
}

Herwig Immervoll, Linda Richardson 
Organisation de Coopération et de Développement Économiques

Organisation for Economic Co-operation and Development

DIRECTORATE FOR EMPLOYMENT, LABOUR AND SOCIAL AFFAIRS

English - Or. English

Redistribution Policy and Inequality Reduction in OECD Countries:

What has changed in two decades?

Herwig Immervoll and Linda Richardson

JEL Classification:

C81, D31, H22, H55

Key words:

income inequality, redistribution, working-age, OECD

All Social, Employment and Migration Working Papers are now available through the OECD website at www.oecd.org/els/workingpapers

Complete document available on OLIS in its original format

This document and any map included herein are without prejudice to the status of or sovereignty over any territory, to the delimitation of international frontiers and boundaries and to the name of any territory, city or area. 


\title{
DIRECTORATE FOR EMPLOYMENT, LABOUR AND SOCIAL AFFAIRS
}

www.oecd.org/els

\section{OECD SOCIAL, EMPLOYMENT AND MIGRATION WORKING PAPERS}

\author{
www.oecd.org/els/workingpapers
}

OECD Working Papers should not be reported as representing the official views of the OECD or of its member countries. The opinions expressed and arguments employed are those of the author(s).

Working Papers describe preliminary results or research in progress by the author(s) and are published to stimulate discussion on a broad range of issues on which the OECD works. Comments on Working Papers are welcomed, and may be sent to the Directorate for Employment, Labour and Social Affairs OECD, 2 rue André-Pascal, 75775 Paris Cedex 16, France.

This series is designed to make available to a wider readership selected labour market, social policy and migration studies prepared for use within the OECD. Authorship is usually collective, but principal writers are named. The papers are generally available only in their original language - English or French with a summary in the other.

\section{Applications for permission to reproduce or translate all or part of this material should be made to:}

\author{
Head of Publications Service \\ OECD \\ 2, rue André-Pascal \\ 75775 Paris, CEDEX 16 \\ France
}

Copyright OECD 2011 


\section{ACKNOWLEDGEMENTS}

This paper has been prepared by Herwig Immervoll who, at the time of writing was a senior economist at the OECD Social Policy Division and is currently senior economist at the World Bank, and Linda Richardson, policy analyst at the OECD Social Policy Division. We thank Michael Förster for helpful discussions as well as Tony Atkinson, Brian Nolan, Markus Jäntti, Timothy Smeeding and colleagues from the OECD Economics Department and the Directorate for Employment, Labour and Social Affairs for providing us with valuable comments at different stages of the drafting process.

This report has been produced with the assistance of the European Union, as part of a joint OECD/EU project "Tax Wedge and Effective Tax Rates on Labour". This working paper should not be reported as representing the official views of the OECD or of its member countries. The opinions expressed and arguments employed are those of the author(s). In particular, the contents of this publication can in no way be taken to reflect the views of the European Union. 


\begin{abstract}
We use a range of data sources to assess if, and to what extent, government redistribution policies have slowed or accelerated the trend towards greater income disparities in the past 20-25 years. In most countries, inequality among "non-elderly" households has widened during most phases of the economic cycle and any episodes of narrowing income differentials have usually not lasted long enough to close the gap between high and low incomes that had opened up previously. With progressive redistribution systems in place, greater inequality automatically leads to more redistribution, even if no policy action is taken. We find that, in the context of rising market-income inequality, tax-benefit systems have indeed become more redistributive since the 1980s but that this did not stop income inequality from rising: market-income inequality grew by twice as much as redistribution. Between the mid-1990s and the mid-2000s, the redistributive strength of tax-benefit systems then weakened in many countries. While growing marketincome disparities were the main driver of inequality trends between the mid-1980s and mid-1990s, reduced redistribution was often the main reason why inequality rose in the ten years that followed. Benefits had a much stronger impact on inequality than social contributions or taxes, despite the much bigger aggregate size of direct taxes. As a result, redistribution policies were often less successful at counteracting growing income gaps in the upper parts of the income distribution.
\end{abstract}

\title{
RÉSUMÉ
}

Nous utilisons une série de sources de données afin d'évaluer si, et dans quelle mesure, les politiques de redistribution du gouvernement ont ralenti ou accéléré la tendance vers une aggravation des disparités de revenus dans les 20-25 dernières années. Dans la majorité des pays, l'inégalité parmi les ménages de "nonpersonnes âgées" s'est élargi pendant la plupart des phases du cycle économique et des épisodes de rétrécissement d'écarts de revenus n'ont généralement pas duré assez longtemps pour réduire l'écart entre les revenus élevés et faibles qui se sont ouverts auparavant. Avec les systèmes de redistribution progressive en place, une plus grande inégalité conduit automatiquement à une plus grande redistribution, même si aucune décision politique n'est prise. Nous constatons que, dans le contexte de la hausse de l'inégalité du revenu du marché, les systèmes socio-fiscaux ont en effet devenu plus redistributifs depuis les années 80 mais cela n'a pas empêché les inégalités de revenu à augmenter : l'inégalité du revenu du marché a augmenté de deux fois plus que la redistribution. La force de redistribution des systèmes socio-fiscaux s'est affaiblie dans de nombreux pays en particulier dans la dernière décennie. Alors que l'augmentation des disparités du revenu du marché a été le principal moteur de l'évolution des inégalités entre les années 80 et 90, la réduction de redistribution était souvent le principal moteur dans les dix ans qui ont suivi. Les bénéfices ont eu un impact beaucoup plus fort sur les inégalités que les cotisations sociales ou les impôts, malgré l'importance plus grande de l'ensemble des impôts directs. En conséquence, les politiques de redistribution ont souvent connu moins de succès à contrecarrer les écarts de revenus croissants dans les parties supérieures de la répartition des revenus. 


\section{TABLE OF CONTENTS}

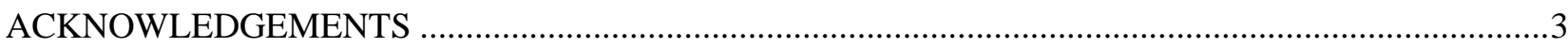

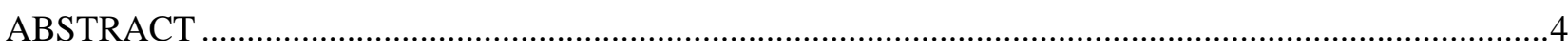

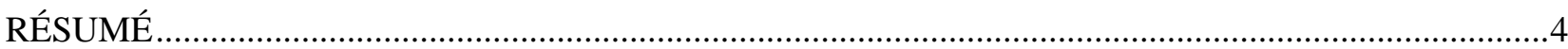

REDISTRIBUTION POLICY AND INEQUALITY REDUCTION IN OECD COUNTRIES: WHAT HAS

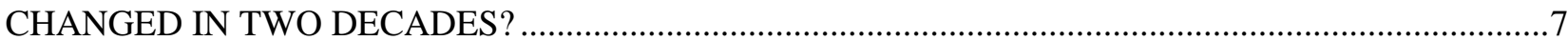

INTRODUCTION

1.1 The need for redistribution: more or less acute than 20 years ago? ...........................................11

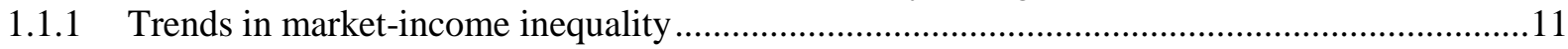

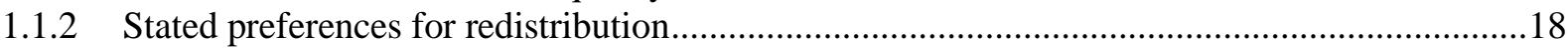

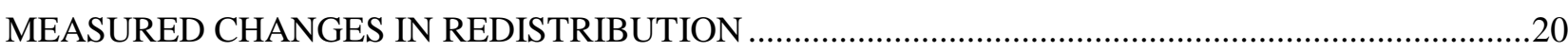

2.1 The size of the redistribution system: aggregate expenditures and revenues................................22

2.2 Changes in the extent of redistribution: some evidence from household income data ....................31

2.2.1 Redistribution in the tax-benefit systems as a whole.............................................................

2.2.2 Did changes in redistribution affect mainly families with higher or lower incomes? ...............40

2.2.3 A closer look at the role of different parts of the redistribution system ....................................

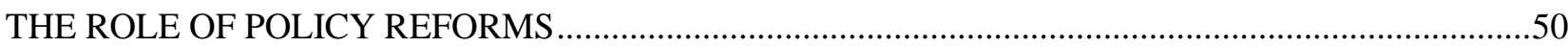

3.1 The reach of benefit systems: more or less encompassing? ........................................................50

3.2 Key features of redistribution systems and major policy changes in selected countries..................54

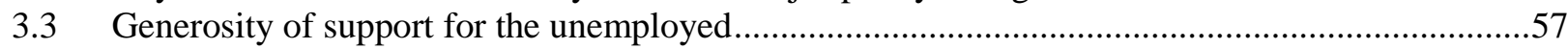

3.4 Gainers and losers of tax-benefit reforms across the earnings distribution ...............................60

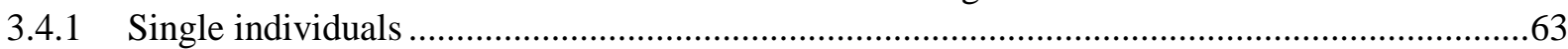

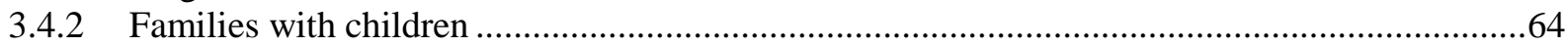

3.4.3 Consequences of policy reforms for people's position in the income distribution....................65

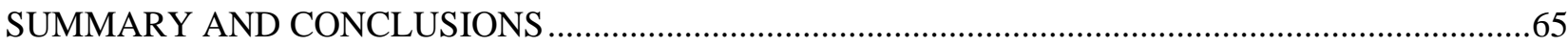

4.1 Compared with the mid-1990s, tax-benefit systems are now less effective at reducing inequality 66

4.2 Changes in overall redistribution were mainly driven by the benefit system ................................66

4.3 Tax reforms have contributed little to inequality reduction .....................................................67

4.4 What lessons for future redistribution policies? ..........................................................................67

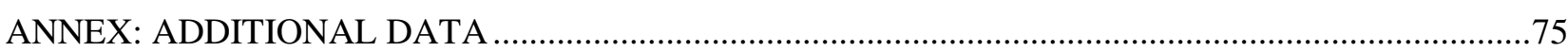

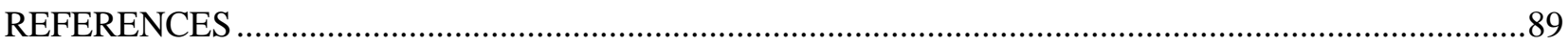




\section{Tables}

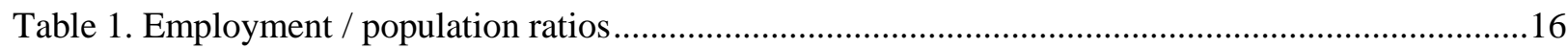

Table 2. Average market incomes for different income groups........................................................... 17

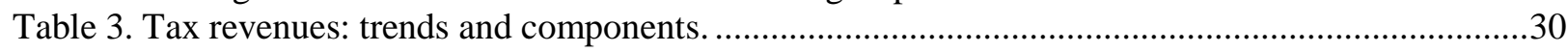

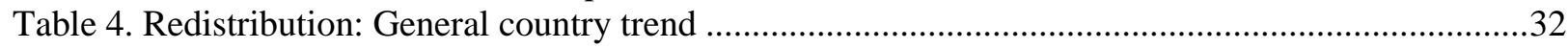

Table 5. Redistribution trends: Detailed results by country .....................................................................34

Table 6. Redistribution systems generally compensated a greater part of growing inequalities at the

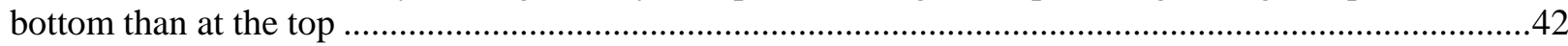

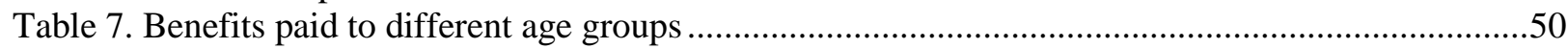

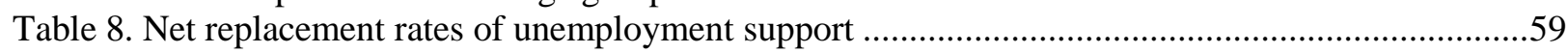

\section{Figures}

Figure 1. Widening gaps: Market incomes at different points in the distribution ...................................14

Figure 2. Across countries, stated preferences show no clear trend towards either less or more

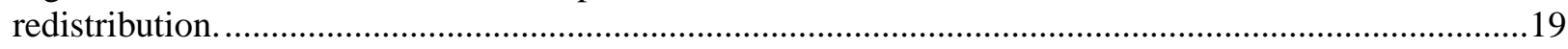

Figure 3. Overall amounts of taxes paid and benefits received in the mid-2000s ...................................21

Figure 4. Total social expenditure levels increased, but cash transfers for the non-elderly often did not. 23

Figure 5. Public social expenditure: total and cash benefits for the non-elderly ....................................26

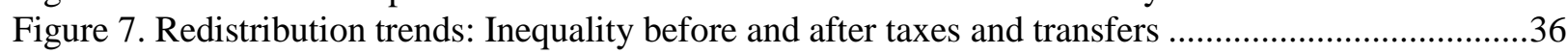

Figure 8. Redistribution tends to be higher when incomes are more unequal ......................................40

Figure 9. Drivers of redistribution: Progressivity and size of transfers and taxes ..................................47

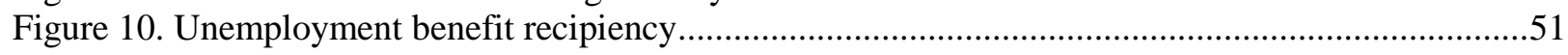

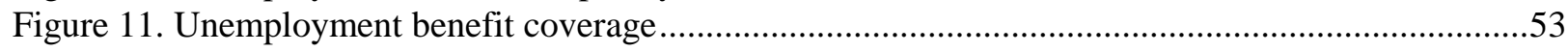

Figure 12. Net replacement rates of unemployment support ............................................................58

Figure 13. Gains and losses 1995-2005: policy changes and fiscal-drag .............................................69

Figure 14. Position in the income distribution under different policy scenarios ....................................72

\section{Boxes}

Box 1. Inequality and redistribution: scope and measurement choices ..............................................

Box 2. Measuring redistribution achieved by individual parts of the tax-transfer system..........................44

Box 3. Isolating the direct effect of policy reforms: An illustration for the United States..........................60 
DELSA/ELSA/WD/SEM(2011)7

\section{REDISTRIBUTION POLICY AND INEQUALITY REDUCTION IN OECD COUNTRIES: WHAT HAS CHANGED IN TWO DECADES?}

\section{INTRODUCTION}

1. Over the past 20-25 years, household incomes have become more unequally distributed in most OECD countries, sometimes substantially so. This is true for the population as a whole, as well as for households headed by working-age individuals. In addition to widening income inequalities in the upper half of the distribution, and a growing share of incomes earned at the very top, there has been a worrying trend towards a greater incidence of very low incomes, with headcount measures of relative poverty going up in 16 out of 24 countries (OECD, 2008a). Since the recent economic downturn may reduce top incomes, it need not result in an unambiguous further increase in overall inequality. Yet, groups who were already disadvantaged before the economic crisis are typically more likely to see their incomes deteriorate further (OECD, 2011c; Immervoll and Peichl, 2011). In addition, expenditure cuts implemented in countries that seek to reduce spending levels can significantly erode the redistributive capacity of government budgets.

2. This paper asks if, and to what extent, government redistribution policies have slowed or accelerated the trend towards greater income disparities between people living in "non-elderly" households. The objectives are to take stock of tax and transfer redistribution policies in OECD countries prior to the onset of the recent recession, and to summarise policy changes over the past two decades. In doing so, we aim to provide input into the debate over the changing role of redistribution policies after the so-called Golden Age of the Welfare State (Pierson, 1995). One relevant question in this debate is how policies have adapted in the context of economic and demographic changes. In particular, have policy and economic changes, such as patterns of unemployment, low-wage work and working time, combined to reduce the redistributive role of the welfare state, or did they mainly change the type of redistribution taking place, without eroding the overall capacity for reducing inequality?

3. Following common usage of the term, we use "redistribution" to mean reduction of household income inequality. The paper is one element of a series of OECD studies of the drivers of observed inequality trends among working-age individuals and their families. The project, entitled Causes of Growing Inequalities, includes analyses of the factors behind changes in the distribution of labour incomes, as well as a discussion of trends at the very top of the income distribution, where capital incomes represent a larger share of total household resources (OECD, 2011d). As in other parts of this project, changes in the income distribution are analysed using "snapshots" for individual years, and the group of interest is working-age individuals and their families. The reference period is the mid-1980s to the mid2000s. Box 1 provides details on scope and measurement choices.

4. There exist several recent and detailed national studies of redistribution trends (e.g., Riihelä et al., 2008 for Finland, Adam and Browne, 2010 and Glennerster, 2006 for the UK). International 
comparisons tend to focus on specific parts of the tax-benefit system (Heady et al., 2001, Wagstaff and van Doorslaer, 2001, Wagstaff et al., 1999). Multi-country comparative studies that consider the entire taxbenefit system are rare, and mostly limited to a particular point in time (Immervoll et al., 2006, AttaDarkua and Barnard, 2006). Point-in-time comparisons are sometimes thought problematic since large institutional differences between countries, notably in terms of the balance between public and private provision or cash transfers versus benefits in-kind, make it difficult to interpret country differences in terms of a particular portion of the redistribution system (Blackburn and Bloom, 1994). This is less of an issue when the focus is on comparing changes across countries, as overall institutional setups (as well as measurement choices in the underlying data) tend to vary less over time than they do cross-nationally.

5. This paper extends and deepens the analysis in OECD (2008a, ch. 4). It attempts to gauge the effects of taxes and benefits over a longer time period and for as many countries as data permit. ${ }^{1}$ Unlike most existing studies, it explicitly focuses on the non-elderly population. ${ }^{2}$ The reasons for excluding the elderly include the following. First, it is in line with a principal objective of the Causes of Growing Inequalities project, which is to examine drivers of observed changes in the distribution of incomes from work. It is therefore interesting to ask if, and to what extent, government redistribution has counteracted trends in earnings inequality specifically. Second, restricting the analysis to the non-elderly avoids some of the problems that are inherent in comparing incomes between people who are at very different stages of their lives. For instance, an essential function of old-age pensions is to redistribute intertemporally over the life cycle; a focus on the non-elderly helps in understanding the most important elements of interpersonal redistribution. Finally, with growing pressure on public budgets due to ageing populations, an important question is whether welfare-state provisions benefiting the working-age population are being restrained in order to finance support for the elderly.

6. In addition to documenting trends in redistribution, it is important to explain the mechanisms that have led to the observed changes. A question of considerable policy relevance is to what extent changes can be attributed to direct policy action or to other factors that are less easily influenced by policy makers. For any given household, the taxes paid, and the benefits received, have a straightforward direct impact on the resources available for consumption. At the population level, however, the assessment of trends in the redistributive properties of tax and benefit policies is complicated by the fact that market incomes and populations change at the same time as tax and benefit policy parameters. Since tax burdens and benefit entitlements depend on incomes and population characteristics, a given tax-benefit system can become more or less effective at reducing inequalities, even if policy rules remain unchanged. For instance, when unemployment goes up, measured redistribution is likely to increase even with constant benefit amounts per jobseeker, simply because more people claim unemployment benefits. Similarly, a progressive income tax will redistribute more if taxable incomes become more dispersed (or very little if everybody earns about the same).

7. Whether intended or not, changes in market incomes and population characteristics can be a consequence of tax-benefit policy initiatives. But while tax and transfer reforms may actively seek to influence labour-market participation and other forms of household behaviour, many other factors are at

1. Earlier studies that compare changes over time between countries have not considered more recent changes, look at changes over a relatively short period of time, or cover only a few countries (e.g., Bargain and Callan, 2010; Atkinson, 2004; Jäntti, 1997; Fritzell, 1993).

2. Fritzell (1993) studies trends both for the entire population, and for households headed by non-elderly individuals. Jesuit and Mahler (2004) document trends in overall measures of redistribution for the 25-59 age-group but those results do not show what drove the observed trends (for instance, changes are not shown separately for taxes and benefits, and do not distinguish between changes in the progressivity and the size of redistribution instruments). 
play as well. The substantial gains in female employment rates over the past two decades provide a striking example of a long-term trend that is not simply a consequence of reforms to redistribution policies.

8. As drivers of distributional outcomes, earnings, labour force participation and family structures are certainly more difficult to control for policymakers than tax-benefit parameters such as tax rates, benefit amounts or entitlement rules. For policy analysis purposes, it is therefore informative to distinguish between changes in redistribution that can be directly attributed to tax-benefit policy reforms (referred to as direct policy changes in what follows), and those that have occurred as a result of the evolution of market incomes or population structures (referred to as income and population changes). To shed light on the relative importance of these two factors, they will be discussed separately as far as possible.

\section{Box 1. Inequality and redistribution: scope and measurement choices}

Economic inequality has many different dimensions and any study of inequality trends is necessarily selective in the types of inequality it considers. A number of measurement choices are crucial for the interpretation of results. Some of them are dictated by data availability, while others are a reflection of the purpose of the study at hand. The purpose in this paper is to isolate the direct impact of government redistribution policies on income inequalities among non-elderly households. Within this broad scope, the aim is to measure how cash benefits and direct taxes alter current household incomes.

\section{Inequality of what?}

The scope of inequality measures is chosen to be as consistent as possible with available income distribution data, which defines household disposable income as market income plus cash transfers minus direct taxes. Some taxes and transfers are excluded, most notably consumption taxes (also because they have no direct effect on incomes) and in-kind transfers (also because of the difficulties of accurately assigning values for these transfers to individual households). Since the focus is on working-age individuals and their families, old-age pensions are not a principal driver of the distributional outcomes of interest. Yet, public pensions can be an important income source for some families with working-age individuals, especially if early retirement is common. Although public pensions are largely designed to redistribute over the lifetime, they contain elements of inter-personal redistribution and can substitute for unemployment and related welfare benefits. They are therefore included in some parts of the analysis presented here (to the extent that they are received by non-elderly households). No attempts are made, however, to summarise the extensive pension reforms undertaken during the past 20 years (see OECD 2011b for an overview of current pension policies and some past trends). Similarly, incapacity benefits (sickness and disability), which have surpassed unemployment benefits as the main income replacement benefit for working-age individuals in a number of OECD countries, are included in some of the reported income measures, but specific policy changes are also not discussed in detail (see OECD, 2011a).

The direct taxes considered in the income concept include personal income taxes as well as compulsory social security contributions payable by workers, the self-employed, and benefit recipients. In line with most comparative income-distribution studies, they exclude payroll taxes as well as all contributions whose formal incidence is on employers. That is, such contributions are, (1) not counted as market income even if they give rise to insurance coverage or other benefits, and are (2) not included in reported measures of household taxes. Indirect taxes and taxes on wealth or property are not considered.

\section{Inequality among whom?}

The focus is on persons living in families that are headed by working-age individuals, defined as adults aged under 65 . In an effort to provide a better focus on working-age benefits (excluding early retirement and incapacity benefits), some results are reported for households headed by adults younger than 54 . In both cases, the reference population includes children and any elderly persons living in these households. In most countries, people living in institutions are excluded. In addition, earners of very high incomes are not well represented in income surveys, which underlie most of the inequality measures presented here. Trends in top incomes, and their policy implications, are discussed in OECD (2011d, chapter 10) and in Atkinson and Piketty (2010).

When reporting measures of inequality and the redistributive effect of policies, the paper mostly considers the reference population as a whole, using so-called global inequality measures. This is important as trends for different sub-groups may not follow that of the entire non-elderly population since, although less diverse than the population as 
a whole, the reference population for this study is composed of many distinct sub-groups. It is, for instance, possible that redistribution between specific groups (income-poor and non-poor households, families with and without children, low-skilled and high-skilled workers, men and women) has seen substantial changes over the period, even if a global inequality measure shows no, or little, change. The discussion illustrates experiences of some of these sub-groups, but does not attempt a systematic decomposition of total changes in redistribution into between-group and within-group components.

\section{Redistribution}

"Redistribution" is used synonymously with inequality reduction. Tax and benefit payments are therefore said to "redistribute" if they reduce inequality, regardless of the extent to which this is achieved through actual or implicit transfers from higher to lower-income groups. This definition is the one normally used by researchers, but it may not necessarily fully correspond to the usage of the term in everyday language. When used in a non-technical context, there is generally a presumption that tax-benefit systems reduce inequalities by transferring resources to those in greater economic need (i.e., by taxing people and using the revenue to finance transfers). However, public policies alter income inequality even when no interpersonal transfer takes place. For instance, a progressive tax reduces inequality by itself, even if the proceeds are not used to finance transfers, while a lump-sum tax increases it. One would generally expect a fairly close correspondence between benefit expenditures and tax revenues needed to finance them. But while large shares of total tax revenues can be spent on transfers, such a correspondence needs not (and usually does not) hold in every period as taxes finance non-benefit expenditures as well. Likewise, current benefit expenditure can be financed through non-tax sources, notably borrowing.

\section{Redistributive effect of government policies}

Government policies alter household incomes directly (through taxes and transfers), and indirectly (by creating incentives and constraints for household behaviour). To the extent that the existence of taxes and benefits causes changes in market prices and household behaviour, redistribution policies have an influence on pre-tax benefit market incomes (and economic welfare) which is not captured by looking at the amounts of taxes and benefits alone. There is a voluminous literature on the consequences of tax or benefit reforms that alter incentives to earn and declare taxable income (e.g., Giertz et al., forthcoming, and the references cited in Immervoll and Pearson, 2009). These indirect (or "second-round") effects of redistribution policies are at the heart of debates concerning their cost-effectiveness. Second-round distributional consequences of tax and transfer policies are considered in a separate OECD study (OECD, forthcoming).

\section{Reference time period}

As in most other studies of income inequality, distributions are assessed using "snapshots" of the income situation in a particular year. This is a common limitation of comparative studies in particular, and leaves aside dynamic aspects of inequality as well as the impact of taxes and transfers on life-time incomes. Several studies have in fact however suggested close links across countries between static and dynamic measures of income inequality (OECD, 2008a, Chapter 8). The limitation is significant nonetheless as it is less clear whether a close link observed across countries also carries over to an analysis of changes in redistribution over time, which is the focus here. For instance, with frequent policy changes, the effect on cross-sectional inequality of policies in force at the start and end of a twenty-year period says little about the cumulative redistribution achieved over the period as a whole. Perhaps more importantly, and as already noted, the main role of some of the benefits considered as part of the redistribution system is arguably to redistribute inter-temporally (rather than interpersonally). This is especially the case for public pensions (as well as the taxes or social security contributions needed to finance them).

As far as possible, the chosen reference time-period corresponds to the income distribution data presented in OECD (2008a), i.e., the mid-1980s to mid-2000s, with 10-year or shorter intervals, i.e., prior to the global economic downturn that started in 2008. Available income or policy data does, however, often not span this entire period and some sections discuss only more recent changes. Importantly, even where data points span the entire mid-1980s to mid-2000s period, they refer to different phases in countries' economic cycle, which is a challenge when discussing long-term trends. While little can be done about the limits of available micro-data series, an attempt is made to highlight the role of cyclical factors in redistribution patterns using more finely grained time series of aggregate government spending and revenue data.

9. A range of different data sources are needed to fully document how policy and other factors have altered the functioning of redistribution systems. Most data sources do not cover all OECD countries, or the full mid-1980s to mid-2000s period. To get as complete a picture as possible for the OECD area, the 
paper combines a number of different data sources and methodologies. Yet, most parts of the paper are necessarily limited to a subset of OECD countries, and some analyses are possible for a few countries only.

10. The structure of the paper is as follows. As a first step, the next section considers whether the need for redistribution can be seen as less or more urgent now than at different points since the mid-1980s. This is done by documenting changes in market-income inequality and providing illustrations of preferences for government redistribution now and 20 years ago. Section 3 then presents evidence on the trends in the inequality-reducing effects of taxes and benefits. The first part considers trends in aggregate spending and revenues, presents historical information on the evolution of different components, and briefly discusses the influence of cyclical factors on the observed patterns. A second part uses householdincome data to produce and compare a range of commonly used redistribution and progressivity indicators. Section 4 provides a summary of policy changes and a detailed analysis of the role of policy in driving observed redistribution trends. It uses the OECD's tax-benefit models to show the combined effects of recent policy reforms for different family types and at different points in the earnings and income distribution.

\subsection{The need for redistribution: more or less acute than 20 years ago?}

11. Before looking at trends in redistribution policies and inequality outcomes, it is useful to discuss how the resulting findings may be interpreted. The concept of redistribution as reduction in household income inequality can be applied straightforwardly in different years, and this provides the basis for a descriptive analysis of changes in redistribution indicators over time (see Section 3 below).

12. Yet, for policy-analysis purposes, a purely descriptive approach is arguably not sufficient, as the perceived need for redistribution is unlikely to remain constant over time. This can be because inequalities before redistribution have changed, or because social attitudes towards inequality have become more or less egalitarian. For instance, if market incomes became more unequal and social preferences towards inequality remained unchanged, a given extent of redistribution would appear less costly in terms of overall social welfare and additional redistribution would be desirable. Conversely, reducing inequalities would be seen as less pressing if preferences became less egalitarian (say because of more widespread concern over adverse incentive effects of redistribution), while market-income inequalities remained unchanged. Over longer periods of time, one would expect to observe changes in both social preferences and the distribution of market incomes.

\subsubsection{Trends in market-income inequality}

13. The dispersion of market incomes has in fact changed considerably. Changes in measured market incomes at the household level are due to a range of factors, including but not limited to wage inequality. Trends that are often quantitatively more important include the extent and distribution of unemployment and labour-market inactivity, working-time, family structures, as well as income pooling and family work patterns. In addition, non-labour incomes play a role, especially at the top of the distribution. Figure 1 below summarises the combined effect of these trends using data from the Luxembourg Income Study (LIS). It should be noted that it only shows relative changes, while starting points are very different across countries, with some recording much higher inequality levels than others (see Section 3). ${ }^{3}$

3. While LIS provides data for a larger set of countries, Figure 1 includes only the subset with sufficient information on the longer-term evolution of gross market incomes. For most years, gross income data for a number of countries are not available in LIS as most market incomes are recorded net of taxes or social contributions. The countries concerned are Austria, Belgium, France, Greece, Hungary, Ireland, Italy, Luxembourg, Mexico, Slovak Republic, Slovenia, Spain, as well as Russia. 
- In five of the 12 countries shown, median market incomes at the household level rose by between 10 and 20 percent over (roughly) a 20-year period in real terms (Canada, Denmark, Finland, West Germany, United States). Hence, before accounting for redistribution, "middle-class" households in these countries participated only very partially in overall economic growth, as real GDP per capita during this period roughly doubled on average. Real-term income gains were more sizable in Israel, Netherlands, Norway, Sweden and, especially, in the United Kingdom. Median market incomes fluctuated without a clear trend in Australia and Poland and essentially stagnated over the period as a whole.

- There is clear evidence that, before accounting for taxes and government transfers, the distribution of incomes has widened substantially. The initial period used for these comparisons, which is dictated by data availability, clearly matters. But even with different starting periods, market-income gaps grew in all countries but one (the Netherlands, discussed below).

- Considering the significant upwards trend in employment/population ratios shown in Table 1 for most countries, one might expect rising market-income shares at the bottom of the distribution. The Netherlands, where employment/population ratios rose by more than $40 \%$ between 1985 2005 (and the number of people with zero or very low incomes declined accordingly) indeed shows such a pattern. ${ }^{4}$ But strikingly, Figure 1 shows that it is not observed in any of the other countries for the period as a whole. For instance, despite progress in individual employment participation in the United States, market incomes at the $10^{\text {th }}$ percentile fell until the mid-1990s (by $20 \%$ between 1986-94, and by $36 \%$ between 1979-94) despite an increase in labour-force participation. Real incomes subsequently grew strongly until 2000 but then fell back so that they stagnated in real terms over the period as a whole. With the exception of the Netherlands and the United States, income levels at the $10^{\text {th }}$ percentile (the bottom decile) in all other countries are now lower than they were at the beginning of the available data series. One explanation could be that employment gains have coincided with an increase in the number of low-paid workers and part-time workers (as has also happened in the Netherlands). In addition, there has been a welldocumented trend towards employment polarisation, with sometimes increasing numbers of workless households and a large part of the employment gains made by households who already had some earnings. ${ }^{5}$

- Over the time period shown, household market incomes at the $75^{\text {th }}$ and $90^{\text {th }}$ percentiles have seen higher real-term increases than the other income groups in all countries but the Netherlands. It is important to stress that the percentile points shown in the graphs say nothing about incomes at the very top and that survey data are, in any case, not suitable for studying very high incomes. ${ }^{6}$ For instance, there is a broad consensus among many researchers studying US income distribution

4. The main policy shifts leading to this transformation are commonly agreed to be the labour-market deregulation and wage restraint following the so-called Wassenaar agreement between social partners in 1982. See, e.g., Salverda et al.(2008) and Marx (2007).

5. See Gregg et al. (2004).

6. One reason is that recorded data on capital incomes, which are very important for top earners, are known to be of lesser quality, and information on unrealised capital gains is not available in income surveys (but see Smeeding and Thompson, 2011). More fundamentally, and although sampling frames and techniques vary across sources, survey data generally do not include information on the highest-income earners at all (see Box 1). To limit the influence of differences in the treatment of high-income earners in LIS datasets for different countries and years, we follow conventional practice and top-code by limiting maximum (nonequivalised) household incomes to 10 times the median (see LIS website and Gottschalk and Smeeding, 2000). This is only relevant, however, for the Gini-type measures reported in Section 3 . It is inconsequential for the results shown in Figure 1 as p90/p50 ratios are everywhere lower than 10. 
trends since the late 1970s, that "it is the top 5\% of households that have gained, and the bottom $60 \%$ that have lost, in relative shares." (Lindert, 2000, p. 201), but that available survey data are not suitable for measuring income changes among these top 5 percent. With these limitations in mind, it is interesting to note that market incomes at the $75^{\text {th }}$ and $90^{\text {th }}$ percentiles have grown less strongly in the United States than in several other countries. ${ }^{7}$ The gains in this income range appear very large in Norway, Sweden and, particularly, the United Kingdom (Great Britain). Since the mid-90s, higher incomes also rose quickly in Finland and Poland. The data points are spaced several years apart and therefore do not capture the full income dynamics over the cycle. It appears, however, that any disruptions in the upwards trends for high-income groups during the downturns of the early 1980s and 1990s were short-lived.

- At the bottom, joblessness can take market incomes to very low levels, and to zero if all family members are without work. For instance, when ten percent of the population or more live in such households, the $10^{\text {th }}$ percentile point is will be close to zero. This can be seen during periods of rapidly rising unemployment or withdrawal from the labour force, especially if job losses result in large numbers of workless households, as is indicated for Australia, Finland and United Kingdom during the mid-1990s recessions, and for Israel and Poland later on.

- In most countries, however, market income inequality appears to widen during most phases of the economic cycle. When incomes at the bottom fall rapidly during and after recessions, incomes in the upper part of the distribution have often continued to rise at a reduced pace (Canada, Denmark and the United States for example). Where downturns do result in longer-lasting income losses for higher-income groups (as in Australia, Finland, Poland), the relative income decline tends to be significantly smaller than for low-income earners. The main exception to this pattern is the 2001-02 recession in Israel: income losses among higher earners persisted, while earnings at the bottom recovered (albeit from a level that was much lower than in the 1990s).

- In some recoveries, the lowest incomes grew more quickly than they did at the top so that incomes at the bottom managed to regain some ground (Canada from 1993, Denmark during the 1990s, Australia and Israel after 2001). But this usually followed a period of sharply declining incomes for low earners. As a result, episodes of narrowing income differentials have rarely lasted long enough to close the gap between high and low incomes that had opened up previously. In other countries, market-income gaps stagnated or continued to widen even as low incomes recovered from deep or prolonged labour-market downturns (see Finland and the United Kingdom).

7. Data drawn from tax statistics indicate that during the 2002-2007 boom period, the highest-earning $1 \%$ of all families in the United States (those earning in excess of around USD 360 000) accounted for as much as two-thirds of total market-income growth. See Atkinson et al. (2011). 
Figure 1. Widening gaps: Market incomes at different points in the distribution Household market incomes in constant prices. Earliest available data point=100.
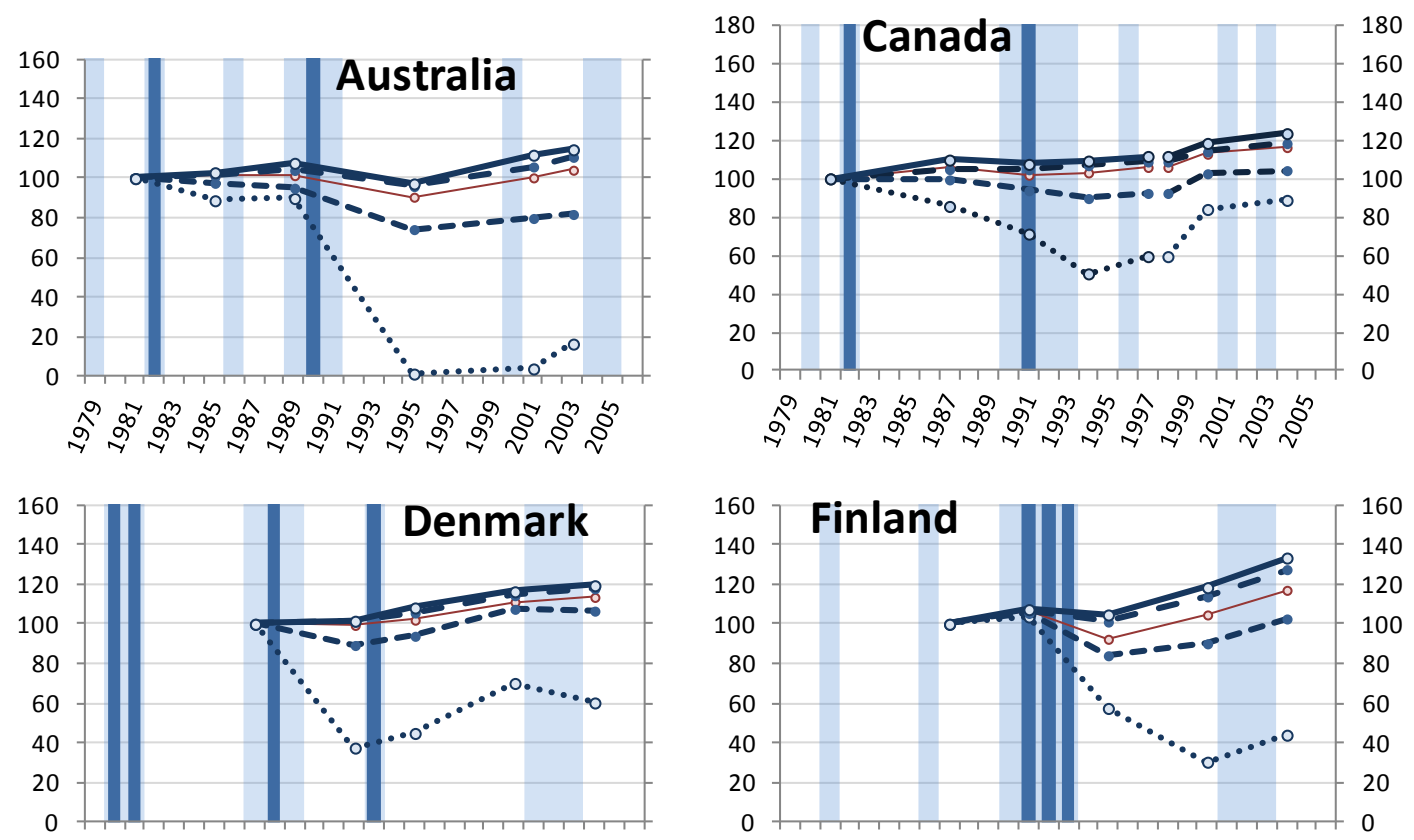

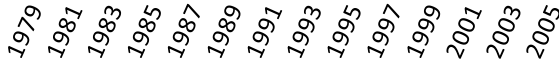

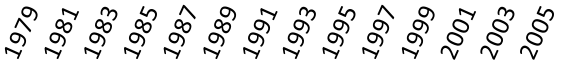
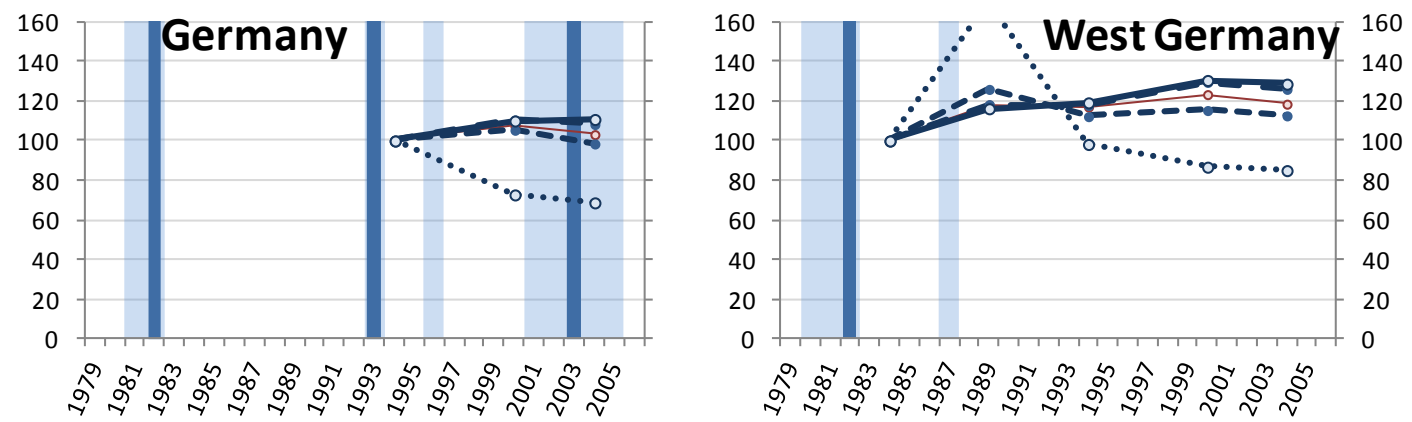

$\begin{array}{lr}\text { Negative growth years } & \text { Low-growth years } \\ \ldots \text { p50 } & \ldots \text { p75 } \\ \ldots \circ \text { p10 } & \ldots-p 25 \\ \ldots \text { p90 } & \end{array}$

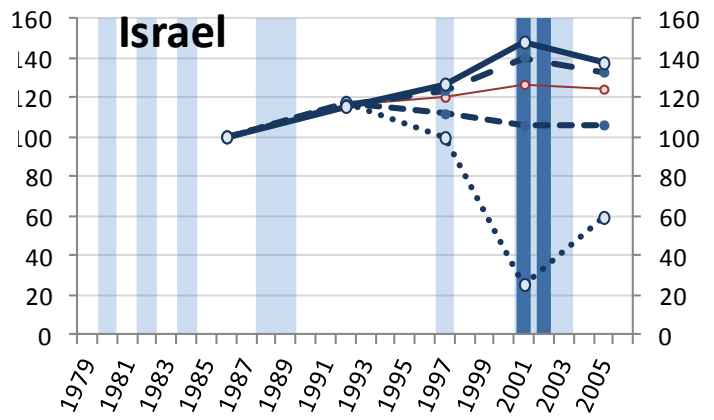


Figure 1 (continued).

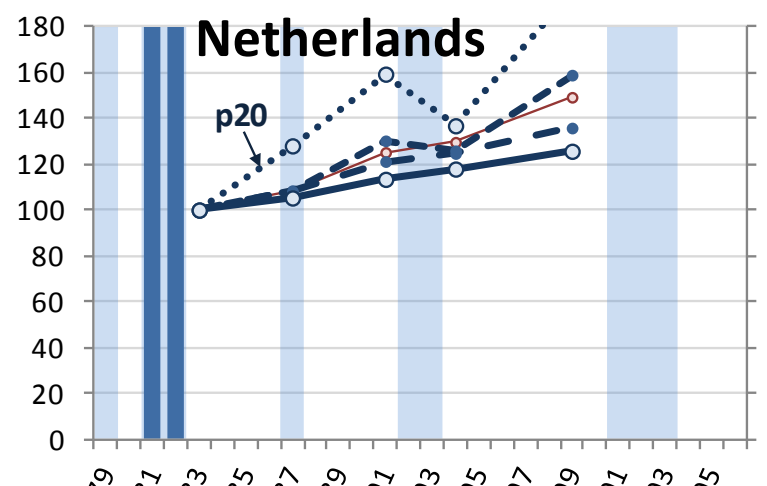

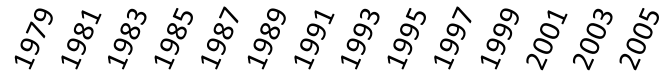

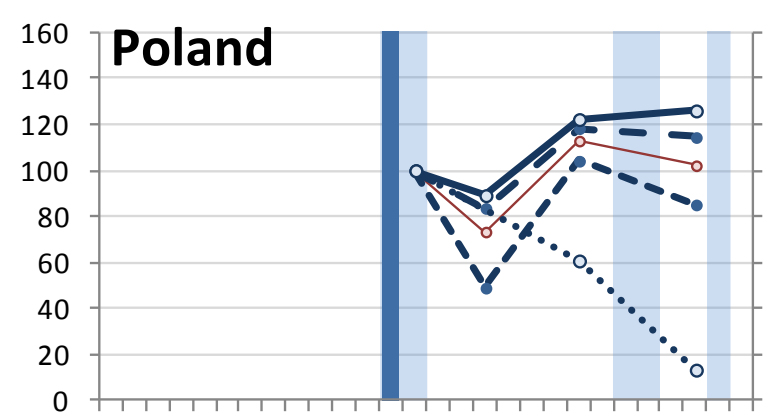

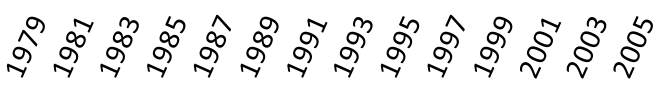

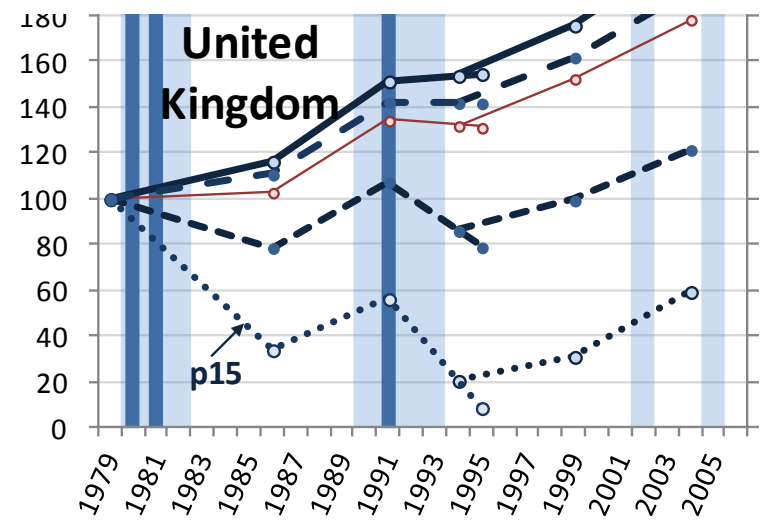

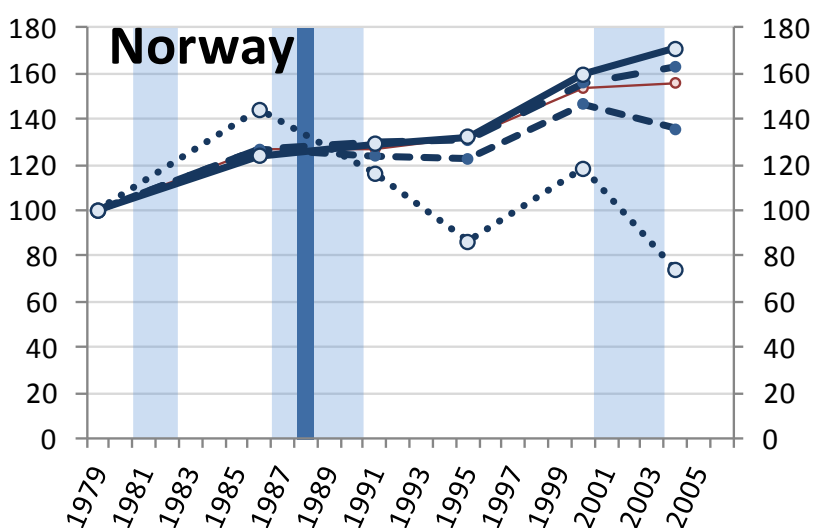

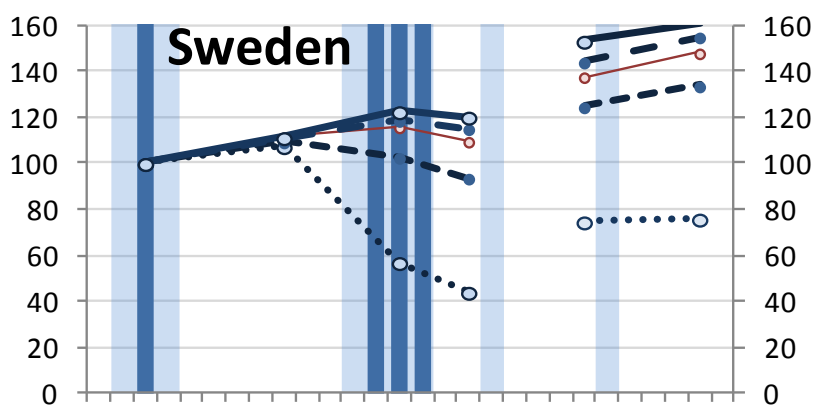

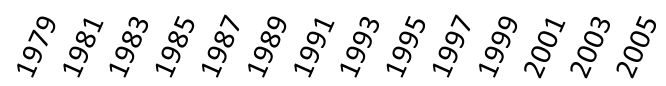

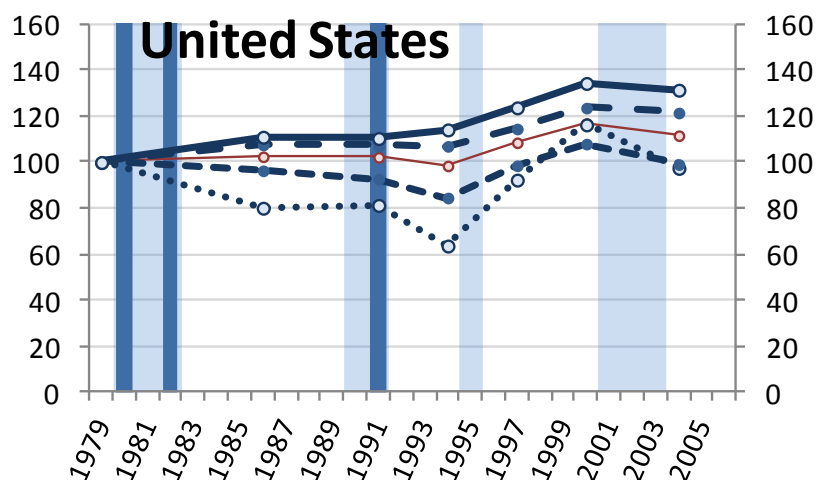

Notes: p10, p25, p50, p75, p90: $10^{\text {th }}, 25^{\text {th }}, 50^{\text {th }}, 75^{\text {th }}$ and $90^{\text {th }}$ percentile of the distribution of household market incomes (or as indicated). Equivalised household incomes using the square-root scale. Separate series indicate a change in underlying data sources (see also Table 4). Market income includes private transfers. Growth data are based on annual GDP. "Low" growth periods are the bottom-third growth years during 1979-2005 in each country. The use of statistical data for Israel by the OECD is without prejudice to the status of the Golan Heights, East Jerusalem and Israeli settlements in the West Bank under the terms of international law.

Sources: Authors' calculations using data from the Luxembourg Income Study and OECD Economic Outlook database (growth data). 
Table 1. Employment / population ratios

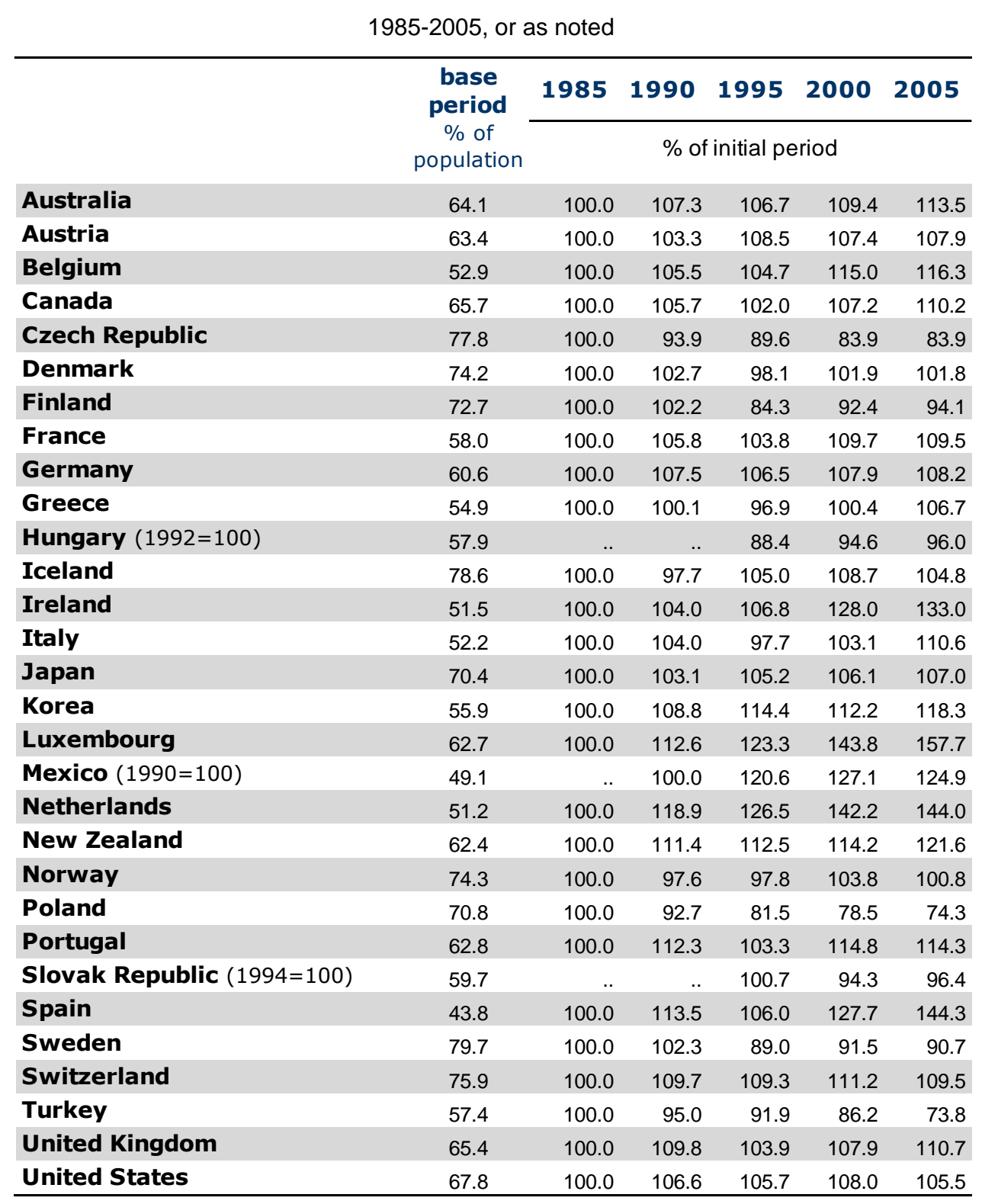

Notes: Employment in percent of working-age population (15-64). Highlighted cells denote series breaks.

Source: OECD Labour Force Statistics. 
DELSA/ELSA/WD/SEM(2011)7

Table 2. Average market incomes for different income groups

Household incomes in constant prices. Earliest available data point $=100$.

\begin{tabular}{|c|c|c|c|c|c|c|c|c|c|c|}
\hline \multirow[b]{3}{*}{ Australia } & \multicolumn{5}{|c|}{ bottom $20 \%$} & \multicolumn{5}{|c|}{ top $20 \%$} \\
\hline & \multicolumn{5}{|c|}{ mid-80s ca. 1990 mid-90s ca. 2000 mid-00s } & \multirow{2}{*}{\multicolumn{2}{|c|}{ mid-80s ca. 1990}} & \multicolumn{3}{|c|}{ mid-90s ca. 2000 mid-00s } \\
\hline & & & 100 & 101 & 124 & & & 100 & 114 & 116 \\
\hline Canada & 100 & 104 & 83 & 100 & 106 & 100 & 107 & 102 & 125 & 130 \\
\hline Chile & & 100 & 134 & 136 & 173 & & 100 & 137 & 159 & 155 \\
\hline Czech Republic & & & 100 & 99 & 106 & & & 100 & 105 & 114 \\
\hline Denmark & 100 & 89 & 79 & 84 & 84 & 100 & 112 & 117 & 134 & 140 \\
\hline Finland & 100 & & 69 & 89 & 102 & 100 & & 115 & 151 & 183 \\
\hline France & 100 & 117 & 89 & 95 & 104 & 100 & 103 & 90 & 99 & 103 \\
\hline West Germany & 100 & 132 & 123 & & & 100 & 115 & 124 & & \\
\hline Germany & & & 100 & 93 & 72 & & & 100 & 102 & 107 \\
\hline Ireland(1) & 100 & & 132 & 273 & & 100 & & 119 & 152 & \\
\hline Ireland(2) & & & & & 245 & & & & & 195 \\
\hline Israel & 100 & 104 & 119 & 129 & 111 & 100 & 111 & 137 & 161 & 159 \\
\hline Italy(1) & 100 & 104 & 76 & 88 & 92 & 100 & 103 & 115 & & \\
\hline Italy(2) & & & 73 & 84 & 89 & & & 112 & 127 & 139 \\
\hline Japan & 100 & & 99 & & & 100 & & 122 & & \\
\hline Japan & & & 100 & 78 & 77 & & & 144 & 120 & 111 \\
\hline Luxembourg & 100 & & 112 & 131 & 168 & 100 & & 136 & 158 & 210 \\
\hline Netherlands(1) & 100 & 102 & 88 & 119 & & 100 & 115 & 118 & 129 & \\
\hline Netherlands(2) & & & & 119 & 112 & & & & 148 & 149 \\
\hline New Zealand & 100 & 61 & 65 & 75 & 77 & 100 & 103 & 111 & 122 & 125 \\
\hline Norway & 100 & & 69 & 101 & 100 & 100 & & 111 & 155 & 176 \\
\hline Portugal(1) & & 100 & 139 & 187 & & & 100 & 151 & 198 & \\
\hline Portugal(2) & & & & & 173 & & & & & 235 \\
\hline Sweden(1) & 100 & 112 & 77 & & & 100 & 125 & 126 & & \\
\hline Sweden(2) & & & 107 & 127 & 132 & & & 128 & 169 & 169 \\
\hline Switzerland & & & & 100 & 98 & & & & 100 & 100 \\
\hline United Kingdom(1) & 100 & 118 & 107 & 121 & & 100 & 131 & 129 & 151 & \\
\hline United Kingdom(2) & & & & 129 & 162 & & & & 184 & 186 \\
\hline United States & 100 & 114 & 110 & 126 & 111 & 100 & 117 & 128 & 138 & 139 \\
\hline
\end{tabular}

Notes: Quantile groups refer to the distribution of household disposable incomes (equivalised using the square-root scale). Superscripts indicate breaks in the underlying data series. The statistical data for Israel are supplied by and under the responsibility of the relevant Israeli authorities. The use of such data by the OECD is without prejudice to the status of the Golan Heights, East Jerusalem and Israeli settlements in the West Bank under the terms of international law.

Source: OECD Income Distribution Database.

14. Changes at particular points in the income distribution, such as the $25^{\text {th }}$ and $75^{\text {th }}$ percentile points, are not the same as changes for "low" and "high" income groups as a whole. The reason is that the distribution of incomes within those groups is subject to change as well. For instance, while the $25^{\text {th }}$ percentile point may not change much during a recovery, many of those in the bottom quartile group may succeed at moving up towards the cut-off points, resulting in rising income averages for the group as a whole. Differences between trends in percentile points and income averages can be expected to be particularly pronounced during periods with significant changes in the number of households with zero market incomes.

15. To document changes in average incomes, Table 2 provides an alternative perspective on the evolution of market incomes over time. Using data from the OECD Income Distribution Database for a larger group of countries, the table shows market-income averages for the bottom and top 20\% (the bottom and top quintile groups). ${ }^{8}$ Results are mostly in line with results from Figure 1 although a few differences

8. Unlike in Figure 1, income information in this data source is ranked by household disposable income, and not by market income, which would be the preferred way of documenting the changing shape of market- 
are notable. When looking at average incomes in the bottom and top quintile groups, there is no longer a narrowing of the market-income distribution in the Netherlands. Similarly, income changes for the "low" income group now appear less beneficial in Denmark, but more so in Australia. Three of the countries not included in Figure 1 saw a narrowing of the gap in average incomes (Chile, France, Ireland), with Chile and Ireland recording very large real-term gains. Average market incomes of the bottom $20 \%$ in Portugal also nearly doubled over the period, but high-income earners there did even better.

\subsubsection{Stated preferences for redistribution}

16. Attitudes towards redistribution are difficult to measure directly, but there are some attitudinal or value surveys that attempt to record respondents' stated preferences. ${ }^{9}$ The World Value Survey is one useful source. It contains a number of questions on attitudes towards inequality, which are formulated in a consistent way across a number of countries and years (see www.worldvaluessurvey.org). Figure 2 shows changes over time in respondents' answers to one such question (they were asked to locate their response on a scale with the two end points "Incomes should be made more equal" and "We need larger income differences as incentives"). While this interview-based indicator is not an ideal measure of redistribution preferences, the figure suggests that only in a few countries did preferences remain relatively unchanged since the late 1980s. ${ }^{10}$ Both the direction and the extent of attitudinal changes vary markedly across countries. This variability underlines the importance of considering the possibility of shifting preferences, particularly in a cross-country comparison of trends in redistribution policies and indicators.

income distributions. For middle and higher income ranges, the difference is likely to be small, as ranking by gross and net incomes can be expected to result in similar groupings. For the bottom quintile, however, the tax-benefit system is likely to result in re-ranking (for instance, a considerable number of households with zero or very low incomes may be entitled to significant amounts of benefits and may therefore not be classified in the low-income group according to household disposable income). Calculations not reported here confirm that, in all of the countries analysed, the extent of re-ranking is greatest at the bottom of the income distribution.

9. Bargain and Keane (2010) use an interesting alternative approach. They derive revealed social preferences by assuming that existing tax and transfer systems are consistent with societal inequality aversion. They find remarkably stable inequality aversion for Ireland over the 1987-2005 period, and large changes for the United Kingdom (becoming less egalitarian during the Thatcher government and more inequality-averse during New Labour). In the context of policy evaluation, the usefulness of such an approach is, however, limited, as it assumes that actual tax and transfer systems in each year are "optimal" and therefore cannot be improved upon by definition.

10. One reason may simply be the quality of the data. For instance, in the context of the present study, one difficulty in interpreting the particular measure used in Figure 2 is that a view that "incomes should be made more (or less) equal" says little about the preferred method for achieving such a change. Some respondents with a preference for reducing inequality may have in mind government redistribution, while others might advocate regulatory measures that would reduce the inequality or volatility of market incomes. It is also not clear whether respondents consider the question in relation to global inequality measures, such as those investigated in this paper, or, say, with respect to income differences between themselves and particular reference groups. 
Figure 2. Across countries, stated preferences show no clear trend towards either less or more redistribution.

Average score on question "should incomes be made more equal" (0-9): Change since late 1980s (1)

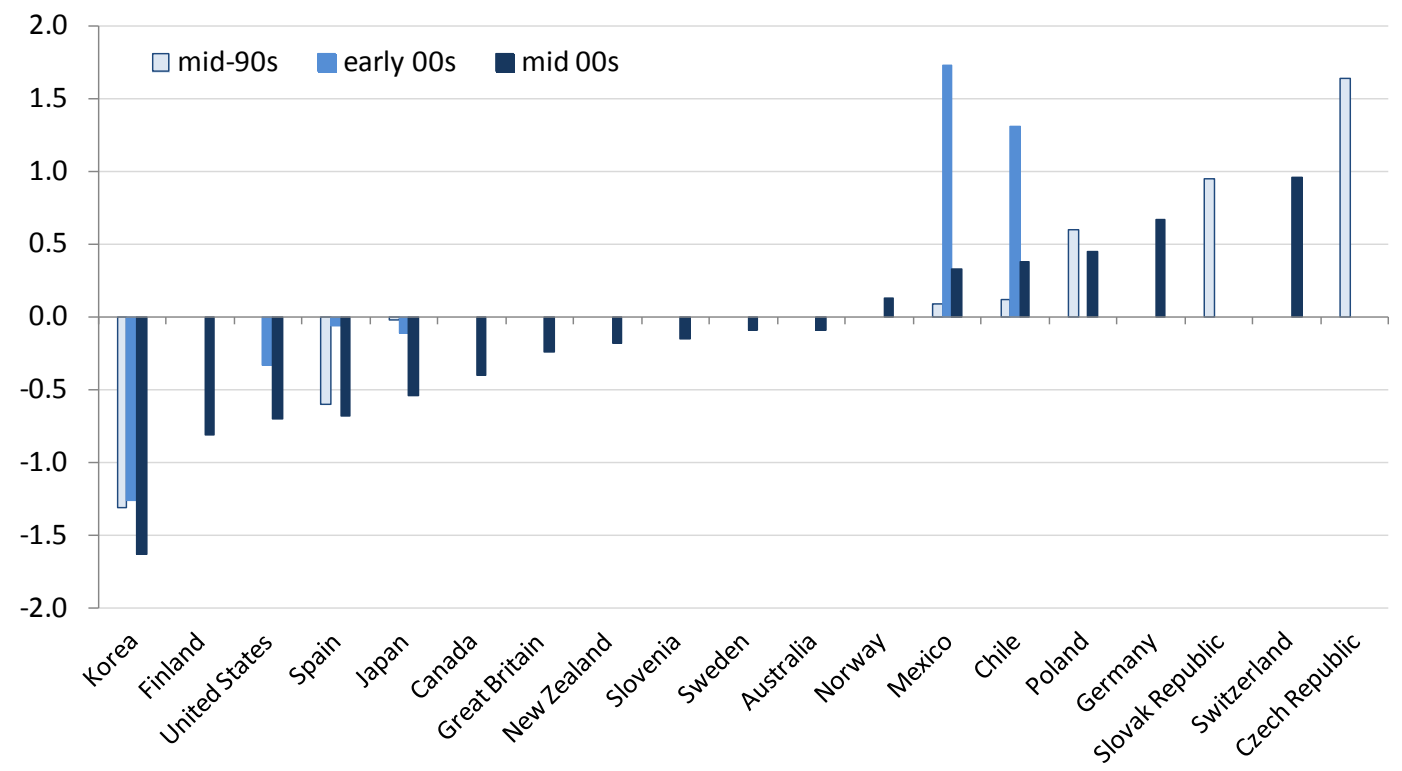

1. For each available period, changes are shown relative to the average score in the late 1980 s, or relative to the earliest year available (early 2000s for Canada, mid-1990s for Finland, Germany, New Zealand, Norway, Slovenia, Sweden, Switzerland, Great Britain and Unites States). Countries are ordered relative to the change since then and up to the latest available period. Respondents were asked to locate their response on a scale with the end points "Incomes should be made more equal" and "We need larger income differences as incentives". For the purpose of this figure, the scores in the original data were inverted so that higher values correspond to "more redistribution". The World Values Survey contains other questions related to redistribution, including one that leads to qualitatively similar trends ("Should government or people take more responsibility?"). Results relate to the entire population, although calculating score averages for working-age people produces very similar trends. The typical number of responses is between 1000 and 1200 for each year and country.

Source: World Value Survey.

17. In combination, the evidence on market-income inequality and attitudes towards redistribution provides a useful basis for speculating whether redistribution is now "more urgent" than 20 years ago. The widening gaps between low-income and high-income groups would indicate that reducing inequalities among working-age households has indeed become a more pressing concern. At the same time, Figure 2 suggests that preferences for reducing inequalities have weakened over the past 20 years or so in just under half of the countries shown (Canada, Finland, United Kingdom and United States). For these countries, it is therefore difficult to conclude whether or not these developments have created a greater need for redistribution. A less ambiguous answer seems possible for the slight majority of countries in Figure 2, where preferences for inequality reduction have either strengthened or remained about the same. For most of these countries (Australia, Czech Republic, Germany, New Zealand, Norway, Poland, and Sweden), both inequality trends and changes in preferences consistently point towards a greater demand for redistribution.

18. As shown in the discussion below, however, country patterns of actual observed changes in redistribution policies are not as clear-cut. One likely reason is that what matters for policy outcomes is not only preferences as such, but how they are expressed and accounted for in the political process. One strand of the political-economy literature focuses explicitly on this process and questions the applicability of the widely used median-voter type models, which assume that each potential voter has equal weight ("one person, one vote"). ${ }^{11}$ If the political influence of different groups is instead determined by their

11. McCarty and Pontusson (2009) review how inequality affects politics and, in turn, redistribution. 
relative incomes ("one dollar, one vote"), then income changes in different parts of the distribution are likely to affect the balance of support for different redistribution measures. For instance, to the extent that growing income polarization strengthens the political influence of the rich, their preferences against redistribution to the poor would carry more weight. So while, with unchanged preferences, increasing inequality would indicate a greater need for redistribution, the political balance may in fact shift towards "rolling back the welfare state", or towards regressive tax changes. ${ }^{12}$

\section{MEASURED CHANGES IN REDISTRIBUTION}

19. Taxes and cash benefits are the most direct policy levers for governments to influence distributional outcomes. Their quantitative importance for household economic well-being is summarised in Figure 3. Income taxes and social contributions paid by working-age households amount to more than $25 \%$ of earned market incomes when averaged across countries. In most countries, average cash benefits received by these households are significantly smaller than average income-tax burdens. Put differently, working-age household are net taxpayers on average. While the group as a whole recoups a considerable portion of their tax payments in the form of cash benefits, the rest goes towards financing other public expenditures, such as publicly provided services, current transfers to the elderly and own future pension entitlements.

20. The extent of interpersonal redistribution is evident from looking at how much is paid and received by different income groups. The poorest $20 \%$ are net benefit recipients in almost all countries, with cash transfers adding up to around two thirds of market income on average. For the richest $20 \%$, benefits are still important in several countries, but represent only $6 \%$ of market incomes on average. As one would expect, the rich also face higher tax burdens, and these are substantially higher than benefits received. Relative to total gross incomes (market income plus transfers), tax burdens are much smaller for low-income groups. But relative to market incomes, cash benefits differ much more across income groups than taxes and are therefore the main drivers of redistribution from rich to poor. Clearly, however, even if tax payments are less redistributive directly, they finance transfers and thus serve a crucial redistributive role.

12. Karabarbounis (2010) uses time-series data for OECD countries to illustrate such a link empirically. See also Schwabish et al. (2006), who investigate the link between inequality in different parts of the distribution on the one hand, and the level of social expenditures for non-elderly benefits on the other. 
Figure 3. Overall amounts of taxes paid and benefits received in the mid-2000s

(a) All households headed by working-age individuals

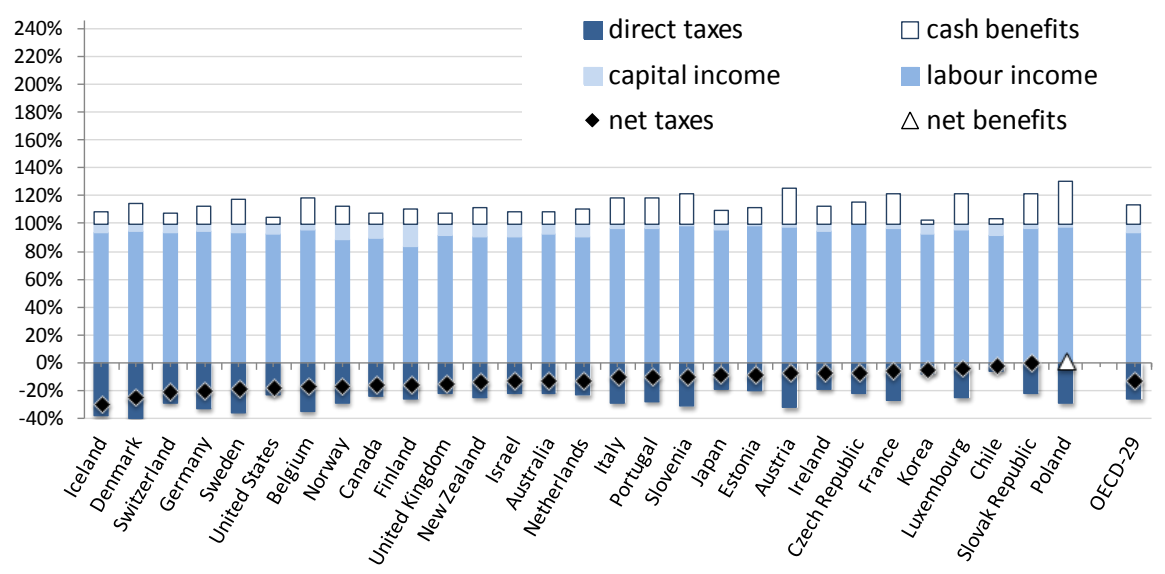

(b) High-income households (top 20\%) headed by working-age individuals

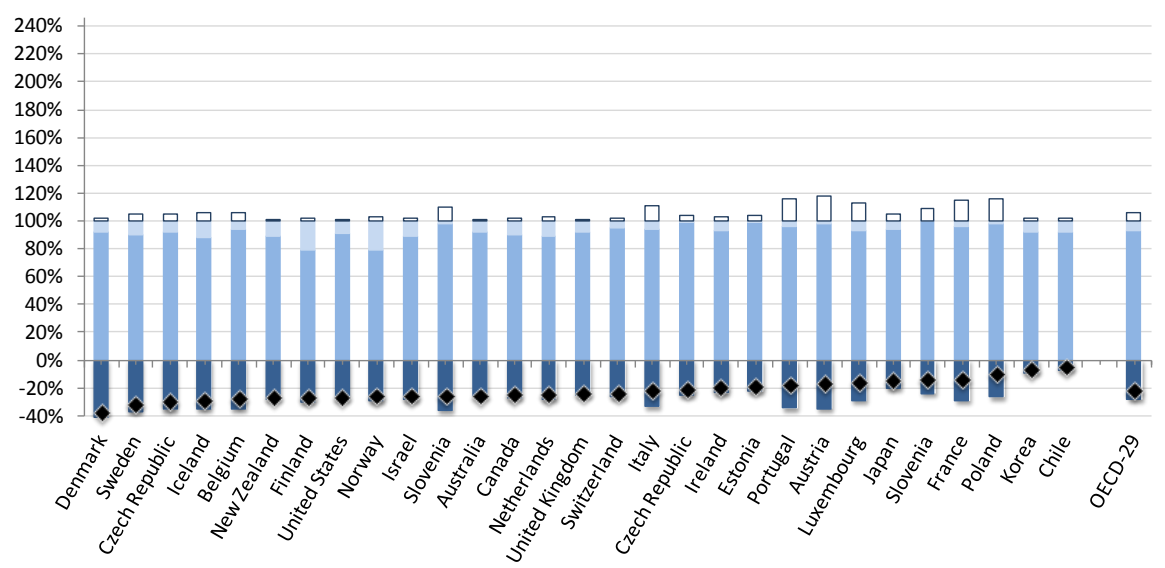

c) Low-income households (bottom $20 \%$ ) headed by working-age individuals

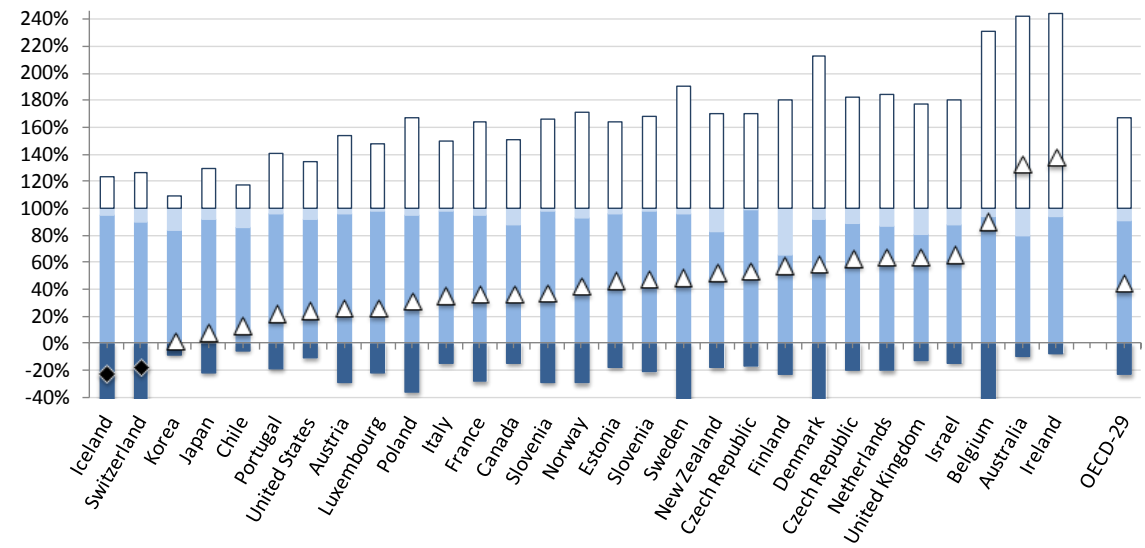

Note: Countries are ranked by the impact of the redistribution system on household income, i.e., by net taxes (taxes minus benefits). Source: OECD income distribution database. 


\subsection{The size of the redistribution system: aggregate expenditures and revenues}

21. Aggregate amounts of transfers taking place between households and governments indicate their effect on total household resources. Looking at the evolution of tax receipts and social expenditures is therefore a useful first step in analysing redistribution trends.

22. Based on data from the OECD Social Expenditure Database, Figure 4 (upper panel) summarises changes in public social expenditure levels using the usual "\% of GDP" format. It is apparent that social expenditure levels have increased markedly in most countries. Across 29 countries with data for all three periods, the average expenditure-to-GDP ratio grew from 16.9 percent of GDP in 1985 to 19.3 percent in 1995 and 20.1 percent in 2005. The only countries with declining public social spending ratios are Chile, Ireland, Netherlands and Sweden. ${ }^{13}$

23. Yet, with this paper's focus on the incomes of the non-elderly population, it is not total expenditure levels, but spending on cash government transfers received by the under-65's, that is of primary interest and provides the link to the analysis of household incomes that follows below. While all public social expenditures serve a redistributive role to some extent, only a minority part of total social spending is in fact devoted to cash benefits with a direct impact on the incomes of the non-elderly.

24. Annex Table A1 shows that, over time, almost all countries devoted declining shares of total spending to cash benefits that mostly benefit children and working-age individuals. ${ }^{14}$ On average the share of these "non-elderly" benefits declined from 26.5 percent in 1985 to 21.4 percent in 2005 (without counting early retirement benefits; the decline is somewhat smaller, but still substantial, when they are included). Despite growing overall public social expenditure, this drop is sufficiently large to translate into a significant reduction of "non-elderly" benefit expenditure relative to GDP on average (from 4.9 to 4.5 percent across 29 countries, upper panel of Figure 4). ${ }^{15}$ Between the mid-80s and the mid-90s, however, sizable reductions were only observed in a few countries (Belgium, France, Ireland, Netherlands) while the majority of countries recorded increases. Most of the drop in "non-elderly" benefit expenditures occurred since the mid-1990s, when most OECD countries recovered from an economic downturn, and spending on cyclical income-support measures was high (and GDP low) as a result (compare the two graphs in the lower panel of Figure 4).

13. Relating public social spending to GDP is not ideal when considering redistribution among households, as the denominator includes all domestic income, i.e., household incomes as well as (national and expatriated) corporate profits. Aggregate statistics on net household income are not always available back to the mid1980s. But, for countries where they are, we have found long-term trends tends to be similar whether expenditure levels are expressed as a percentage of household income, or GDP.

14. Detailed expenditure breakdowns by age are not available. There is therefore only an approximate correspondence between transfers paid to "elderly" and "non-elderly" age groups and the functional classification used in the social expenditure data. In particular, even without counting early retirement benefits, a considerable share of spending on old-age benefits is received by those drawing normal retirement benefits before they reach the age of 65 . At the same time, a part of expenditures shown in the categories "incapacity related", "housing" or "other social policy areas" (which includes social assistance) may provide income support to the elderly.

15. Because the share of early retirement benefits in total social spending has increased over this period, the decline is, again, smaller (from 5.1 to 4.9 percent of GDP) once they are added in. 
Figure 4. Total social expenditure levels increased, but cash transfers for the non-elderly often did not.

Entire period: mid-1980s to mid-2000s, in percent of GDP
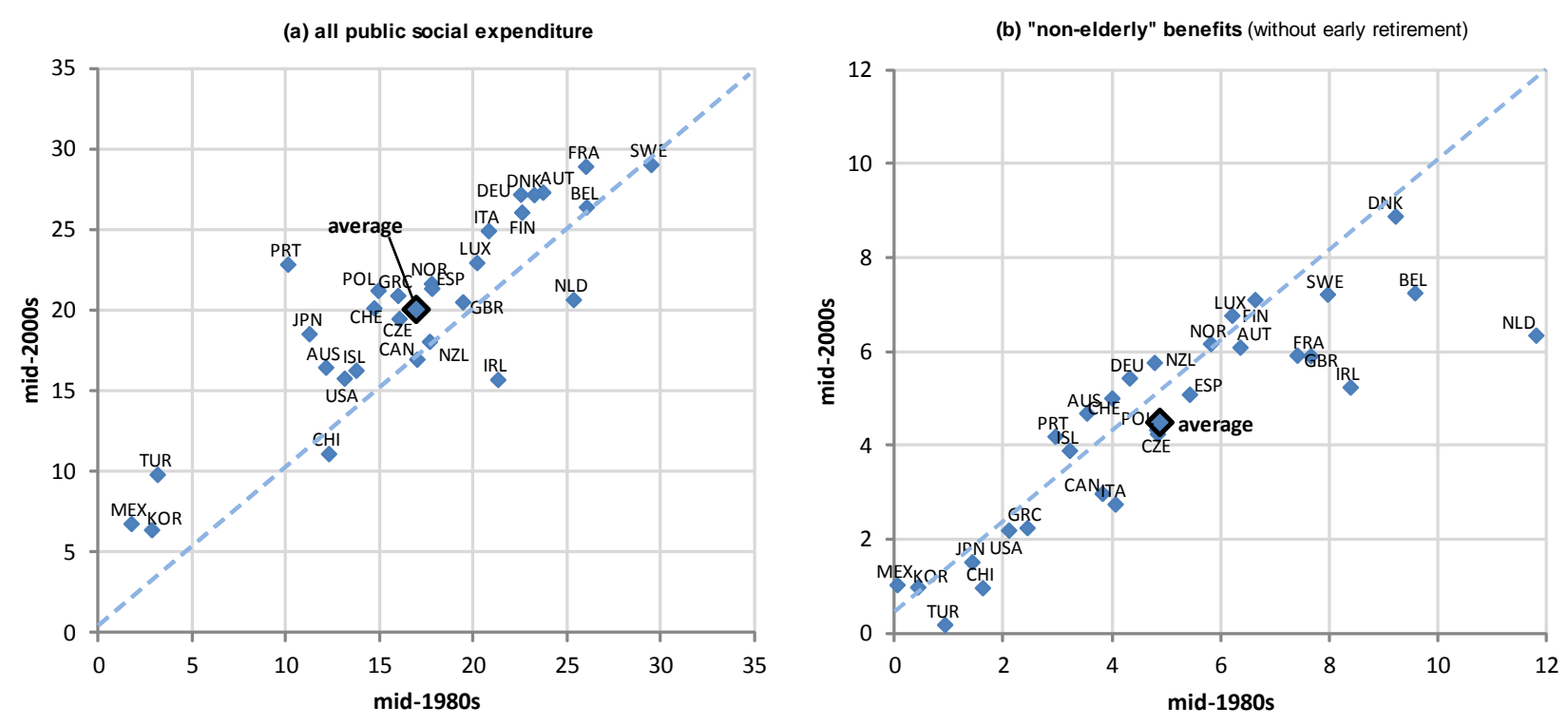

Sub-periods, in percent of GDP

(c) "non-elderly" benefits: mid-80s to mid-90s

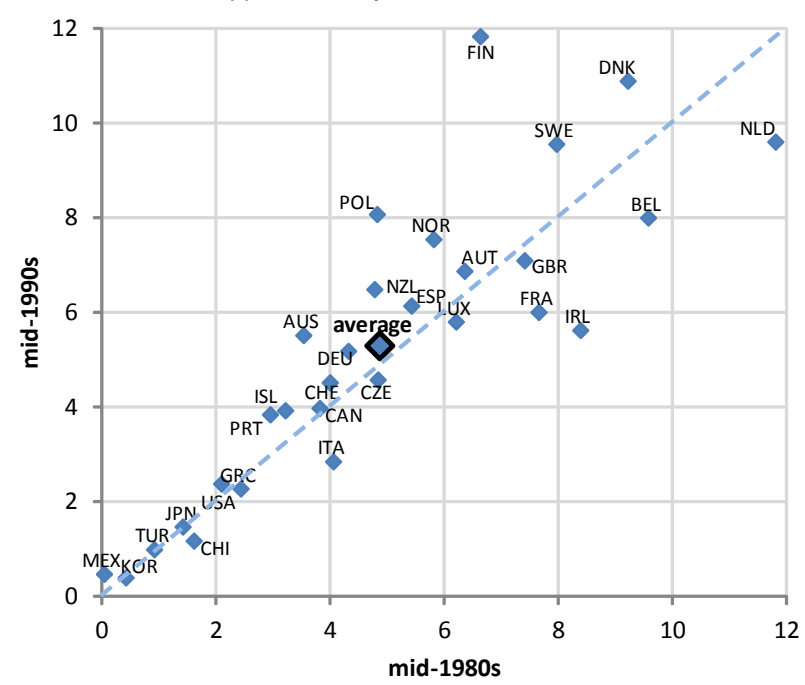

(d) "non-elderly" benefits: mid-90s to mid-00s

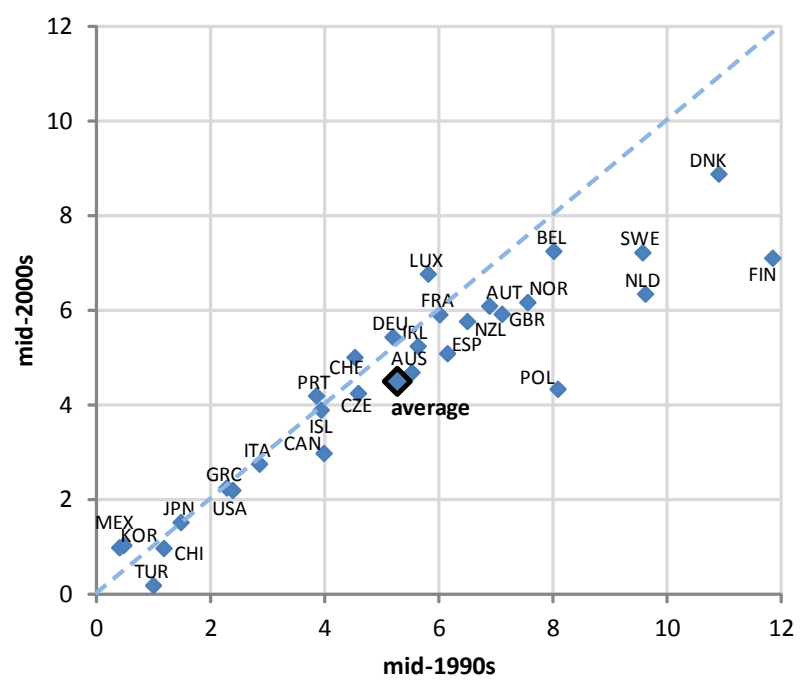

Notes: Annex Table A1 shows the underlying numbers as well as break-downs by spending category. Hungary, Israel, Slovak Republic and Slovenia are not included in the graphs as mid-1980s data are not available for these countries. Mid-1980s data for Germany refer to West Germany.

Source: OECD Social Expenditure Database (www.oecd.org/els/social/expenditure).

25. A closer inspection of the time profile of social expenditure levels can shed light on the relative roles of cyclical and structural factors. Figure 5 confirms that, relative to GDP, total social spending goes up significantly during contractions. It also shows that spending increases can be large during and after deep recessions, such as in Finland or Sweden in the early 1990s, or in Korea in 1998. Interestingly, however, spending on "non-elderly" cash benefits (including early retirement) is less cyclical than one might expect. In about one third of the countries shown, changes in other categories of social spending, including "old-age", "health" and "active labour market programmes", account for a quantitatively bigger 
share of cyclical increases in social spending (Austria, Belgium, Canada, Chile, Israel, Italy, Japan, Korea, Norway, Poland, Portugal). In a number of countries, government spending on cash transfers to workingage individuals and families has remained more or less constant over the entire period (Austria, Czech Republic, France, Germany, Greece, Japan, Korea, Portugal, Spain), despite sometimes sizable trend increases in total spending-to-GDP ratios. As discussed above, public spending on income support for the non-elderly has, relative to GDP, dropped significantly in a few countries.

26. A similar comparison can be made on the revenue side. However, while OECD Revenue Statistics indentify the revenue components that are most relevant in the context of studying income redistribution (personal income taxes and social contributions), it is not possible to approximate the share of these taxes that are paid by "non-elderly" households only. Subject to this caveat, Table 3 shows that, like social expenditures, total government revenues have also increased on average across OECD countries (from 33 percent in the mid 1980s, to 34.7 percent in 1995 and 35.8 percent in 2005). But, unlike in the case of social expenditures, the shares of the total that are typically accounted for in redistribution studies, have gone up as well (from just under 35 percent of total revenues in 1985 to just over 36 percent in 2005). Some of these direct taxes are much more progressive than others. Personal income taxes employ progressive tax schedules (even if they have become flatter, as shown in the next section), while social contributions can be regressive, consuming a bigger part of the incomes of low-to-middle income earners than of higher-income groups. Because their redistributive roles differ significantly, it is important to distinguish the trends for these revenue categories. The personal income tax (PIT) accounts for over a quarter of all revenues. The 20 -year period up to 2005 has seen its share fall somewhat, but since total government revenues have gone up, PIT revenues as a percentage of GDP have remained constant on average across countries (at 8.7\%). In contrast, the share of the less progressive, and possibly regressive, social security contributions (SSC) has increased by more than two percentage points, from 8.1 percent of GDP in 1985 to 10.6 percent in $2005 .{ }^{16}$ Overall, these revenue trends do not point clearly at either more or less redistribution through direct taxes in most countries.

27. A closer inspection of annual revenue statistics since the mid-1980s (not reported here) indicates that PIT revenues are significantly more volatile over the period than SSC. Several countries recorded level changes that persist over longer periods of time (Denmark, France, Portugal, Spain) or notable upwards (Canada and, Iceland, Italy up to early 1990s) or downwards trends (Canada since early 1990s, Germany, Ireland, Japan, Luxembourg, Netherlands, New Zealand up to early 2000s, Poland, Slovak Republic, Sweden). But in several others, total PIT payments have fluctuated without a clear trend in either direction (Australia, Austria, Norway, Switzerland, United Kingdom, United States). With the exception of the Netherlands ${ }^{17}$, changes in total SSC paid by households are smoother and more persistent than for PIT. Because of their flat or regressive rate structure, SSC revenues also vary much less over the economic cycle.

28. Three main other categories of government revenue - indirect taxes, wealth and property taxes, as well as business taxes - are not accounted for in the assessments of income inequality and redistribution below. It is nevertheless interesting to speculate what aggregate trends in these non-income related taxes imply for the relative tax burdens of different income groups. OECD Revenue Statistics data (not reported

16. In roughly one third of OECD countries, SSC paid by employees, self-employed and benefit recipients now account for a similar or higher share of total revenue than the PIT (Czech Republic, Germany, Greece, Japan, Korea, Luxembourg, Mexico, Netherland, Poland, Slovak Republic, Turkey). Among the countries covered in the historical series of the OECD Revenue Statistics Social, mandatory SSC are much lower than income-tax revenues in Canada and the Nordic countries, while they do not exist in Australia and New Zealand.

17. Unlike in other countries, the tax base for a substantial part of SSC in the Netherlands has been similar or identical to the PIT base. As a result, many policy changes affecting PIT also affect SSC liabilities. 
here) show that, among these other taxes, those that tend to be disproportionally borne by higher-income groups (e.g., wealth and property taxes) became less important. Perhaps contrary to common perception, indirect taxes, which consume a greater part of income for lower-income groups, have declined as a share of total tax revenues (from 33.9 percent in 1985 to 31.9 percent in 2005), despite a significant increase in revenues from value-added taxes $(\mathrm{OECD}, 2007 \mathrm{~b})$. Finally, and unlike contributions paid by employees, payroll taxes and social contributions paid by employers have tended to decline slightly between 1985 and 2005. 
DELSA/ELSA/WD/SEM(2011)7

Figure 5. Public social expenditure: total and cash benefits for the non-elderlyln percent of GDP
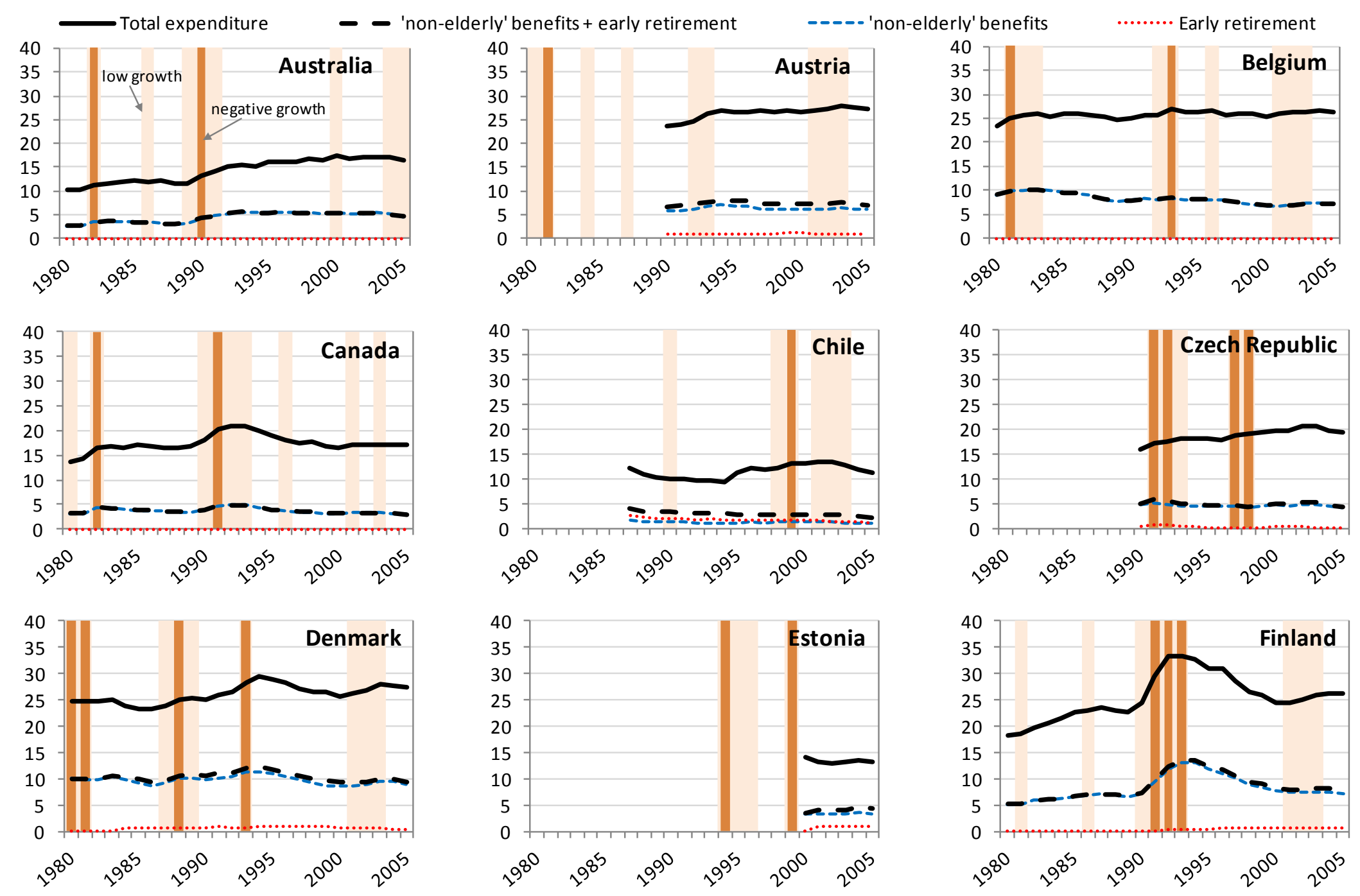
Figure 5 (continued)
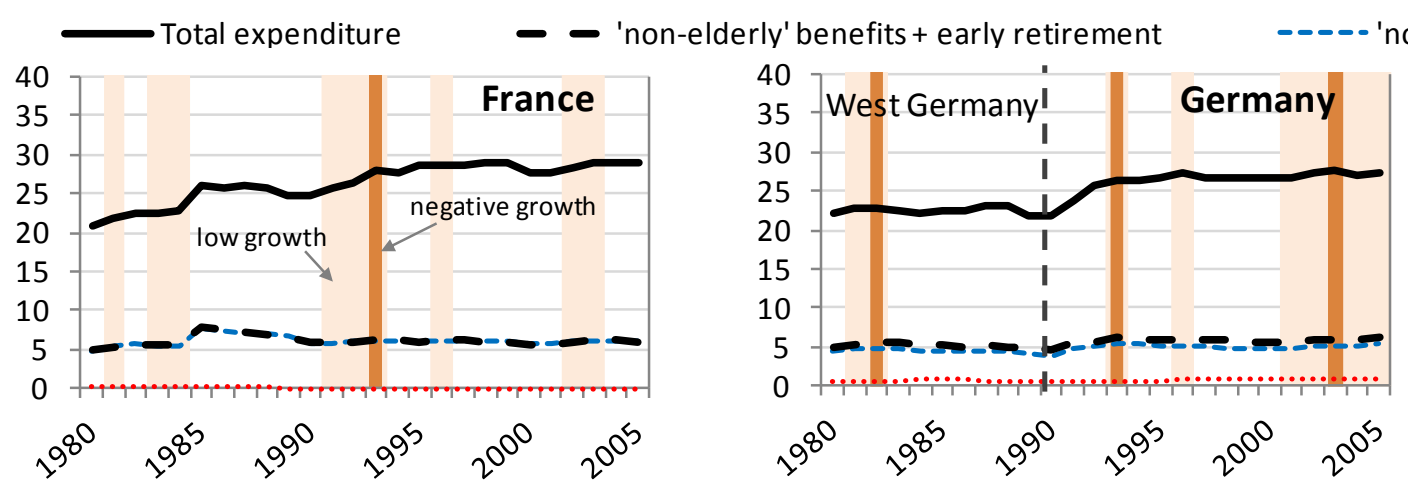

Early retirement
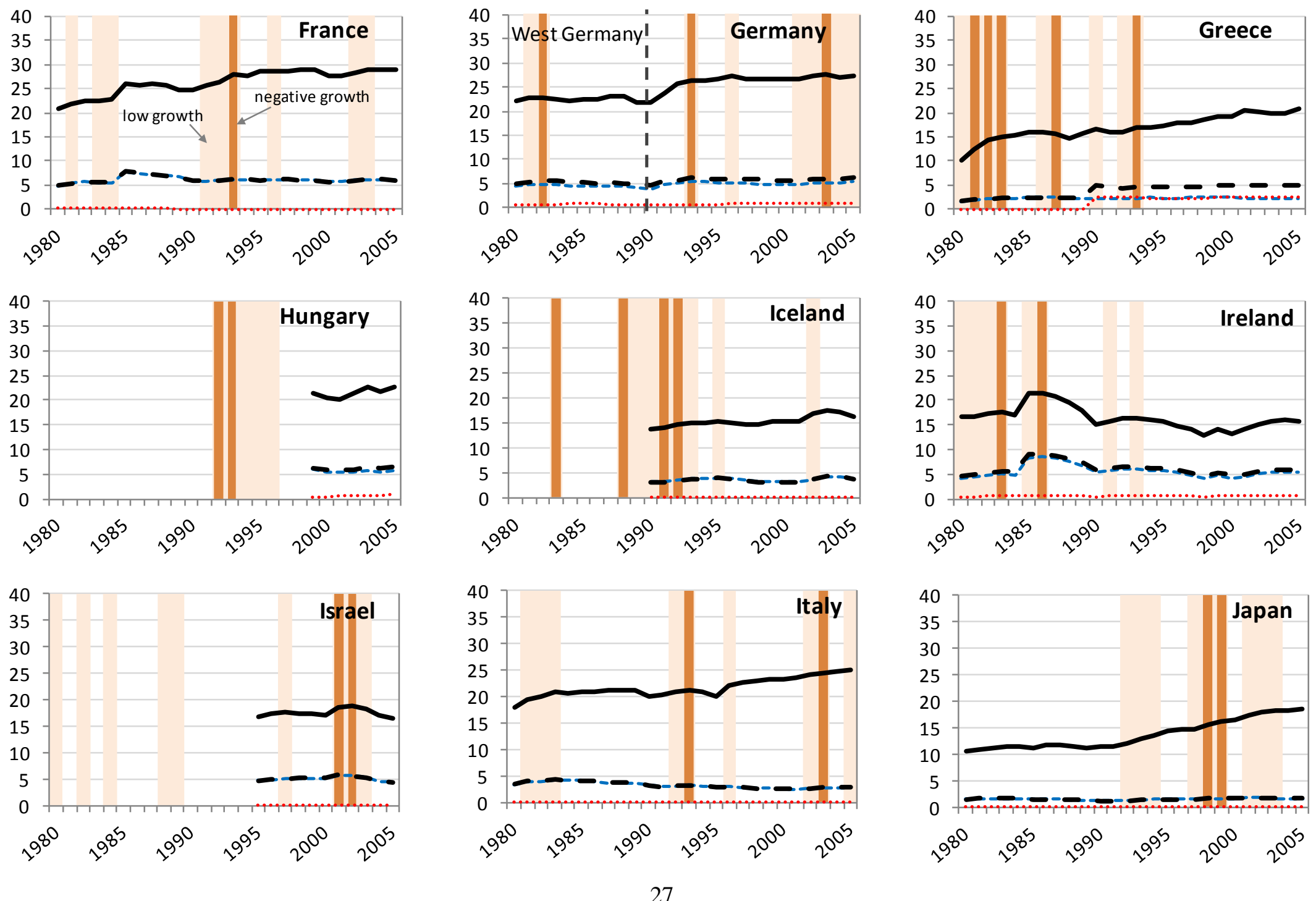

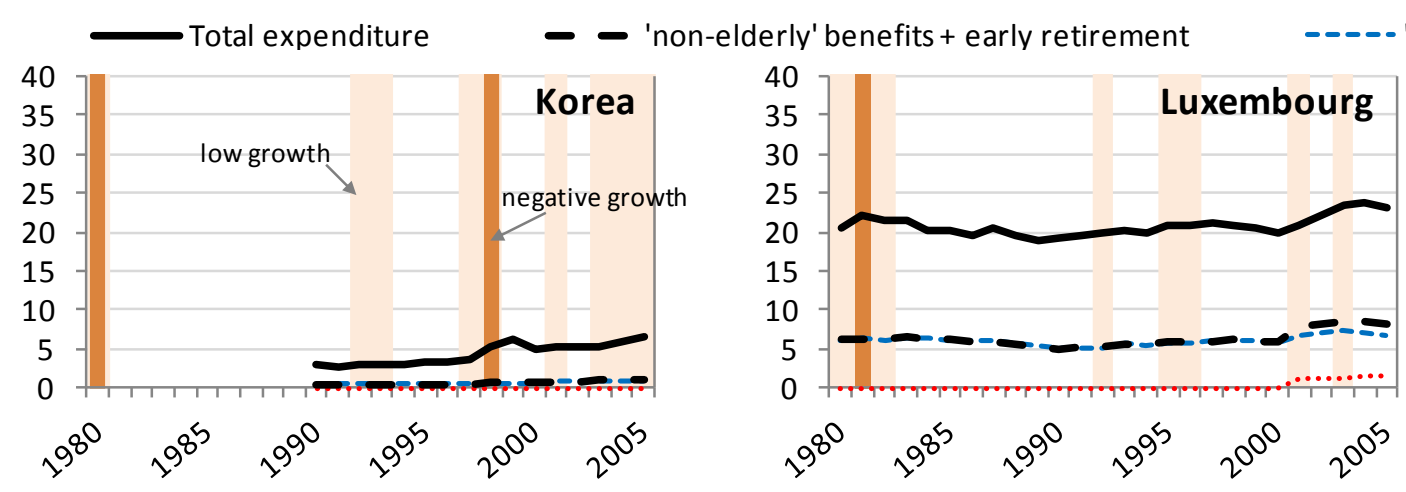

'non-elderly' benefits Early retirement
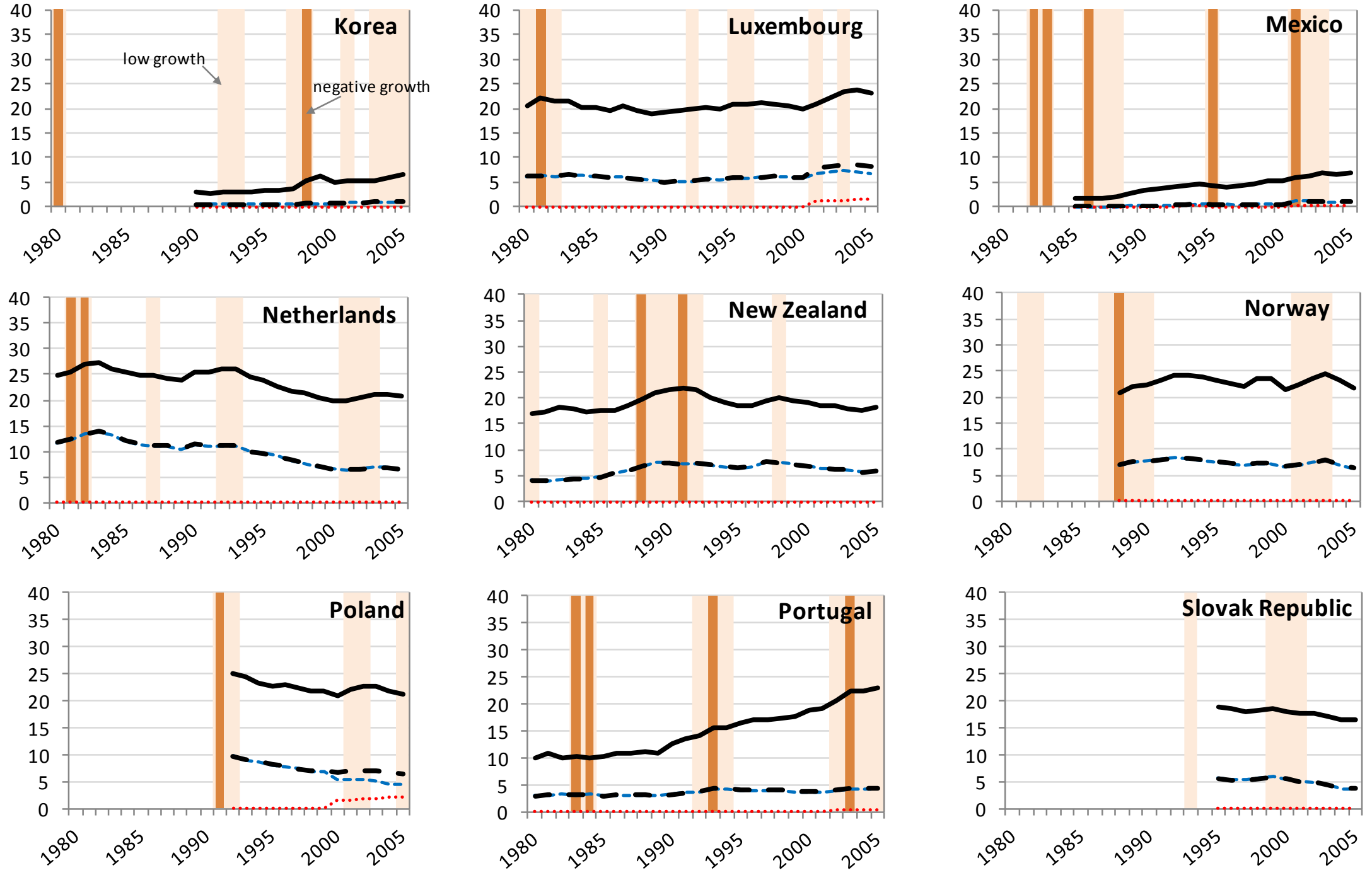
Figure 5 (continued)
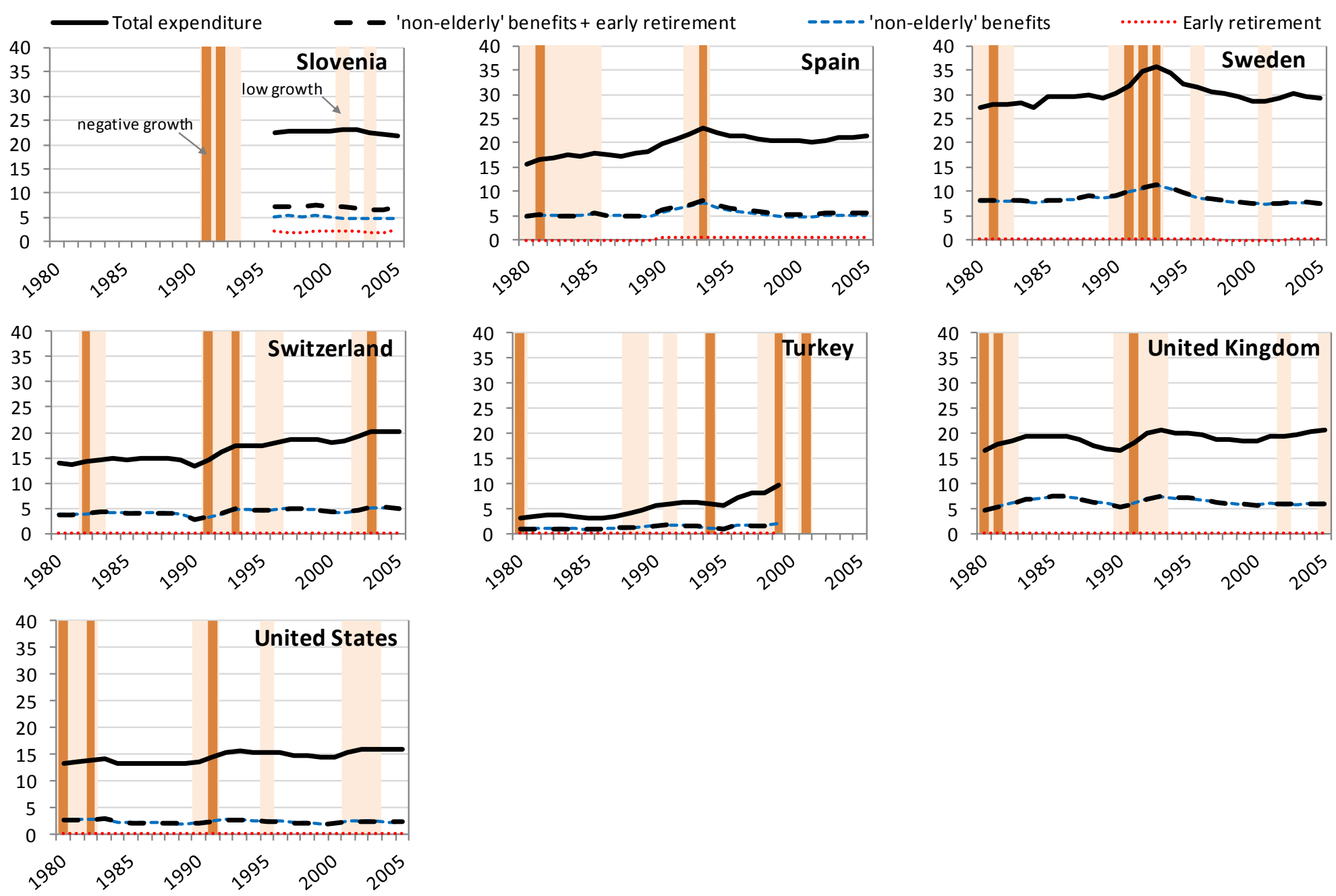

Notes: Growth data are based on annual GDP. "Low" growth periods are the bottom-third growth years during 1979-2005 in each country. The use of statistical data for Israel by the OECD is without prejudice to the status of the Golan Heights, East Jerusalem and Israeli settlements in the West Bank under the terms of international law. 
DELSA/ELSA/WD/SEM(2011)7

Sources: OECD Social Expenditure Database (www.oecd.org/els/social/expenditure) and OECD Economic Outlook database (growth data).

Table 3. Tax revenues: trends and components.

\begin{tabular}{|c|c|c|c|c|c|c|c|c|c|c|c|c|c|c|c|c|}
\hline \multirow{5}{*}{ Australia } & \multicolumn{5}{|c|}{1985} & \multicolumn{5}{|c|}{1995} & \multicolumn{6}{|c|}{2005} \\
\hline & \multirow{3}{*}{$\begin{array}{l}\text { Total } \\
\% \text { of } \\
\text { GDP }\end{array}$} & \multirow{2}{*}{\multicolumn{4}{|c|}{\begin{tabular}{|c|c|}
\multicolumn{2}{|c|}{ Taxes on personal income } \\
\end{tabular}}} & \multirow{3}{*}{$\begin{array}{l}\text { Total } \\
\% \text { of } \\
\text { GDP }\end{array}$} & \multirow{2}{*}{\multicolumn{4}{|c|}{\begin{tabular}{|c|c|}
\multicolumn{3}{|c|}{ Taxes on personal income } \\
\multirow{2}{*}{} & Share of total revenue \\
\cline { 2 - 3 }
\end{tabular}}} & \multirow{3}{*}{$\begin{array}{l}\text { Total } \\
\% \text { of } \\
\text { GDP }\end{array}$} & \multicolumn{5}{|c|}{ Taxes on personal income } \\
\hline & & & & & & & & & & & & \multirow{2}{*}{$\begin{array}{l}\% \text { of } \\
\text { GDP }\end{array}$} & \multicolumn{4}{|c|}{ Share of total revenue } \\
\hline & & GDP & Total & Income tax & $\begin{array}{c}\text { Social } \\
\text { contribution Unallocated }\end{array}$ & & GDP & Total & Income & $\begin{array}{c}\text { Social } \\
\text { contribution Unallocated }\end{array}$ & & & Total & Income tax & $\begin{array}{c}\text { Social } \\
\text { contribution }\end{array}$ & Unallocated \\
\hline & 28.3 & 12.8 & 45.2 & 45.2 & 0.0 & 28.8 & 11.7 & 40.6 & 40.6 & 0.0 & 30.8 & 12.2 & 39.7 & 39.7 & 0.0 & 0.0 \\
\hline Austria & 40.8 & 15.9 & 38.9 & 22.9 & 15.9 & 41.4 & 16.6 & 40.2 & 20.9 & 18.3 & 42.3 & 17.2 & 40.7 & 22.0 & 18.2 & 0.6 \\
\hline Belgium & 44.4 & 21.6 & 48.7 & 35.6 & 13.1 & 43.6 & 19.9 & 45.7 & 32.6 & 13.1 & 44.7 & 19.1 & 42.6 & 30.5 & 12.1 & 0.0 \\
\hline Canada & 32.5 & 13.1 & 40.4 & 35.2 & 4.8 & 35.6 & 15.4 & 43.4 & 37.5 & 0.4 & 33.4 & 14.3 & 42.7 & 35.6 & 6.5 & 0.7 \\
\hline Czech Republic & 40.4 & 3.6 & 8.9 & 8.9 & 0.0 & 37.5 & 10.2 & 27.2 & 12.8 & 14.4 & 37.6 & 10.4 & 27.7 & 12.2 & 15.5 & 0.0 \\
\hline Denmark & 46.1 & 24.7 & 53.5 & 50.7 & 1.7 & 48.8 & 28.1 & 57.6 & 53.8 & 1.6 & 50.8 & 27.1 & 53.4 & 49.0 & 2.1 & 2.3 \\
\hline Finland & 39.7 & 16.9 & 42.7 & 37.4 & 5.3 & 45.7 & 18.4 & 40.3 & 31.1 & 0.0 & 44.0 & 16.5 & 37.6 & 30.7 & 6.9 & 0.0 \\
\hline France & 42.8 & 11.5 & 26.8 & 11.5 & 15.3 & 42.9 & 12.0 & 28.0 & 11.4 & 16.6 & 43.9 & 13.2 & 30.0 & 18.0 & 12.0 & 0.0 \\
\hline Germany & 36.1 & 16.7 & 46.3 & 28.7 & 17.6 & 37.2 & 17.5 & 47.1 & 27.5 & 19.6 & 34.8 & 15.3 & 44.0 & 23.3 & 20.7 & 0.0 \\
\hline Greece & 25.5 & 8.5 & 33.4 & 13.9 & 15.8 & 28.9 & 9.1 & 31.6 & 12.0 & 17.6 & 31.4 & 10.7 & 34.1 & 14.6 & 19.3 & 0.2 \\
\hline Hungary & 45.2 & 10.4 & 23.0 & 14.8 & 6.9 & 41.3 & 9.6 & 23.2 & 16.1 & 0.2 & 37.3 & 9.2 & 24.5 & 18.0 & 6.3 & 0.3 \\
\hline Iceland & 28.2 & 5.5 & 19.7 & 19.5 & 0.2 & 31.2 & 9.8 & 31.5 & 31.1 & 0.0 & 40.6 & 17.0 & 41.8 & 34.8 & 0.0 & 7.0 \\
\hline Ireland & 34.7 & 12.7 & 36.6 & 31.3 & 5.3 & 32.5 & 11.8 & 36.2 & 30.7 & 0.0 & 30.4 & 10.0 & 33.1 & 27.3 & 5.8 & 0.0 \\
\hline Italy & 33.6 & 12.5 & 37.1 & 26.7 & 9.9 & 40.1 & 14.9 & 37.1 & 26.0 & 10.7 & 40.8 & 14.1 & 34.5 & 25.5 & 9.4 & -0.4 \\
\hline Japan & 27.4 & 10.8 & 39.6 & 24.7 & 14.8 & 26.8 & 10.7 & 39.8 & 22.4 & 17.5 & 27.4 & 10.5 & 38.4 & 18.3 & 20.1 & 0.0 \\
\hline Korea & 15.7 & 2.2 & 14.2 & 13.4 & 0.0 & 18.6 & 4.0 & 21.3 & 19.2 & 0.2 & 23.9 & 6.1 & 25.4 & 13.3 & 12.1 & 0.0 \\
\hline Luxembourg & 39.4 & 15.3 & 38.9 & 25.6 & 13.4 & 37.1 & 13.3 & 35.9 & 21.7 & 14.2 & 37.6 & 13.0 & 34.7 & 19.0 & 15.7 & 0.0 \\
\hline Mexico & 15.5 & 2.9 & 18.6 & 0.0 & 18.6 & 15.2 & 3.6 & 23.5 & 0.0 & 23.5 & 18.1 & 4.1 & 22.5 & 0.0 & 0.0 & 22.5 \\
\hline Netherlands & 42.4 & 19.5 & 45.9 & 19.4 & 26.5 & 41.5 & 22.5 & 54.1 & 18.9 & 35.2 & 38.5 & 15.9 & 41.2 & 18.0 & 23.2 & 0.0 \\
\hline New Zealand & 31.3 & 19.0 & 60.8 & 60.5 & 0.0 & 36.6 & 17.3 & 47.2 & 45.0 & 2.2 & 37.4 & 16.3 & 43.6 & 41.1 & 0.0 & 2.6 \\
\hline Norway & 42.6 & 12.3 & 28.9 & 22.5 & 6.4 & 40.9 & 14.5 & 35.6 & 25.9 & 0.0 & 43.5 & 13.2 & 30.3 & 22.2 & 8.1 & 0.0 \\
\hline Poland & 34.9 & 7.1 & 20.2 & 20.2 & 0.0 & 36.2 & 8.3 & 22.9 & 22.9 & 0.0 & 33.0 & 11.3 & 34.3 & 11.9 & 22.4 & 0.0 \\
\hline Portugal & 25.2 & 6.0 & 23.8 & 0.0 & 13.1 & 32.1 & 9.1 & 28.4 & 17.3 & 11.1 & 34.7 & 9.4 & 27.2 & 15.6 & 11.6 & 0.0 \\
\hline Slovak Republic & & & & & & 36.7 & 10.0 & 27.3 & 11.8 & 14.2 & 31.4 & 8.4 & 26.8 & 8.4 & 18.0 & 0.4 \\
\hline Spain & 27.6 & 8.2 & 29.7 & 19.4 & 10.1 & 32.1 & 11.2 & 34.8 & 23.6 & 11.2 & 35.7 & 9.7 & 27.2 & 17.9 & 9.0 & 0.3 \\
\hline Sweden & 47.4 & 18.9 & 39.9 & 38.7 & 1.1 & 47.5 & 17.8 & 37.4 & 33.5 & 0.0 & 49.5 & 18.5 & 37.4 & 31.6 & 6.0 & -0.1 \\
\hline Switzerland & 25.5 & 13.2 & 51.7 & 39.2 & 12.4 & 27.7 & 14.1 & 51.0 & 36.3 & 14.7 & 29.2 & 14.2 & 48.8 & 35.7 & 13.1 & 0.0 \\
\hline Turkey & 11.5 & 3.8 & 33.5 & 27.5 & 6.0 & 16.8 & 4.6 & 27.4 & 21.6 & 0.0 & 24.3 & 6.5 & 26.9 & 14.7 & 12.2 & 0.0 \\
\hline United Kingdom & 37.0 & 12.9 & 34.8 & 26.0 & -0.2 & 34.0 & 12.6 & 36.9 & 28.8 & 0.0 & 35.8 & 13.5 & 37.6 & 29.1 & 8.5 & 0.0 \\
\hline United States & 25.6 & 12.6 & 49.3 & 37.8 & 11.5 & 27.9 & 13.3 & 47.9 & 35.8 & 12.1 & 27.5 & 12.9 & 47.0 & 35.1 & 11.9 & 0.0 \\
\hline Unweighted average & 33.3 & 12.1 & 35.5 & 26.1 & 1.4 & 34.7 & 13.2 & 37.0 & 26.1 & 1.1 & 35.8 & 13.2 & 36.2 & 24.3 & 10.6 & 1.2 \\
\hline
\end{tabular}

Note: Social contributions refer to the amounts paid by households only.

Source: OECD Revenue Statistics. 
DELSA/ELSA/WD/SEM(2011)7

\subsection{Changes in the extent of redistribution: some evidence from household income data}

29. This section uses a range of Gini-based inequality measures to summarise changes in redistribution over time.

\subsubsection{Redistribution in the tax-benefit systems as a whole}

30. Figure 7 and Tables 4 and 5 show inequality trends for market, or private, incomes $\left(G_{m}\right.$, including any private transfers) and disposable incomes ( $G_{d}$, market incomes plus cash benefits minus income taxes). As a global inequality measure, the Gini coefficient accounts for income differentials in all parts of the distribution. It can therefore give different answers about trends than a plot of income values at specific points in the distribution. The overall trends towards greater market-income inequality are nevertheless broadly consistent with those indicated earlier in Figure 1: Over the periods considered, market incomes in "working-age" households have become more unequal everywhere except in the Netherlands and Switzerland. ${ }^{18}$

31. In most cases, market-income inequality has risen more strongly during the first half of the two decades between the mid-80s and the mid-2000s. In addition, most of the countries with data going back further have seen large increases in market-income Ginis before the mid-80s (the United Kingdom, where it rose by almost 10 points between 1979 and 1986, stands out in this respect). Only the data for West Germany show a greater increase in market-income inequalities during the mid-90s to mid-2000s.

32. As the time periods covered by the data vary across countries, it is informative to relate observed changes to a common time interval. Using the data reported in Table 5 (column 2), averaging across years, and extrapolating trends for countries where available data cover only a short period, it can be shown that the Gini coefficient for market income has, on average, increased by $16 \%$ over a ten-year period across the countries shown. This is a very substantial increase over a relatively short period of time. For instance, and as discussed below, $16 \%$ is the same order of magnitude as the reduction in inequality among the nonelderly population that is achieved by the entire tax-benefit system in some countries (e.g., Switzerland or the United States). Given these large changes, market-income inequality has been the main driver of inequality trends in disposable incomes. ${ }^{19}$ But redistribution policies had a substantial effect as well, especially since the mid-1990s.

33. The difference between the Gini values for market incomes and disposable incomes is a measure of the overall redistributive (or equalising) effect of taxes and transfers (vertical distance between the dashed and the solid lines in Figure 7 and column 4 in Tables 4 and 5). On average across countries for which the necessary data are available, inequality increased both before and after taxes and transfers (Table 4). Between the mid-80s and the mid-90s, redistribution systems compensated nearly three quarters of the (sizable) increase in market-income inequality (column 7). The upwards trend in market-income inequality then continued after the mid-90s, but at a much slower pace.

18. In Switzerland the subsequent equalising impact on the distribution of disposable income was further reinforced by a trend towards more redistribution.

19. Market-income inequality has also been the main determinant of differences across countries. For instance, in the early-mid 2000s, the English-speaking countries, Israel and Poland ranked highest in terms of the inequality indicators of both market and disposable income. That countries with the highest marketincome inequality are also those with the highest inequality in disposable income is worth noting. While a dominant role of market-income inequality might be intuitive, it is in contrast with findings reported in studies that include the elderly population. For instance, Jesuit and Mahler (2004) note that some of the countries with the highest disposable-income Ginis have below-average market-income inequality. 
34. Yet, inequality of household disposable income (column 3) rose more quickly in the second decade. Although the rise in market-income inequality slowed significantly, government redistribution became less effective at offsetting growing inequalities. In absolute terms, redistribution weakened (column 4) despite a continuing widening of the market-income distribution (column 1). Over the two decades as a whole, market-income inequality rose by about twice as much as redistribution (column 7). Taxes and transfers now lower inequality by about $29 \%$ (column 5); more than in the mid-80s, but less than in the mid-90s.

Table 4. Redistribution: General country trend

Inequality before and after taxes and transfers ${ }^{1}$

Countries with full tax benefit information for mid-80s, mid-90s and mid-00s ${ }^{2}$

\begin{tabular}{|c|c|c|c|c|c|c|c|c|}
\hline & & \multicolumn{2}{|c|}{ market income } & \multirow{2}{*}{$\begin{array}{c}\text { disposable } \\
\text { income } \\
G_{d}\end{array}$} & \multicolumn{4}{|c|}{ redistribution } \\
\hline & & $\mathrm{G}_{\mathrm{m}}$ & $\begin{array}{c}\text { change, } \% \text { of } \\
\text { base period }\end{array}$ & & $G_{m}-G_{d}$ & $\begin{array}{c}\% \text { of } G_{m} \\
{[4] /[1]}\end{array}$ & $\begin{array}{c}\text { change, } \% \text { of } \\
\text { base-period } G_{m}\end{array}$ & {$[6] /[2]$} \\
\hline & & [1] & [2] & [3] & [4] & [5] & [6] & [7] \\
\hline \multirow{3}{*}{$\begin{array}{c}\text { 12-country } \\
\text { average }\end{array}$} & mid-80s & 36.2 & & 26.7 & 9.5 & 26.4 & & \\
\hline & mid-90s & 39.2 & 8.2 & 27.4 & 11.7 & 29.9 & 6 & 73 \\
\hline & mid-00s & 39.8 & 9.8 & 28.3 & 11.4 & 28.7 & 5 & 53 \\
\hline
\end{tabular}

1. Households headed by a working-age individual (15-64, except in Sweden where 25 was chosen as the age cut-off in order to minimise the impact of a change in the definition of a household that occurred in the mid-90s). Gini values (G) are shown in percent. All measures are based on equivalised household income using the square-root equivalence scale and weighting each household by its size. Market income includes private transfers. Disposable income is market income plus cash government transfers minus income taxes minus social security contributions paid by households. Common LIS practice was followed to limit comparability issues across years and countries at the top and bottom of the distribution: Household incomes were top-coded at 10 times the (non-equivalised) median, and bottom-coded at $1 \%$ of the (equivalised) median (see www.lisproject.org).

2. Australia, Canada, Denmark, Finland, West Germany, Israel, Netherlands, Norway, Sweden, Switzerland, United Kingdom, United States.

Source: Authors' calculations based on the Luxembourg Income Study (LIS).

35. Similar results for each country are presented in Table 5. Among the countries shown, taxbenefit systems in the Nordic countries, the Czech Republic and Poland achieve the greatest reduction in inequality, lowering the Gini value by 13 points or more in the mid-2000s (Table 5 shows that this corresponds to about $40 \%$ of market-income inequality in Denmark, Finland and Sweden, and a third or less in the other countries), while the smallest redistributive effect is seen in Switzerland (5.5 points, or $18 \%)$, United States $(8.1,18 \%)$ and Canada $(8.8,22 \%)$.

36. When market-income inequalities change substantially, full compensation through redistribution is often unrealistic and probably not a useful benchmark for redistribution policies. Nonetheless, the country results for the decade from the mid-80s to the mid-90s demonstrate that it is possible for taxbenefit systems to be quite effective at stabilising inequality even during periods of rapidly growing market-income disparities. The extent of inequality cushioning was strongest in Canada, Denmark, Finland and Sweden, where trends towards more extensive government redistribution offset more than $70 \%$ of the rise in market-income inequality up until the mid-90s. In Denmark, redistribution increased twice as much as market-income inequality (in terms of Gini points, the increase was comparable to that of the other countries in this group, but in Demark this occurred in the context of a much slower growth in market-income inequality). In line with the country average, redistribution in these countries has become less effective at countering growing earnings gaps since then (column 7). For instance, in Finland, greater equalisation through taxes and benefits offset more than three quarters of the $23 \%$ increase in marketincome inequality up until 1995 , but by 2004 , this has dropped to $50 \%$. In a majority of the countries shown in Table 5, redistribution has declined since the mid-1990s - in absolute terms (column 4) and often 
more strongly as a percentage of the market-income Gini (column 5). Tax-benefit systems in a few countries (Canada, Finland, Israel) have become less redistributive since the mid-1990s, despite a continuing rise in market-income inequality.

37. In Germany, where unemployment was high in the mid-90s and in the mid-2000s, the tax-benefit system became more redistributive since. The same is true in Norway, although the accelerating growth in market-income inequality nevertheless resulted in a less equal distribution of disposable income. In the United States, the Gini coefficient for market incomes rose by eight points between the late 1970s and the mid-2000s, but redistribution increased only very slightly, offsetting less than one tenth of this increase $(2 / 21=9 \%)$. In Israel and the United Kingdom, two of the other countries with data going back to the late 1970s, changes in tax and benefit payments also compensated only a small part of the increase in marketincome inequality over the period as a whole, but with large variations in-between.

38. Due to data limitations, English-speaking countries and Northern Europe are overrepresented in the data discussed so far. Panel (b) of Figure 7 reports results for a number of countries for which LIS data record market incomes only on an after-tax basis. Since information on income taxes and social contributions is not available in these cases, a full analysis of the extent of government redistribution is not possible. It is nevertheless interesting to compare inequality trends between (after-tax) market incomes and household disposable incomes. The differences between the two show to what extent government transfers alone can reduce inequality in these countries. Without accounting for taxes, the broad result of rising inequalities despite more government redistribution holds for these countries as well. Only in Austria have benefits become sufficiently redistributive to more than offset the greater inequality in aftertax incomes. 
Table 5. Redistribution trends: Detailed results by country

Inequality before and after taxes and transfers

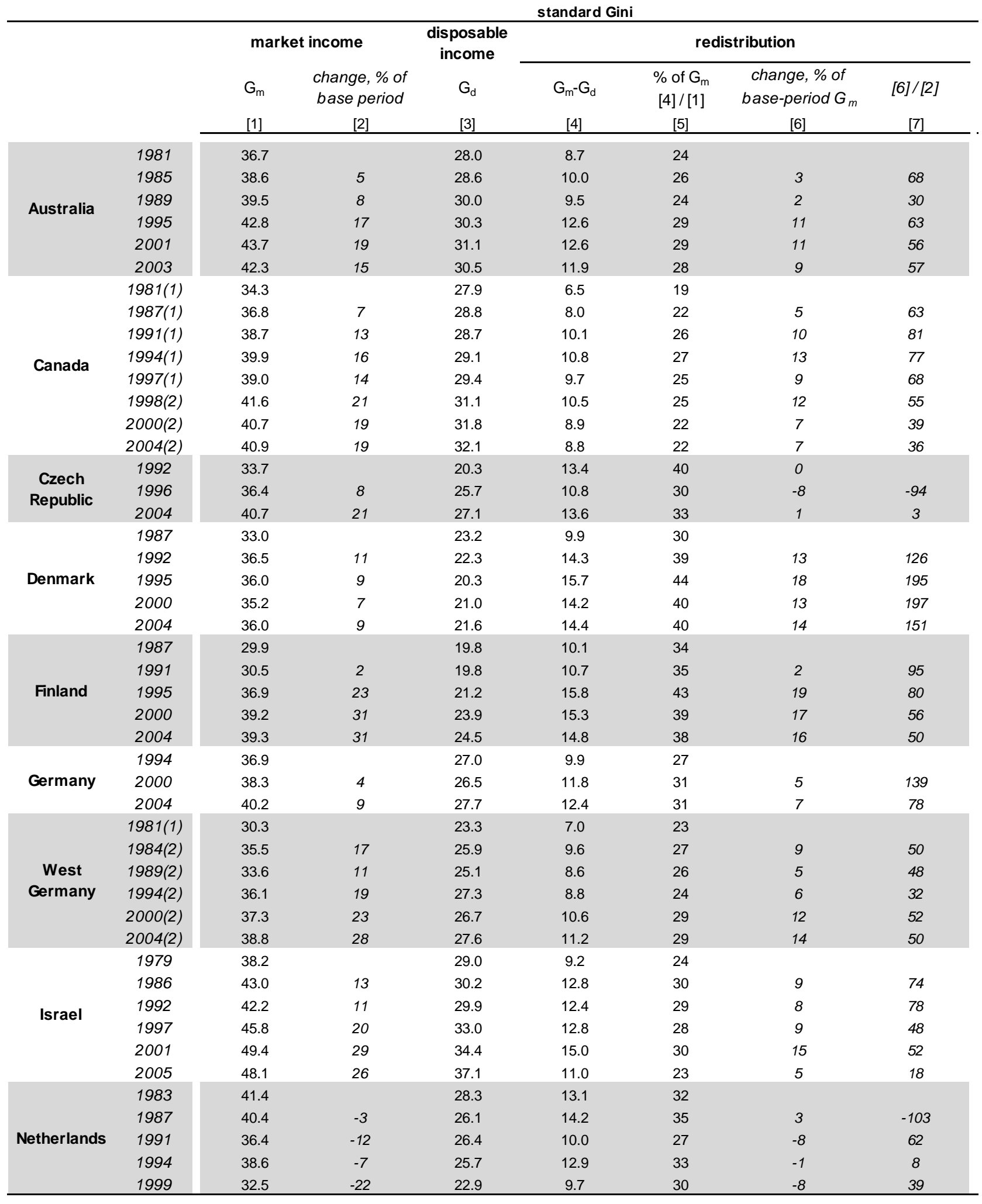


DELSA/ELSA/WD/SEM(2011)7

Table 5. (continued)

\begin{tabular}{|c|c|c|c|c|c|c|c|c|}
\hline & & \multicolumn{7}{|c|}{ standard Gini } \\
\hline & & \multicolumn{2}{|c|}{ market income } & \multirow{2}{*}{$\begin{array}{c}\text { disposable } \\
\text { income } \\
G_{d}\end{array}$} & \multicolumn{4}{|c|}{ redistribution } \\
\hline & & $\mathrm{G}_{\mathrm{m}}$ & $\begin{array}{c}\text { change, } \% \text { of } \\
\text { base period }\end{array}$ & & $\mathrm{G}_{\mathrm{m}}-\mathrm{G}_{\mathrm{d}}$ & $\begin{array}{c}\% \text { of } \mathrm{G}_{\mathrm{m}} \\
{[4] /[1]}\end{array}$ & $\begin{array}{c}\text { change, } \% \text { of } \\
\text { base-period } G_{m}\end{array}$ & {$[6] /[2]$} \\
\hline & & [1] & [2] & [3] & [4] & [5] & [6] & [7] \\
\hline \multirow{6}{*}{ Norway } & 1979 & 29.4 & & 21.1 & 8.3 & 28 & & \\
\hline & 1986 & 28.1 & -5 & 21.9 & 6.2 & 22 & -7 & 157 \\
\hline & 1991 & 32.0 & 9 & 22.5 & 9.5 & 30 & 4 & 46 \\
\hline & 1995 & 32.4 & 10 & 22.0 & 10.4 & 32 & 7 & 72 \\
\hline & 2000 & 34.7 & 18 & 24.6 & 10.1 & 29 & 6 & 34 \\
\hline & 2004 & 38.0 & 29 & 25.3 & 12.7 & 33 & 15 & 51 \\
\hline \multirow{2}{*}{ Poland } & 1999 & 42.0 & & 29.2 & 12.8 & 31 & & \\
\hline & 2004 & 46.9 & 12 & 33.1 & 13.8 & 29 & 2 & 19 \\
\hline \multirow{6}{*}{ Sweden } & 1981(1) & 30.4 & & 18.7 & 11.7 & 38 & & \\
\hline & $1987(1)$ & 31.3 & 3 & 19.1 & 12.2 & 39 & 2 & 54 \\
\hline & 1992(1) & 35.1 & 16 & 20.1 & 15.0 & 43 & 11 & 70 \\
\hline & 1995(1) & 37.4 & 23 & 19.6 & 17.8 & 48 & 20 & 87 \\
\hline & $2000(2)$ & 37.5 & 24 & 23.6 & 13.9 & 37 & 7 & 30 \\
\hline & $2005(2)$ & 36.9 & 21 & 22.2 & 14.7 & 40 & 10 & 46 \\
\hline \multirow{5}{*}{ Switzerland } & 1982(1) & 33.0 & & 30.2 & 2.8 & 8 & & \\
\hline & 1992(2) & 33.1 & 0 & 30.3 & 2.8 & 8 & 0 & -17 \\
\hline & $2000(3)$ & 31.7 & -4 & 27.6 & 4.1 & 13 & 4 & -101 \\
\hline & $2002(3)$ & 32.0 & -3 & 26.7 & 5.3 & 17 & 8 & -271 \\
\hline & $2004(3)$ & 31.3 & -5 & 25.8 & 5.5 & 18 & 8 & -167 \\
\hline \multirow{7}{*}{$\begin{array}{l}\text { United } \\
\text { Kingdom } \\
\text { (GB only) }\end{array}$} & 1979(1) & 33.5 & & 25.7 & 7.8 & 23 & & \\
\hline & 1986(1) & 42.9 & 28 & 30.2 & 12.7 & 30 & 15 & 52 \\
\hline & 1991(1) & 43.2 & 29 & 32.9 & 10.3 & 24 & 7 & 26 \\
\hline & 1994(2) & 46.3 & 38 & 34.0 & 12.3 & 27 & 13 & 35 \\
\hline & 1995(1) & 46.4 & 39 & 34.6 & 11.8 & 25 & 12 & 31 \\
\hline & 1999(2) & 46.0 & 37 & 34.8 & 11.3 & 24 & 10 & 28 \\
\hline & $2004(2)$ & 45.2 & 35 & 34.6 & 10.6 & 23 & 8 & 24 \\
\hline \multirow{7}{*}{ United States } & 1979 & 37.5 & & 30.1 & 7.4 & 20 & & \\
\hline & 1986 & 40.8 & 9 & 33.6 & 7.2 & 18 & -1 & -7 \\
\hline & 1991 & 41.0 & 9 & 33.6 & 7.3 & 18 & 0 & -3 \\
\hline & 1994 & 44.8 & 20 & 36.8 & 8.1 & 18 & 2 & 9 \\
\hline & 1997 & 44.9 & 20 & 37.4 & 7.5 & 17 & 0 & 1 \\
\hline & 2000 & 44.4 & 18 & 36.8 & 7.6 & 17 & 1 & 3 \\
\hline & 2004 & 45.4 & 21 & 37.3 & 8.1 & 18 & 2 & 9 \\
\hline
\end{tabular}

Notes: See Table 4. In case of a statistical break in the series, the superscripts next to the year correspond to different data sources.

The use of statistical data for Israel by the OECD is without prejudice to the status of the Golan Heights, East Jerusalem and Israeli settlements in the West Bank under the terms of international law.

Source: Authors' calculations based on the Luxembourg Income Study. 
Figure 7. Redistribution trends: Inequality before and after taxes and transfers

(a) Entire tax-benefit system: Gini coefficients before and after taxes and benefits

- - gross market income

$\rightarrow$ disposable income
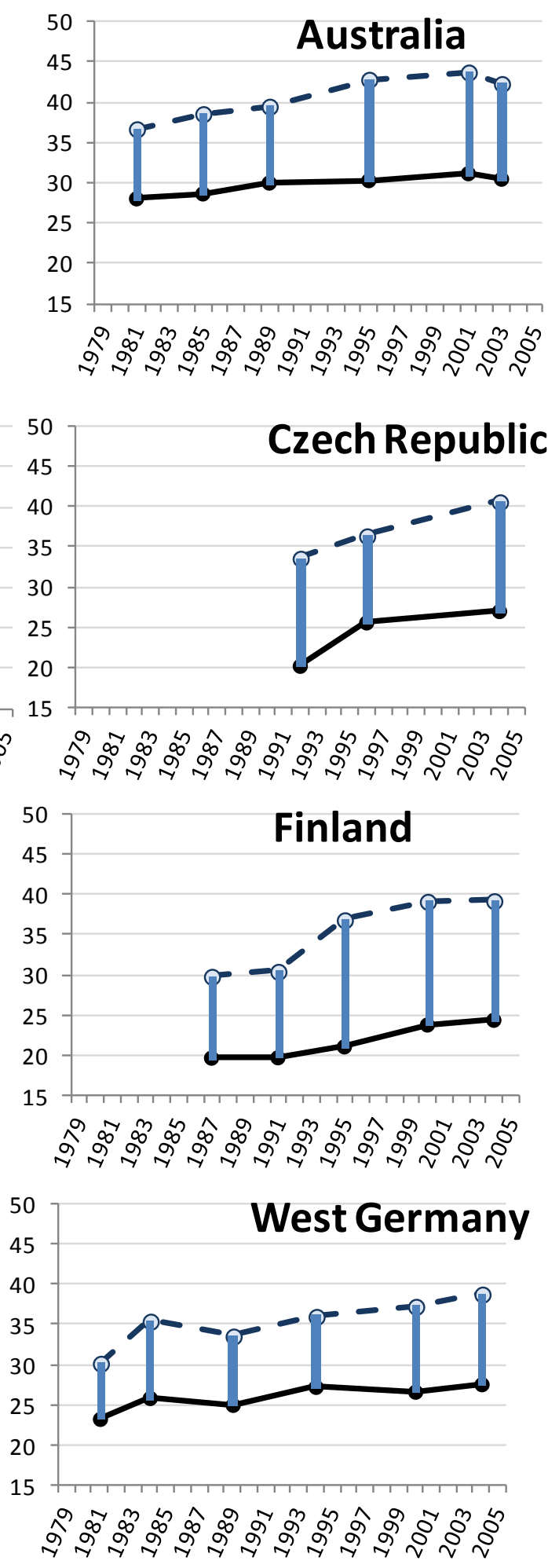
Figure 7 (continued)

(a) Entire tax-benefit system: Gini coefficients before and after taxes and benefits
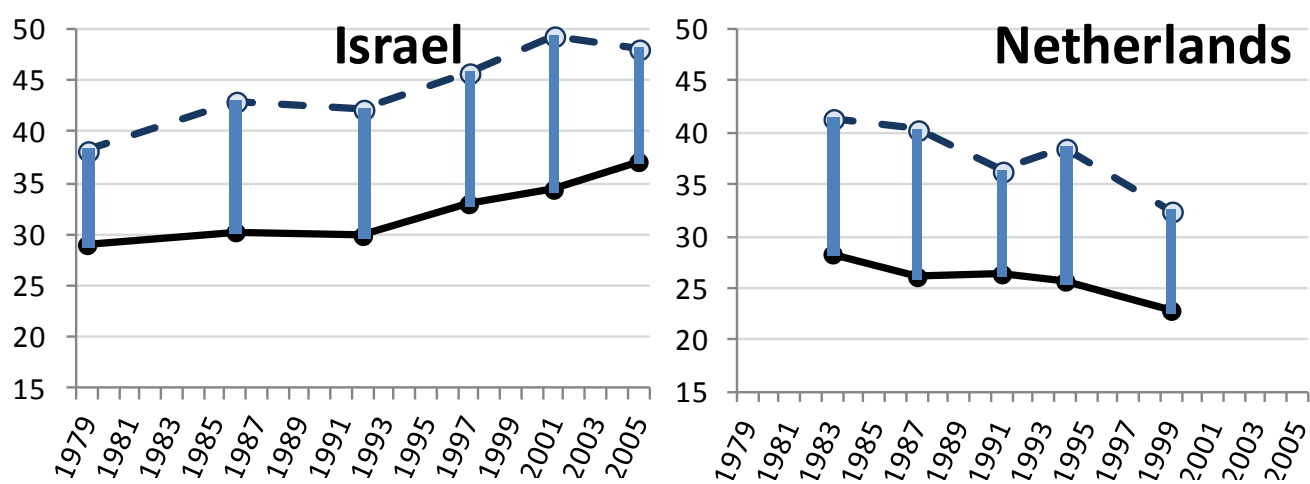

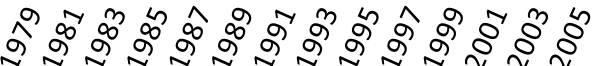
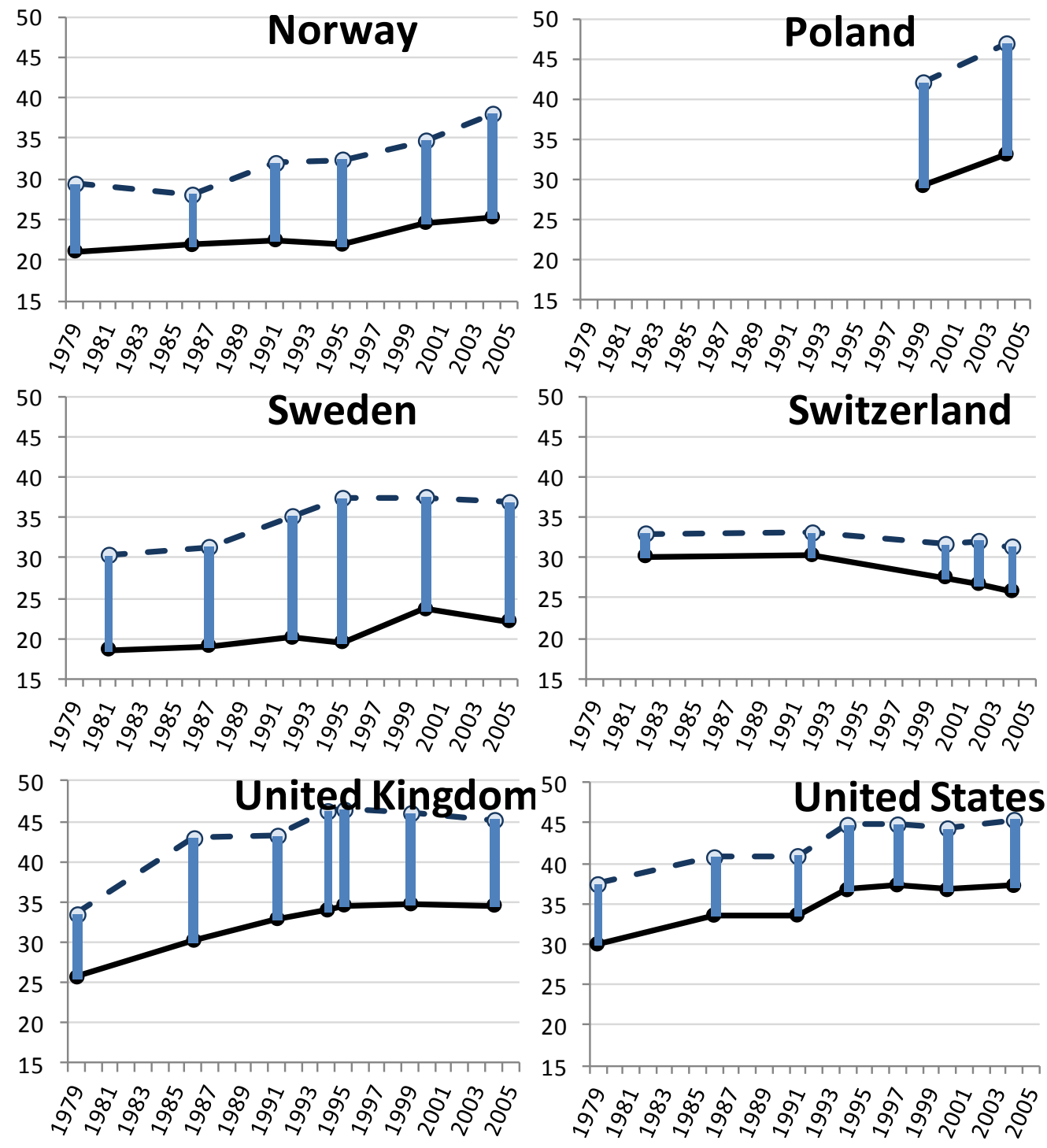

Notes: See Tables 4 and 5. Households headed by working-age individuals.

Source: Authors' calculations using data from the Luxembourg Income Study. 
Figure 7 (continued)

(b) Benefits only: Gini coefficients before and after benefits (countries without data on taxes)

$-\infty$ net market income

$\rightarrow$ disposable income
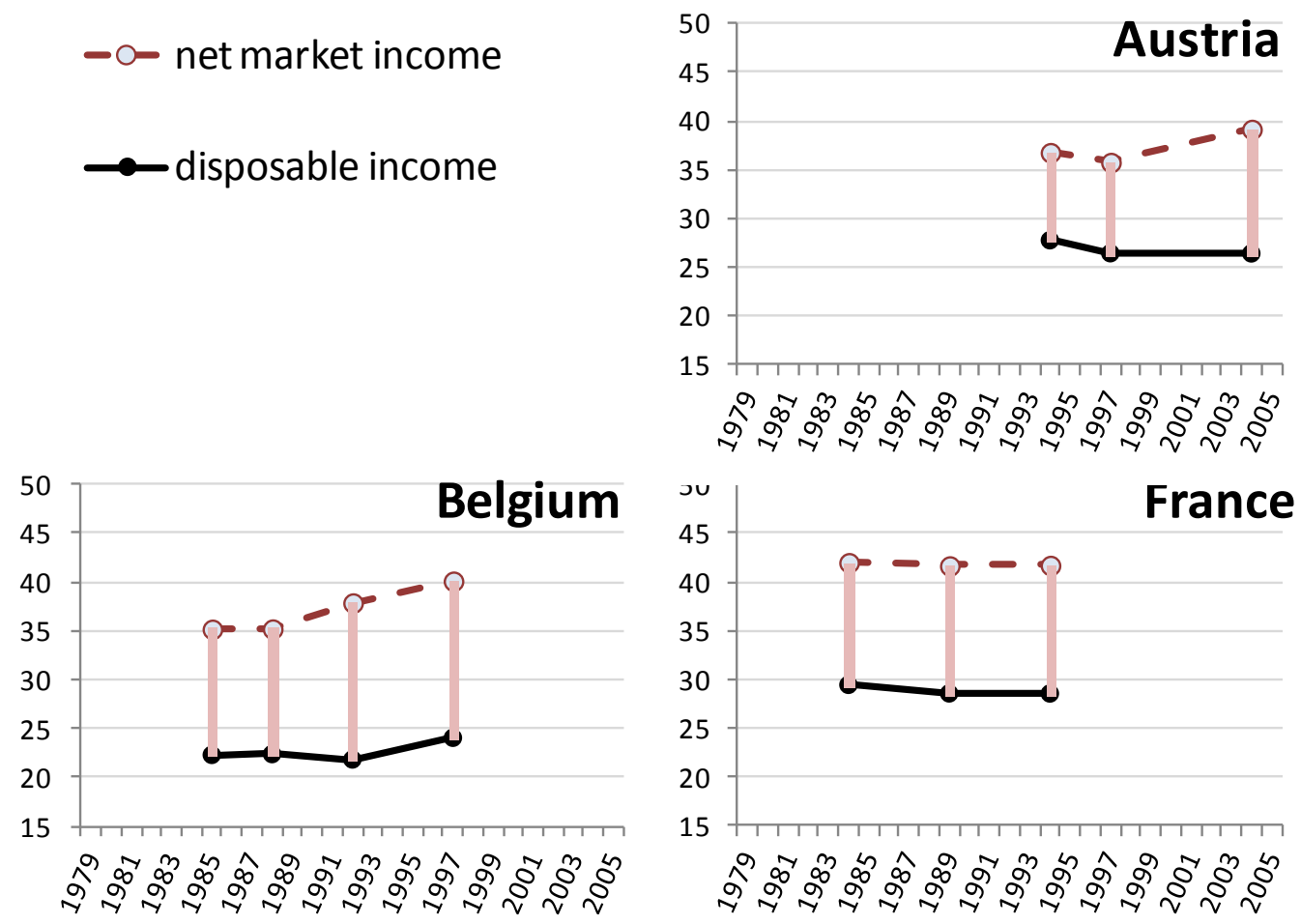

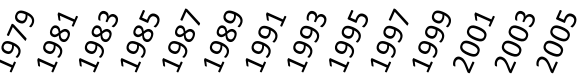
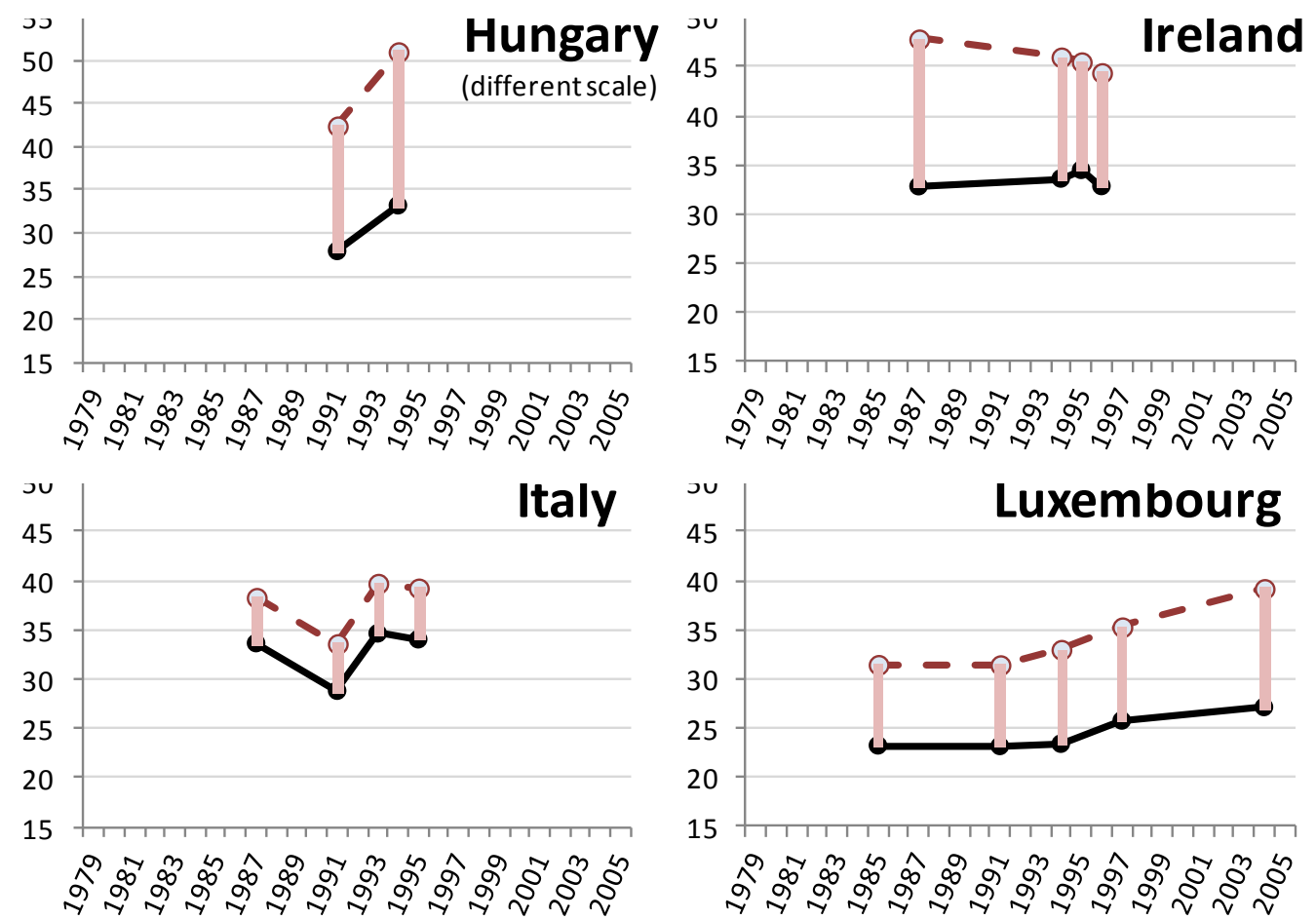
Figure 7 (continued)

(b) Benefits only: Gini coefficients before and after benefits (countries without data on taxes)

\section{- O- net market income}

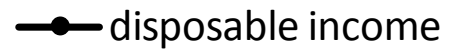

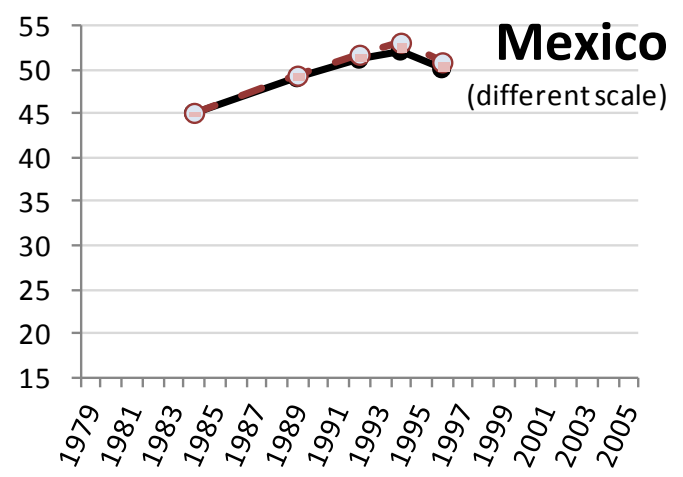
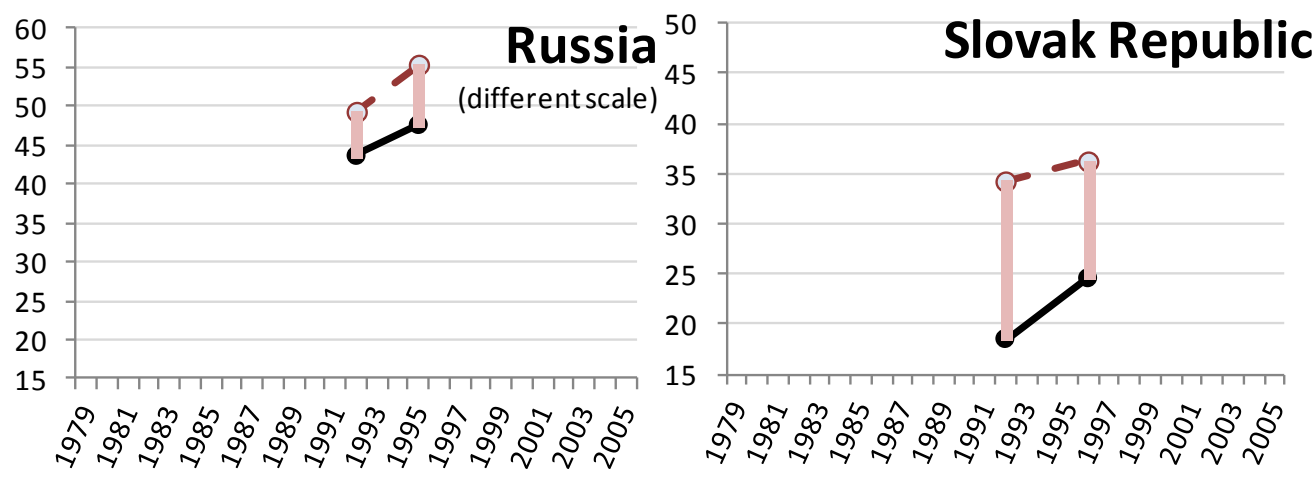

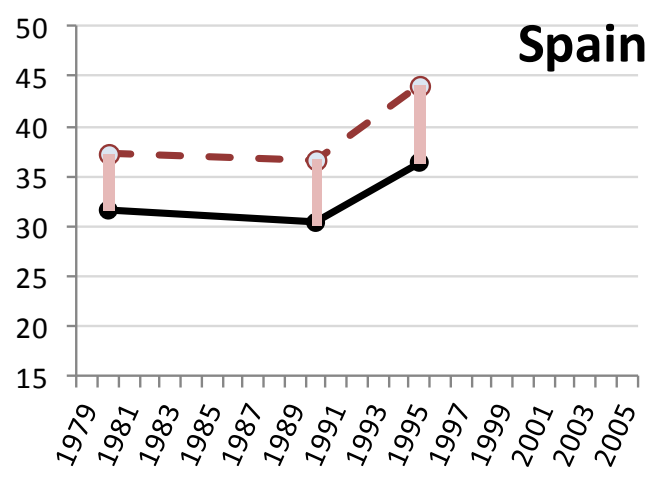

Notes: See notes to Tables 4 and 5. Households headed by working-age individuals. Net market income is market income plus private transfers minus income taxes and social contributions paid by households.

Source: Authors' calculations using data from the Luxembourg Income Study.

39. As noted in the introduction, one would expect a positive link between market-income inequality and redistribution even in the absence of any conscious policy effort to counter inequality trends (Musgrave and Thin, 1948; Dardoni and Lambert, 2002): because of the progressivity built into tax-benefit systems, a more dispersed market-income distribution (e.g., due to higher unemployment), automatically strengthens the equalising effect of an unchanged policy configuration. For instance, it is interesting to note the very strong increase in total redistribution during the first Thatcher government in the United Kingdom (Figure 7), which cannot be explained by policy reforms.

40. Figure 8 plots redistribution coefficients against market-income inequality and illustrates the mostly positive correlation between the two, both within countries (dashed regression lines) and across all 
observations (solid line). The scatter plot suggests, however, that this link is stronger in some countries than in others. All else equal, a more progressive tax-benefit system will tend to compensate a greater part of any increase in market-income inequality. At the bottom of the distribution, the generosity of out-ofwork benefits is a decisive factor, while progressively increasing income tax rates can to some extent counter growing income gaps at the top. In Figure 8, the flat trend line for the United States is, for instance, consistent with relatively weak automatic inequality-dampening properties of the US tax-benefit system. However, in addition to the automatic changes in redistribution, active policy changes do of course matter and shape the response of redistribution systems to changing market-income inequality.

41. Indeed, the sometimes sizable departures from the average correlation suggest that policy interventions have played an important role, in addition to the automatic "break" that prevailing progressive tax-benefit systems have put on inequality trends. The data in Table 5 illustrate episodes in a number of countries where, as noted above, reductions in the redistributive capacity of taxes and benefits have sometimes occurred in parallel with increasing market-income inequality (Australia 1985-89, Czech Republic 1992-96, Finland 1995-2004, Israel 1997-2005, United Kingdom 1986-95, and United States 1979-86 and 1994-97). In these cases, policy reforms have accelerated the trend towards greater income inequality. In a few cases, redistribution has declined by a sufficient margin to push up inequality after taxes and benefits despite a fall in the market-income Gini (Denmark, 1995-2000; Israel, 2001-05; Norway, 1979-86; United Kingdom, 1994-2004).

Figure 8. Redistribution tends to be higher when incomes are more unequal

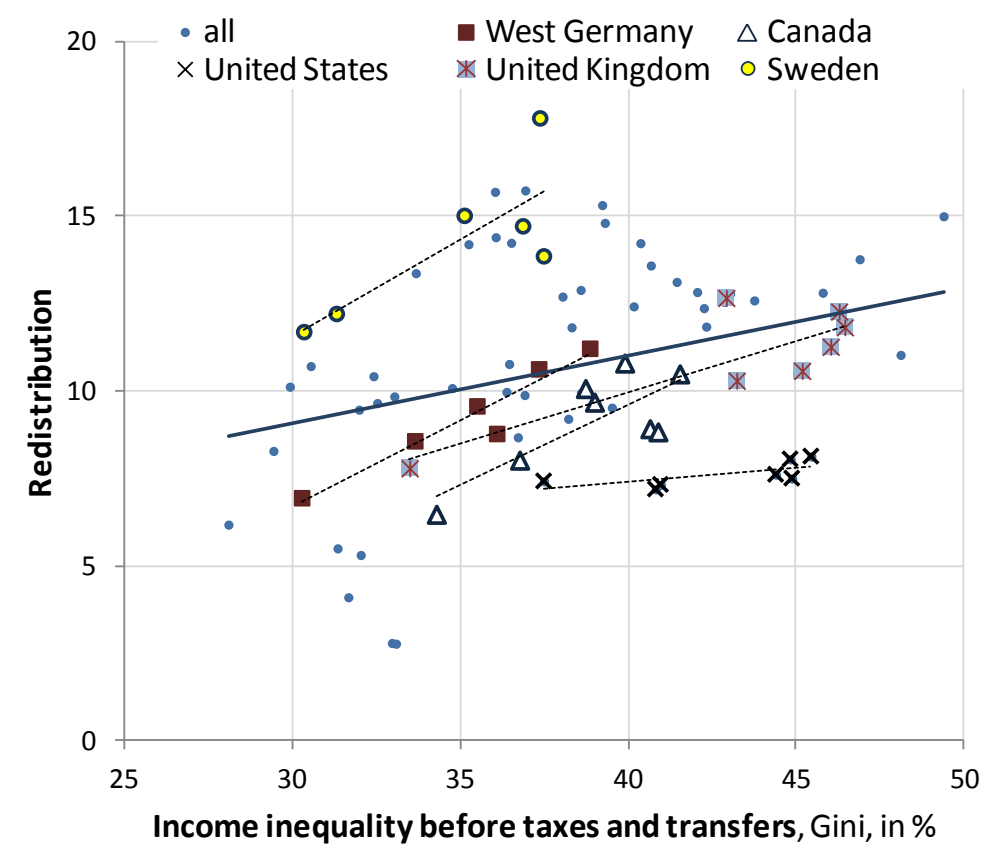

Notes: See notes to Tables 4 and 5. Redistribution is the absolute difference between the Gini coefficients before and after taxes and transfers. All measures are based on equivalised household income using the square-root equivalence scale.

Source: Authors' calculations using data from the Luxembourg Income Study.

\subsubsection{Did changes in redistribution affect mainly families with higher or lower incomes?}

42. Over longer time periods, trends in inequality and redistribution result from a complex pattern of income and policy changes affecting all income groups. The mechanisms underlying these changes, as well as possible policy responses, differ substantially between groups, however. At the bottom of the 
distribution, changes in inequality are driven to a large extent by joblessness and the labour-market situation of low-skilled workers, as well as the availability and generosity of social benefits. At the top, capital incomes and tax policy are more important. How different income groups were affected by observed inequality trends is therefore a question of considerable policy relevance.

43. The income trends presented in Figure 1 have suggested that losses at the bottom can be a very sizable contributor to growing income gaps between families. In order to gauge how redistribution systems have responded to these changes, it is useful to calculate alternative Gini and redistribution measures that put more weight on the situation of low-income groups (this can be interpreted as choosing a social welfare function that attaches greater importance to the situation of low-income households, see Duclos, 2000). Such measures are reported in Table 6, alongside the standard Gini measures discussed above, and a third set of measures that place more weight on high-income groups. ${ }^{20}$

44. Results show that redistribution systems in most countries were somewhat more successful at offsetting growing income gaps at the bottom than at the top. For instance, in Germany, the tax-benefit system compensated almost $82 \%$ of rising income inequalities between 1994 and 2004 when more weight is put on low-income groups ("compensation ratio" in column 6), compared with $78 \%$ when using the standard Gini (and only 73\% when income gaps at the top receive more weight). One notable implication of this result is that benefits (which are more important for low-income groups) tended to be more responsive to growing inequalities than were taxes (which account for a greater part of incomes in the middle and at the top of the distribution).

45. Unlike in most other countries, tax-benefit systems in the Czech Republic, Israel, Poland and the United States were relatively less effective at countering growing disparities in the lower part of the income distribution. In these countries, redistribution offset only a relatively small part of the sizable increase in the market-income Gini since 1979, and an even smaller part when greater weight is attached to low-income households (13\% in Israel and Poland, 6\% in the United States, diminished redistribution in the Czech Republic). A possible explanation for this result is that benefits provide a lesser degree of income protection than in other countries, and that tax policy is therefore a relatively more important driver of inequality outcomes.

20. Inequality measures that put greater weight on high-income groups need to be interpreted with care as a higher weight exacerbates measurement issues arising from the limited quality of higher-income data drawn from survey sources. These indicators are also more sensitive to the commonly used, but arbitrary, approach of censoring high incomes at 10 times the median (see note to Table 4). 
Table 6. Redistribution systems generally compensated a greater part of growing inequalities at the bottom than at the top ${ }^{1}$

\begin{tabular}{|c|c|c|c|c|c|c|c|c|c|c|}
\hline & & \multicolumn{3}{|c|}{ standard Gini } & \multicolumn{3}{|c|}{ more weight on low incomes $(S-G i n i, v=3)^{3}$} & \multicolumn{3}{|c|}{ more weight on high incomes (S-Gini, $v=1.5)$} \\
\hline & & $\begin{array}{c}\text { change in } \\
\text { market-income } \\
\text { inequality }^{2}\end{array}$ & $\begin{array}{l}\text { change in } \\
\text { redistribution }{ }^{2}\end{array}$ & $\begin{array}{c}\text { compensatio } \\
\text { n ratio } \\
{[2] /[1]}\end{array}$ & $\begin{array}{c}\text { change in } \\
\text { market-income } \\
\text { inequality }^{2}\end{array}$ & $\begin{array}{l}\text { change in } \\
\text { redistribution }\end{array}$ & $\begin{array}{c}\text { compensatio } \\
\text { n ratio } \\
{[2] /[1]}\end{array}$ & $\begin{array}{l}\text { change in } \\
\text { market-income } \\
\text { inequality }^{2}\end{array}$ & $\begin{array}{c}\text { change in } \\
\text { redistribution }\end{array}$ & $\begin{array}{c}\text { compensatio } \\
n \text { ratio } \\
{[2] /[1]}\end{array}$ \\
\hline & & [1] & [2] & [3] & [4] & [5] & [6] & [7] & [8] & [9] \\
\hline \multirow{6}{*}{ Australia } & 1981 & . & . & . & . & . & . & . & . & . \\
\hline & 1985 & 5 & 3 & 68 & 4 & 3 & 73 & 7 & 5 & 65 \\
\hline & 1989 & 8 & 2 & 30 & 6 & 2 & 29 & 10 & 3 & 30 \\
\hline & 1995 & 17 & 11 & 63 & 15 & 10 & 71 & 19 & 11 & 57 \\
\hline & 2001 & 19 & 11 & 56 & 16 & 10 & 62 & 22 & 11 & 50 \\
\hline & 2003 & 15 & 9 & 57 & 13 & 8 & 63 & 18 & 9 & 51 \\
\hline \multirow{8}{*}{ Canada } & 1981(1) & . & . & . & . & . & . & . & . & . \\
\hline & 1987(1) & 7 & 5 & 63 & 6 & 4 & 68 & 8 & 5 & 59 \\
\hline & 1991(1) & 13 & 10 & 81 & 11 & 10 & 86 & 15 & 12 & 77 \\
\hline & 1994(1) & 16 & 13 & 77 & 15 & 12 & 80 & 18 & 13 & 75 \\
\hline & 1997(1) & 14 & 9 & 68 & 13 & 9 & 72 & 15 & 10 & 66 \\
\hline & 1998(2) & 21 & 12 & 55 & 18 & 10 & 59 & 25 & 13 & 52 \\
\hline & $2000(2)$ & 19 & 7 & 39 & 14 & 6 & 42 & 24 & 9 & 36 \\
\hline & $2004(2)$ & 19 & 7 & 36 & 15 & 6 & 38 & 24 & 8 & 34 \\
\hline \multirow{3}{*}{$\begin{array}{l}\text { Czech } \\
\text { Republic }\end{array}$} & 1992 & . & & . & . & . & . & . & . & . \\
\hline & 1996 & 8 & -8 & -94 & 6 & -10 & -166 & 10 & -6 & -56 \\
\hline & 2004 & 21 & 1 & 3 & 17 & -2 & -11 & 24 & 3 & 13 \\
\hline \multirow{5}{*}{ Denmark } & 1987 & . & . & . & . & . & . & . & . & . \\
\hline & 1992 & 11 & 13 & 126 & 10 & 12 & 116 & 10 & 14 & 133 \\
\hline & 1995 & 9 & 18 & 195 & 8 & 16 & 196 & 9 & 19 & 201 \\
\hline & 2000 & 7 & 13 & 197 & 6 & 12 & 210 & 8 & 15 & 190 \\
\hline & 2004 & 9 & 14 & 151 & 8 & 12 & 152 & 10 & 15 & 152 \\
\hline \multirow{5}{*}{ Finland } & 1987 & . & . & . & . & . & . & . & . & . \\
\hline & 1991 & 2 & 2 & 95 & 2 & 2 & 100 & 2 & 2 & 92 \\
\hline & 1995 & 23 & 19 & 80 & 22 & 19 & 88 & 24 & 18 & 73 \\
\hline & 2000 & 31 & 17 & 56 & 29 & 19 & 63 & 33 & 16 & 49 \\
\hline & 2004 & 31 & 16 & 50 & 29 & 16 & 56 & 34 & 15 & 45 \\
\hline \multirow{3}{*}{ Germany } & 1994 & . & . & . & . & . & . & . & . & . \\
\hline & 2000 & 4 & 5 & 139 & 3 & 5 & 152 & 4 & 5 & 127 \\
\hline & 2004 & 9 & 7 & 78 & 8 & 6 & 82 & 9 & 7 & 73 \\
\hline \multirow{6}{*}{$\begin{array}{l}\text { West } \\
\text { Germany }\end{array}$} & 1981(1) & . & . & . & . & . & . & . & . & . \\
\hline & $1984(2)$ & 17 & 9 & 50 & 16 & 8 & 50 & 19 & 10 & 50 \\
\hline & 1989(2) & 11 & 5 & 48 & 9 & 5 & 48 & 13 & 7 & 49 \\
\hline & 1994(2) & 19 & 6 & 32 & 18 & 6 & 31 & 20 & 6 & 32 \\
\hline & $2000(2)$ & 23 & 12 & 52 & 21 & 11 & 53 & 25 & 13 & 51 \\
\hline & $2004(2)$ & 28 & 14 & 50 & 26 & 13 & 51 & 30 & 14 & 47 \\
\hline \multirow{6}{*}{ Israel } & 1979 & . & . & . & . & . & . & . & . & . \\
\hline & 1986 & 13 & 9 & 74 & 11 & 8 & 72 & 15 & 11 & 77 \\
\hline & 1992 & 11 & 8 & 78 & 10 & 8 & 78 & 11 & 9 & 81 \\
\hline & 1997 & 20 & 9 & 48 & 17 & 8 & 45 & 22 & 11 & 50 \\
\hline & 2001 & 29 & 15 & 52 & 26 & 13 & 51 & 32 & 17 & 52 \\
\hline & 2005 & 26 & 5 & 18 & 23 & 3 & 13 & 28 & 6 & 22 \\
\hline \multirow{5}{*}{ Netherlands } & 1983 & . & . & . & . & . & . & . & . & . \\
\hline & 1987 & -3 & 3 & -103 & -2 & 3 & -127 & -3 & 3 & -95 \\
\hline & 1991 & -12 & -8 & 62 & -11 & -6 & 56 & -13 & -9 & 69 \\
\hline & 1994 & -7 & -1 & 8 & -5 & -1 & 13 & -8 & 0 & 3 \\
\hline & 1999 & -22 & -8 & 39 & -20 & -8 & 39 & -22 & -9 & 39 \\
\hline
\end{tabular}


Table 6. (continued)

\begin{tabular}{|c|c|c|c|c|c|c|c|c|c|c|}
\hline & & \multicolumn{3}{|c|}{ standard Gini } & \multicolumn{3}{|c|}{ more weight on low incomes $(S-G i n i, v=3)^{3}$} & \multicolumn{3}{|c|}{ more weight on high incomes (S-Gini, $v=1.5)^{3}$} \\
\hline & & $\begin{array}{c}\text { change in } \\
\text { market-income } \\
\text { inequality }^{2}\end{array}$ & $\begin{array}{c}\text { change in } \\
\text { redistribution }\end{array}$ & $\begin{array}{c}\text { compensatio } \\
n \text { ratio } \\
{[2] /[1]}\end{array}$ & $\begin{array}{c}\text { change in } \\
\text { market-income } \\
\text { inequality }^{2}\end{array}$ & $\begin{array}{c}\text { change in } \\
\text { redistribution }\end{array}$ & $\begin{array}{c}\text { compensatio } \\
\text { n ratio } \\
{[2] /[1]}\end{array}$ & $\begin{array}{c}\text { change in } \\
\text { market-income } \\
\text { inequality }^{2}\end{array}$ & $\begin{array}{l}\text { change in } \\
\text { redistribution }\end{array}$ & $\begin{array}{c}\text { compensatio } \\
\text { n ratio } \\
{[2] /[1]}\end{array}$ \\
\hline & & [1] & [2] & [3] & [4] & [5] & [6] & [7] & [8] & [9] \\
\hline \multirow{6}{*}{ Norway } & 1979 & . & . & . & . & . & . & . & . & . \\
\hline & 1986 & -5 & -7 & 157 & -4 & -6 & 151 & -5 & -8 & 155 \\
\hline & 1991 & 9 & 4 & 46 & 8 & 4 & 52 & 10 & 4 & 39 \\
\hline & 1995 & 10 & 7 & 72 & 9 & 8 & 83 & 12 & 7 & 59 \\
\hline & 2000 & 18 & 6 & 34 & 14 & 6 & 39 & 23 & 6 & 28 \\
\hline & 2004 & 29 & 15 & 51 & 25 & 14 & 55 & 33 & 15 & 45 \\
\hline \multirow{2}{*}{ Poland } & 1999 & . & . & . & . & . & . & . & . & . \\
\hline & 2004 & 12 & 2 & 19 & 9 & 1 & 13 & 13 & 3 & 22 \\
\hline \multirow{6}{*}{ Sweden } & 1981(1) & . & . & . & . & . & . & . & . & . \\
\hline & 1987(1) & 3 & 2 & 54 & 2 & 1 & 55 & 4 & 2 & 49 \\
\hline & 1992(1) & 16 & 11 & 70 & 15 & 12 & 81 & 16 & 10 & 59 \\
\hline & 1995(1) & 23 & 20 & 87 & 21 & 21 & 98 & 25 & 19 & 78 \\
\hline & $2000(2)$ & 24 & 7 & 30 & 19 & 7 & 37 & 29 & 8 & 27 \\
\hline & 2005(2) & 21 & 10 & 46 & 18 & 10 & 53 & 25 & 11 & 42 \\
\hline \multirow{5}{*}{ Switzerland } & 1982(1) & . & . & . & . & . & . & . & . & . \\
\hline & 1992(2) & 0 & 0 & -17 & 4 & -1 & -36 & -3 & 1 & -28 \\
\hline & $2000(3)$ & -4 & 4 & -101 & 0 & 5 & -3583 & -8 & 3 & -40 \\
\hline & 2002(3) & -3 & 8 & -271 & 2 & 8 & 524 & -7 & 7 & -95 \\
\hline & 2004(3) & -5 & 8 & -167 & 1 & 10 & 759 & -11 & 7 & -59 \\
\hline \multirow{7}{*}{$\begin{array}{l}\text { United } \\
\text { Kingdom } \\
\text { (GB only) }\end{array}$} & 1979(1) & . & . & . & . & . & . & . & . & . \\
\hline & 1986(1) & 28 & 15 & 52 & 26 & 14 & 53 & 29 & 15 & 50 \\
\hline & 1991(1) & 29 & 7 & 26 & 26 & 7 & 29 & 32 & 7 & 23 \\
\hline & 1994(2) & 38 & 13 & 35 & 34 & 14 & 41 & 43 & 13 & 30 \\
\hline & 1995(1) & 39 & 12 & 31 & 35 & 12 & 34 & 43 & 12 & 28 \\
\hline & 1999(2) & 37 & 10 & 28 & 32 & 10 & 31 & 43 & 11 & 26 \\
\hline & $2004(2)$ & 35 & 8 & 24 & 30 & 9 & 29 & 40 & 8 & 19 \\
\hline \multirow{7}{*}{$\begin{array}{l}\text { United } \\
\text { States }\end{array}$} & 1979 & . & . & . & . & . & . & . & . & . \\
\hline & 1986 & 9 & -1 & -7 & 7 & -1 & -8 & 10 & -1 & -6 \\
\hline & 1991 & 9 & 0 & -3 & 8 & 0 & 0 & 10 & -1 & -6 \\
\hline & 1994 & 20 & 2 & 9 & 16 & 1 & 7 & 23 & 2 & 10 \\
\hline & 1997 & 20 & 0 & 1 & 14 & 0 & 0 & 26 & 0 & 2 \\
\hline & 2000 & 18 & 1 & 3 & 12 & 0 & -3 & 25 & 1 & 4 \\
\hline & 2004 & 21 & 2 & 9 & 15 & 1 & 6 & 28 & 2 & 9 \\
\hline
\end{tabular}

1. See notes to Tables 4 and 5 .

2. Changes in percent of market-income inequality in base period.

3. S-Gini indicators are a generalised version of the Gini which allows for an "inequality aversion" parameter $v$ (Donaldson and Weymark, 1980; Yitzhaki, 1983). A parameter $v=2$ corresponds to the standard Gini.

Source: Authors' calculations based on the Luxembourg Income Study (LIS).

\subsubsection{A closer look at the role of different parts of the redistribution system}

46. Before turning to a descriptive account of policy changes, a more detailed look at tax payments and benefit receipt can shed some light on the overall contributions of different policy areas to observed redistribution trends. Without detailed policy information, a conclusive analysis of the extent to which policy reforms reinforced or counteracted the automatic inequality mitigation built into progressive taxbenefit systems is not possible. The household income data do, however, allow investigating how the redistributive effect of different parts of the tax-benefit system has changed (whether as a result of policy changes or because of other factors, such as higher unemployment). To do this, Figure 9 compares the equalising effects at different stages of the redistribution process, with changes over time shown separately for benefits, social contributions and income taxes. "Benefits", as defined here, include important tax credits that are akin to cash transfers (such as employment-conditional "in-work" tax credits in the United 
States and the United Kingdom). ${ }^{21}$ To gauge what drove changes in redistribution, Figure 9 also shows changes in both the size and the progressivity of each of the three redistribution instruments. Box 2 explains how these indicators were calculated.

\section{Box 2. Measuring redistribution achieved by individual parts of the tax-transfer system}

In principle, the redistributive effect of individual parts of the tax-benefit system can be measured in the same way as for all taxes and transfers taken together. Following the approach taken above, this implies comparing Gini coefficients of income before and after adding the benefit or subtracting the tax in question. ${ }^{1}$ For instance, to calculate the redistributive effect of taxes, one could calculate a Gini value of market incomes minus taxes (this may be called net-of-tax Gini), and subtract it from the Gini value of market incomes. Likewise, the equalising effect of benefits could be determined by comparing Gini values for net-of-tax incomes on one hand, and net-of-tax incomes plus benefits (= disposable income) on the other.

\section{Accounting for the integration of individual measures into the overall tax-benefit system}

Applying this approach in practice is not straightforward, however. The reason is that benefits and taxes interact with each other in different ways across countries. As a result, the sequence used for the Gini comparisons of the different tax/benefit elements matters, and can make a significant difference for the results (the sequence is obviously not an issue when calculating redistribution for the tax-benefit system as a whole). For instance, when benefits are taxable, many benefit recipients with zero market incomes will have positive tax burdens. As a result, determining the redistributive effect of taxes based on a comparison of market incomes and market income minus taxes would provide a distorted picture, as positive taxes paid by those with zero incomes can make the tax appear regressive. Likewise, determining the redistributive power of benefits based on comparing market incomes and market incomes plus benefits can provide a misleading picture if benefit amounts depend largely on after-tax incomes (as is the case when benefits are comprehensively means-tested).

Because the appropriate sequence will depend on the structure of the specific tax-benefit system, choosing an arbitrary sequence, as is sometimes done, is especially problematic in a cross-country context. A technical solution that is sometimes proposed (and is based on the so-called Shapley value procedure; see Shorrocks, 1999) essentially averages over all possible sequences. This, however, is also not satisfactory as the average will still be affected by sequences that are not appropriate given the tax-benefit structure in a given country.

To address these problems, the measurement approach that is chosen here reflects, as far as possible, the actual legal sequence that is implicit in each country's tax-benefit system:

1 In countries where taxes payable on benefits are quantitatively important (and tax burdens therefore depend on benefits), the redistributive effect of taxes is assessed against market income plus benefits (i.e., by comparing market incomes plus benefits minus taxes to market income plus benefits). Likewise, the redistributive power of benefits is determined by comparing Ginis of market incomes and market incomes plus benefits. This approach is used for Canada, Denmark, Finland, Netherlands, Norway, Poland, Sweden, Switzerland, United Kingdom.

2 In countries where taxes payable on benefits are quantitatively not very important or where, because of means testing, taxes payable on market incomes affect benefit entitlements, the redistributive effect of benefits is assessed against net-of-tax incomes (market income minus taxes), i.e., by comparing market incomes plus benefits minus taxes with net-of-tax income. The redistributive power of taxes is determined by comparing Ginis of market incomes and net-of-tax incomes. This approach is used for Australia, Czech Republic, Germany, Israel, United States.

3 Social security contributions are often deductible from the income-tax base and, hence, affect income-tax burdens. Income taxes, on the other hand, usually do not affect social-security-contribution liabilities. In the results reported here, the redistributive effect of social security contributions is therefore assessed against before-tax incomes, while the redistribution achieved by income taxes is determined relative to before-tax incomes minus social contributions.

21. Following the definitions spelled out in Box 1, "social contribution" include only that part that is formally paid by households while employer contributions and payroll taxes are not considered. Importantly, and as noted in Box 1, taxes other than income taxes (wealth, property and indirect taxes) are also not considered. 
Arguably, the chosen measurement approach is particularly suitable for evaluating redistribution changes for each of the three types of government programme. Because the ranking of households differs between the baselines used for calculating redistributive effects of the different tax/benefit components, it is, however, not a formal decomposition approach (i.e., the redistributive effect of benefits, social contributions and taxes does not precisely sum up to the overall redistributive effect shown in Figure 7). For similar reasons, indicator levels are also not strictly comparable across the three categories. A potential problem of the chosen approach arises if the legal sequence in a given country changes over time (for instance, some benefits that were not taxable in the baseline year become taxable later on). Complete reversals of the sequence are rare, however, and are not documented for any of the timeperiods and countries considered here (also, the problem is, in any case, also encountered by the alternative approach that uses an arbitrary sequence).

\section{Progressivity and size of a tax or benefit}

Progressivity is measured using the commonly used Kakwani indicator (Kakwani, 1977), which is the concentration coefficient of the tax (or benefit) minus the Gini coefficient of pre-tax (or pre-benefit) income and quantifies the departure of the distribution of a tax or benefit payment from proportionality. A tax or benefit that is distributed in proportion to pre-tax (or pre-benefit) income has zero progressivity (the concentration coefficient equals the Gini coefficient), and no redistributive effect whatever the size of the tax or benefit. The Kakwani indicator ranges from plus 1 (maximum progressivity) to minus 2 (maximum regressivity). Note that, in the case of benefits, there is an important difference between a technically correct use of these terms, and frequently used language that refer to inequality-reducing transfers as "progressive". In a technical sense, benefits are normally regressive as social transfers tend to decline at higher income levels. For a given size of the redistribution instrument, the more regressive a benefit, and the more progressive a tax, the bigger is its equalising effect.

The size of the tax-benefit instrument is measured as the effective tax rate (or benefit rate): all taxes paid (or benefits received) by the household, divided by the household's pre-tax (or pre-benefit) income, averaged over all households. For benefits, the size indicator is negative (which, in combination with a negative progressivity indicator, results in positive redistribution).

1. All redistribution and progressivity measures reported here for individual parts of the tax-benefit system are based on the standard Gini. In principle, they can also be based on alternative versions of the Gini that put more weight on lower or higher incomes.

47. In most of the 15 countries for which LIS data on tax and benefit payments span a longer time period, benefits have become more important for reducing inequalities (top panel of Figure 9a). There are only three countries, where benefits to "non-elderly" households were significantly less redistributive in the mid-2000s than in the mid-1980s (Israel, the United Kingdom, as well as the Netherlands - one of the two countries where market-income inequality has fallen over the period). But since the mid-1990s, benefits became less effective at reducing inequality in half of the countries. Where the redistributive effect of benefits increased strongly, the trend was largely driven by growing average benefit amounts (Finland, Germany, Norway, Switzerland). This can be seen from the middle panel of Figure 9a, which expresses the size of benefits in terms of a "tax rate" measure (and therefore shows negative values for benefits, see Box 2). While this measure is very different from the spending-to-GDP ratios discussed earlier, the four countries showing increasing average benefit rates in Figure 9 are also among those with growing aggregate spending relative to GDP.

48. The degree of benefit progressivity has changed less in most countries (bottom panel, see Box 2 for details on this specific indicator). Where benefits did become more (Australia, Czech Republic, Finland, Norway) or less (Germany, Netherland, Switzerland, United States) targeted towards the poor since the mid-1980s, this did not change the overall trend in redistribution that would result from trends in average benefit rates alone. In the United Kingdom, a large increase in progressivity prevented benefits from becoming less redistributive between the mid-80s and the mid-90s despite much-reduced average benefit levels. Over two decades, benefits in the United Kingdom did, however, become less redistributive despite being now more tightly targeted towards the poor. The opposite holds for Germany. The relatively small change in benefit progressivity, and its limited impact on the redistribution properties of cash transfers over a 20-year period, highlight the importance of overall spending levels for inequality outcomes 
(in a sense, societies get the inequality reduction they are prepared to pay for). It also indicates the potential difficulties of maintaining redistribution in a context of declining budgets for social spending.

49. By gauging the orders of magnitude in Figures $9 \mathrm{a}, \mathrm{b}$ and $\mathrm{c}$, it is clear that benefits have a much stronger impact on inequality than social contributions or taxes, despite the bigger size indicator for direct taxes and, hence, their bigger average impact on household incomes. ${ }^{22}$ Changes on the benefit side can therefore also be expected to be a more significant driver of the extent of overall redistribution. Indeed, in terms of the reduction of the Gini coefficient, the maximum change in redistribution is less than 2 points for taxes and contributions (in Israel), compared with more than 5 points for benefits (in Finland, Norway, Sweden and Switzerland).

50. Social contributions are sizable and have become more so in just over half the countries shown in Figure 9b (middle panel). Due to the frequent use of upper contribution limits, and the flat payment schedule below those limits, they are regressive on average and, hence, raise cross-sectional income inequality. With the exception of Poland, the progressivity measure is nevertheless close to zero, indicating that contributions are a relatively constant proportion of market income over most income ranges. As a result, even sizable changes in the overall contribution burden change the redistributive effect by a relatively small amount (top panel). Because rate structures have essentially been the same 20 years earlier, the extent of regressivity (or slight progressivity) has remained approximately constant in most countries. Where progressivity did change (Finland, Poland), contributions rates are low, so that the redistributive effect of these changes is negligible.

51. Figure 9c shows that personal income taxes are clearly redistributive. Yet, in view of the size of average income-tax rates -20 percent or higher in about half the countries shown - the extent of inequality reduction is remarkably small when compared to benefits. Despite a flattening of rate structures (see next section), income taxes have nonetheless become somewhat more progressive in most countries. This is consistent with the strong trend towards greater market-income inequalities, which, in itself, would push up the share of higher-rate taxpayers. In addition, reforms that have broadened the tax base may have resulted in some tax-burden increases for higher-income groups despite the lowering of top rates. Effective income-tax rates faced by all "non-elderly" households on average have, however, declined in most countries. Those two trends (somewhat higher progressivity but reduced size) have had opposite effects on the redistributive capacity of income taxes and have partly cancelled each other out. In combination, they have therefore also produced relatively small changes in overall redistribution in most of the countries shown. Exceptions to this pattern are Australia and Finland, where both progressivity and average tax rates declined (resulting in a less redistributive income tax). In Demark (between the mid-1980s and the mid-1990s) and Germany (after the mid-1990s), the income tax became significantly more redistributive. In Switzerland and the United Kingdom, reduced progressivity has cut the (already low) redistributive effect of income tax approximately in half.

22. As noted in Box 2, the results do not permit an exact quantitative comparison of inequality-reducing effects between benefits, contribution and taxes. 
Figure 9. Drivers of redistribution: Progressivity and size of transfers and taxes

(a) Social transfers, years as indicated

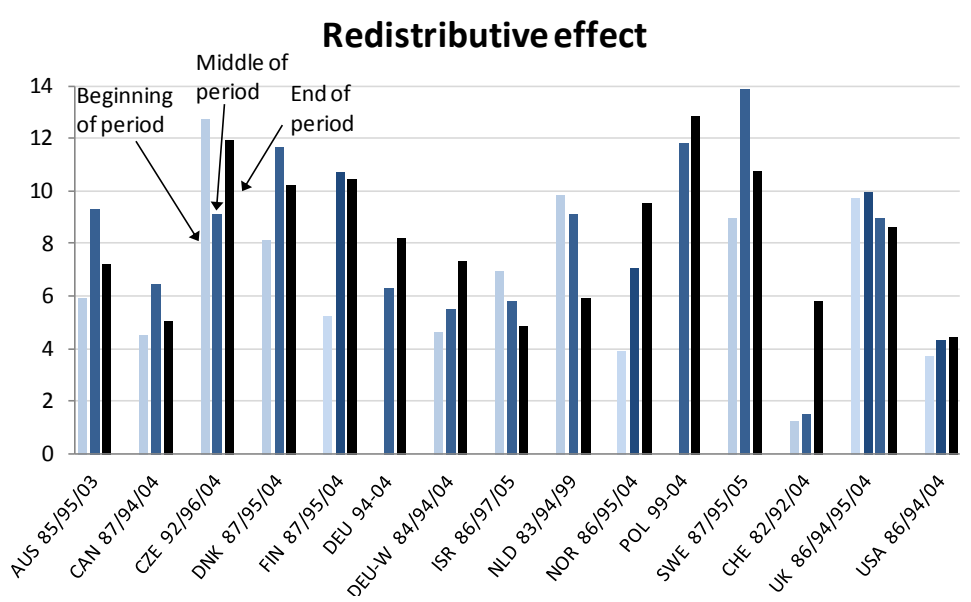

Size (inverted scale)

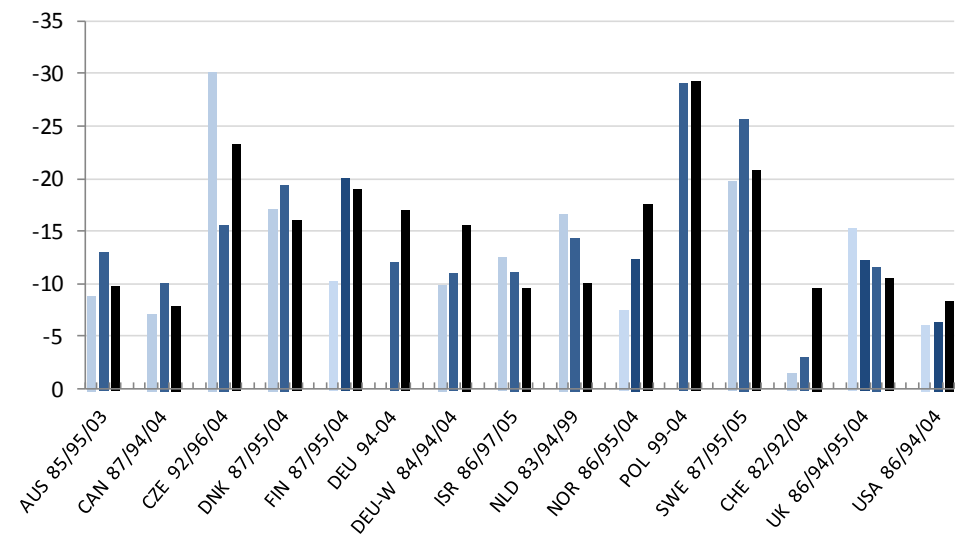

Progressivity (inverted scale)

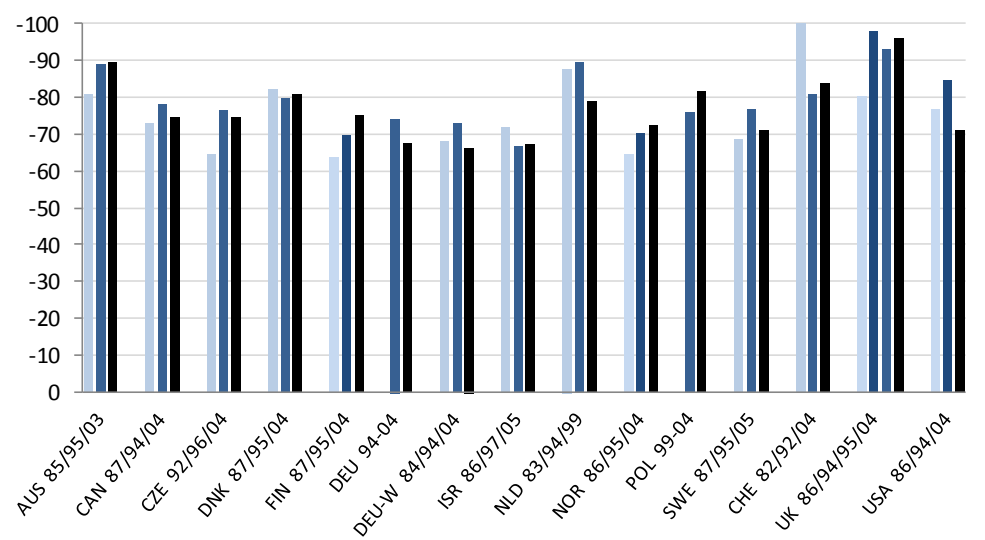

Notes: See bottom of Panel c.

Source: Authors' calculations using data from the Luxembourg Income Study. 
Figure 9 (continued)

(b) Social security contributions paid by households, years as indicated

\section{Redistributive effect}

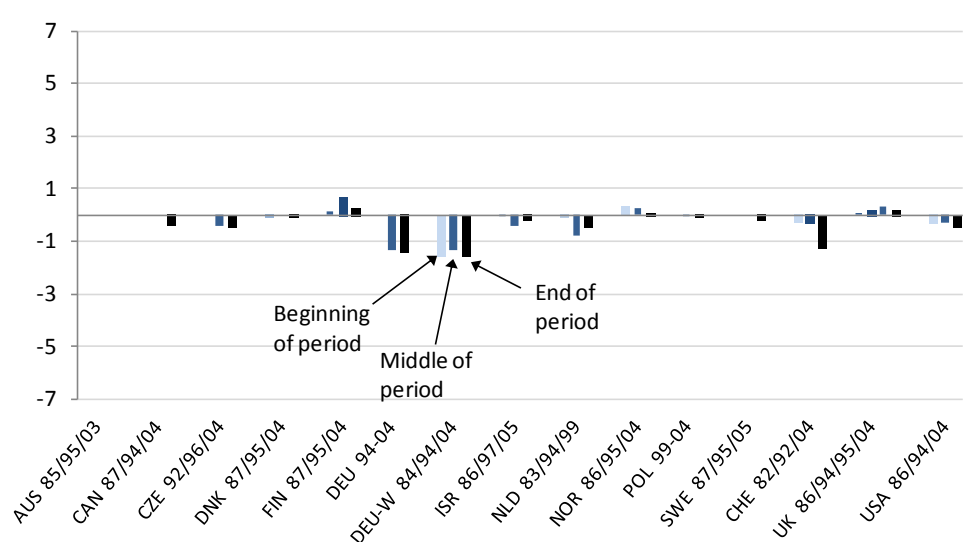

Size

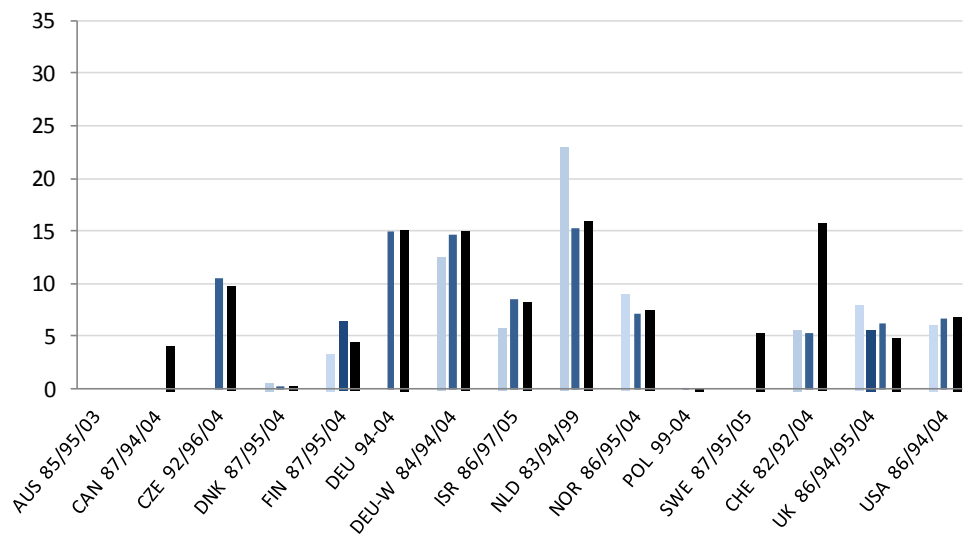

Progressivity

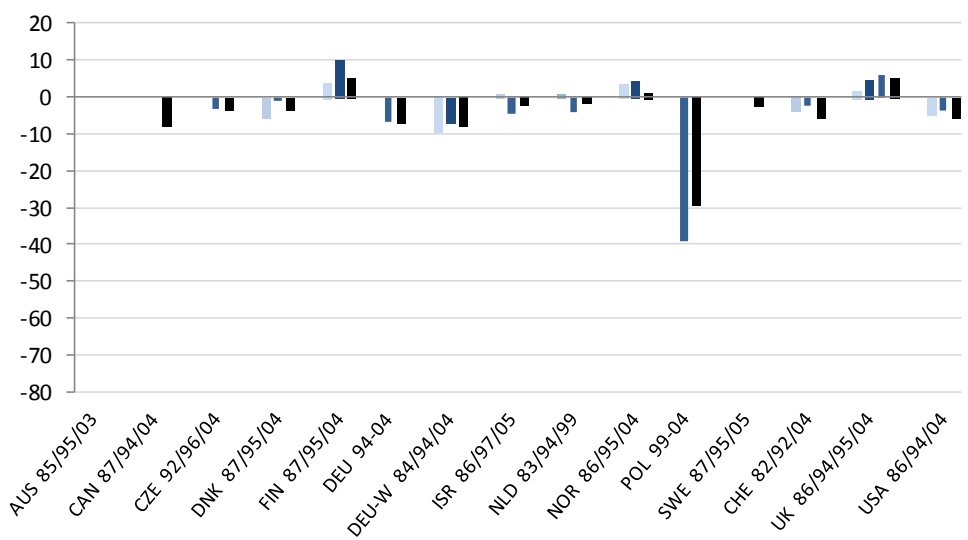

Notes: Notes: See bottom of Panel c.

Source: Authors' calculations using data from the Luxembourg Income Study. 
Figure 9 (continued)

(c) Personal income tax, years as indicated

Redistributive effect

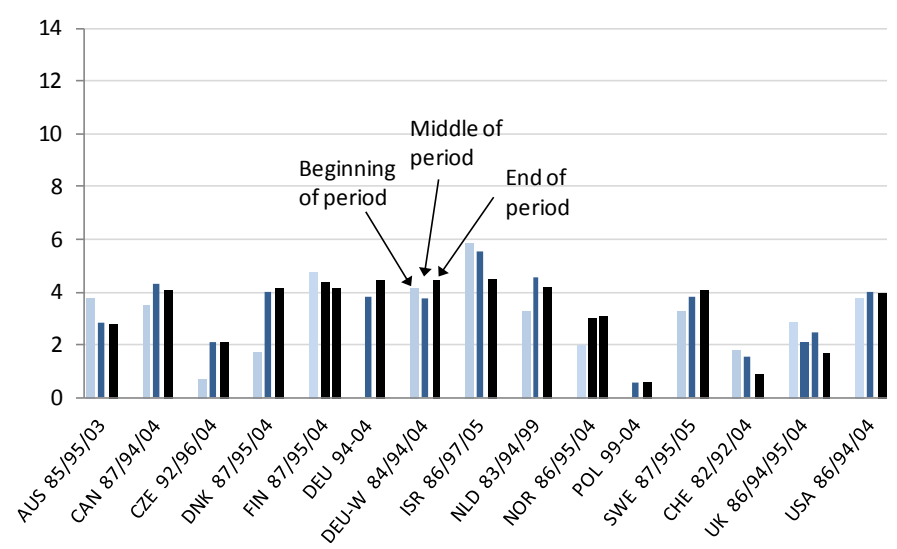

Size

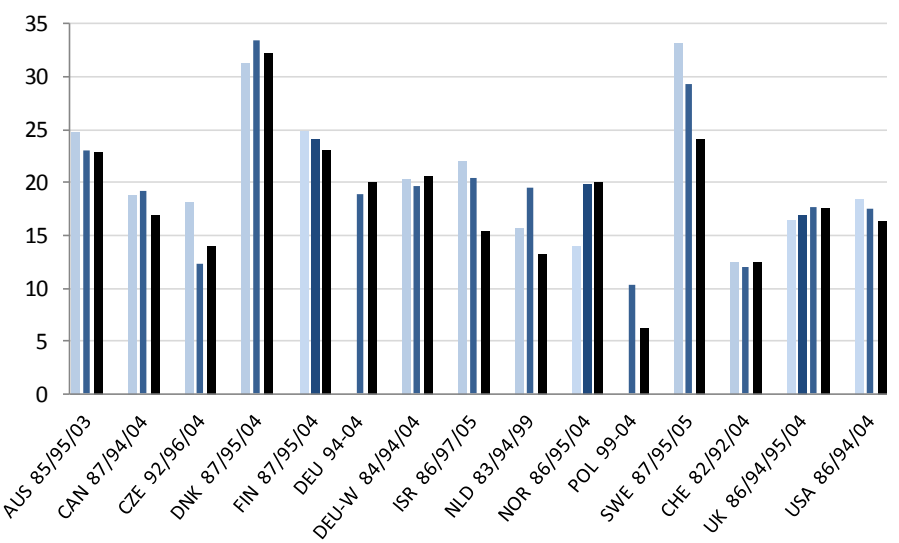

Progressivity

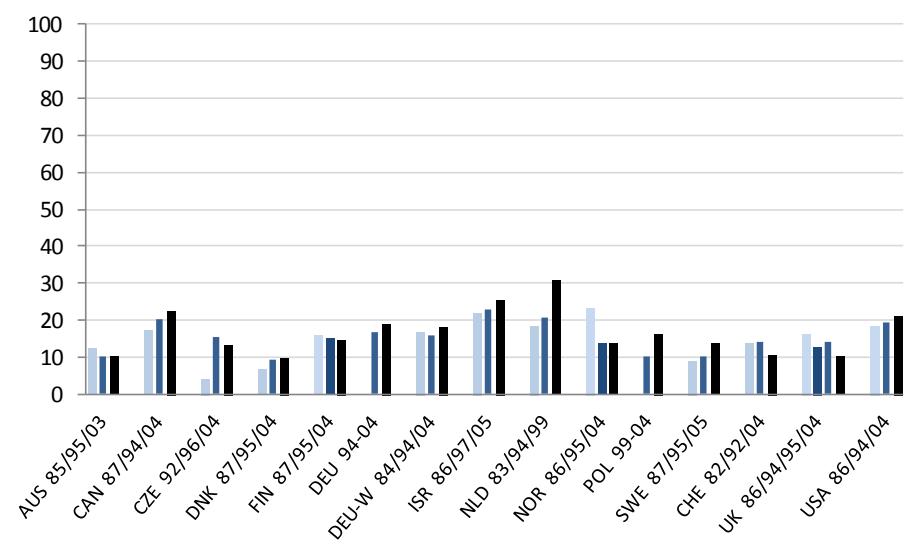

Notes: See Box 2 and Tables 4 and 5 for definitions, measurement choices and statistical breaks in the series. The redistributive effect is the difference between the Gini coefficients before and after the respective tax or benefit. "Size" is the average ratio of the respective tax (or negative benefit) over pre-tax/benefit income. Progressivity is the Kakwani measure for the respective tax or benefit.

Source: Authors' calculations using data from the Luxembourg Income Study. 
52. The benefit indicators shown in Figure 9 are for all cash transfers taken together. Due to data limitations, it is often difficult to distinguish between individual benefit programmes and, hence, draw more specific conclusions about their relative importance has evolved over time. One can, however, analyse results for different population groups. Both policy reforms and cyclical drivers of labour-market activity impact differently on older workers in particular. It is may therefore be informative to look separately at results for those aged below and above 55 . Benefit size has been shown to be the main driver of the redistributive effect of transfers and the tax-benefit system as a whole. Table 7 shows average benefit payments received by households headed by younger and prime-age individuals (15-54) as a percentage of the payments received by all "working-age households" (15-64).

53. Benefit rates for the 15-54 year-olds are lower than for the 54-64 year-olds in all countries. In several of them, the rates turn out to be much lower once older working-age people are excluded (Czech Republic, Finland, Poland, Switzerland). These ratios reflect the generosity of disability and earlyretirement payments relative to unemployment and family benefits, as well as the incidence of unemployment and inactivity among different age groups. Importantly, and despite reform attempts to reduce benefit dependency among older workers, ratios of benefits received by younger relative to older working-age groups have declined since the mid-90s in most countries. Where this is the case, the earlier finding of a declining redistributive capacity of tax-benefit policies appears to hold especially for those aged under 55. The next section takes a closer look at recent policy reforms with an impact on this age group in particular.

\section{Table 7. Benefits paid to different age groups}

Average benefit rate, $15-54$ in percent of 15-64

\begin{tabular}{|c|c|c|c|c|c|c|c|c|c|c|c|c|c|c|c|}
\hline & $\begin{array}{c}\text { AUS } \\
85 / 95 / 03 \\
\end{array}$ & $\begin{array}{c}\text { CAN } \\
87 / 94 / 04 \\
\end{array}$ & $\begin{array}{c}\text { CZE } \\
92 / 96 / 04 \\
\end{array}$ & $\begin{array}{c}\text { DNK } \\
87 / 95 / 04 \\
\end{array}$ & $\begin{array}{c}\text { FIN } \\
87 / 95 / 04 \\
\end{array}$ & $\begin{array}{l}\text { DEU } \\
94 / 04 \\
\end{array}$ & $\begin{array}{l}\text { DEU-W } \\
84 / 94 / 04 \\
\end{array}$ & $\begin{array}{c}\text { ISR } \\
86 / 97 / 05 \\
\end{array}$ & $\begin{array}{c}\text { NLD } \\
83 / 94 / 99 \\
\end{array}$ & $\begin{array}{c}\text { NOR } \\
86 / 95 / 04 \\
\end{array}$ & $\begin{array}{l}\text { POL } \\
99 / 04 \\
\end{array}$ & $\begin{array}{c}\text { SWE } \\
87 / 95 / 05 \\
\end{array}$ & $\begin{array}{c}\text { CHE } \\
82 / 92 / 04 \\
\end{array}$ & $\begin{array}{c}\text { UKG } \\
86 / 94 / 95 / 04 \\
\end{array}$ & $\begin{array}{c}\text { USA } \\
86 / 94 / 04 \\
\end{array}$ \\
\hline year 1 & 90.7 & 93.6 & & 95.0 & 93.3 & & 79.6 & 98.6 & 86.6 & 85.5 & & 83.5 & 42.8 & 94.9 & 86.9 \\
\hline year 2 & 89.3 & 94.1 & 77.4 & 91.1 & 102.3 & 78.5 & 74.6 & 102.0 & 80.1 & 100.0 & & 97.2 & 67.8 & 91.8 & 89.6 \\
\hline year 3 & & & 75.3 & & & & & & 76.0 & & 70.9 & & & 100.0 & \\
\hline year 4 & 93.4 & 93.4 & 75.9 & 92.7 & 81.7 & 90.3 & 88.6 & 93.4 & & 97.3 & 65.9 & 97.6 & 75.9 & 96.5 & 85.9 \\
\hline
\end{tabular}

Notes and sources: see Figure 9. Age brackets relate to household head. For Sweden, the lower age cut-off is 25 instead of 15.

\section{THE ROLE OF POLICY REFORMS}

54. The analysis based on household data shows whether different parts of the tax-benefit system have become more or less redistributive, but they do not reveal why this has happened. In particular, looking at inequality before and after accounting for taxes and benefits does not allow separating the effects of policy initiatives on the one hand, and changes in market-income inequality (e.g., because of changing employment patterns) on the other. This section attempts to shed more light on the role of specific policy changes.

\subsection{The reach of benefit systems: more or less encompassing?}

55. Out-of-work benefits provide support to people who may otherwise have very low incomes or no income at all. This is the primary reason why the benefit system in its entirety is more redistributive than 
direct taxes. Unemployment benefits, but also other out-of-work programmes (notably disability benefits which now account for a larger share of social spending, but are less important for younger and prime-age workers).

\section{Figure 10. Unemployment benefit recipiency}

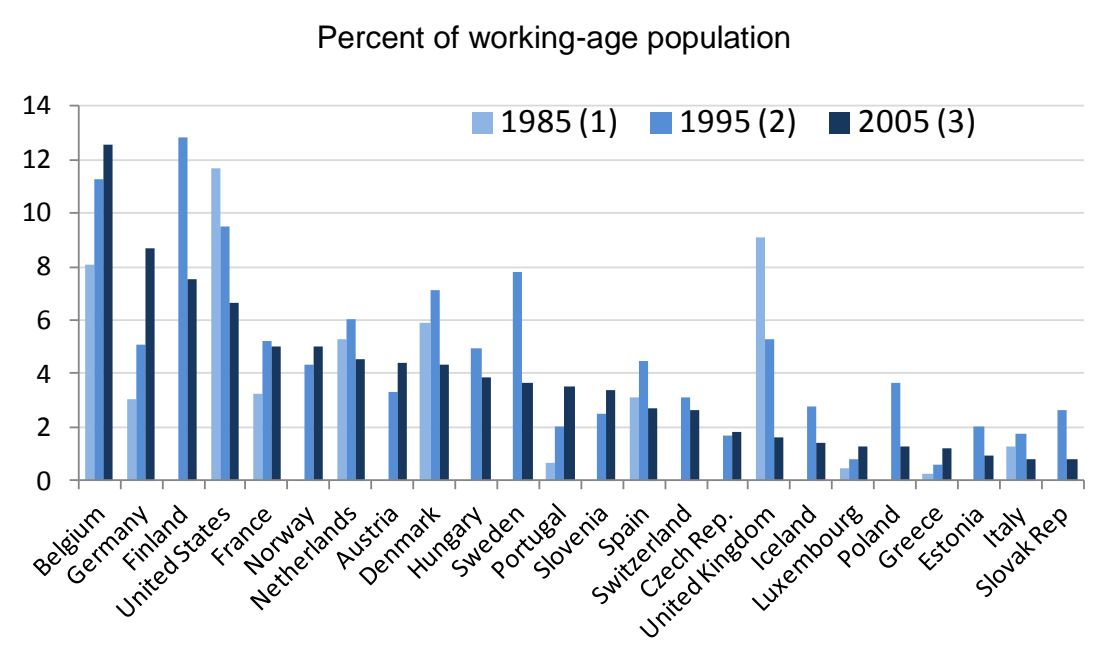

(1) Portugal: 1986, Spain: 1987, United States: 1992.

(2) Hungary and Switzerland: 1996, Czech Republic, Estonia, Poland: 1997, Slovak Republic: 1998.

(3) Netherlands: 1999, Spain: 2004

Source: European Labour Force Surveys and Current Population Survey (US). For definitions and limitations see Immervoll et al. (2004).

56. Detailed benefit recipiency data for all relevant out-of-work benefits are currently not available. ${ }^{23}$ However, although questions differ across surveys and data are therefore not fully comparable across countries, labour force surveys (LFS) provide useful evidence on the number of people receiving unemployment benefits. ${ }^{24}$ They also contain some information on recipient characteristics, notably on their labour-force status. Figure 10 plots LFS data on the overall proportions of working-age individuals receiving unemployment benefits at different points in time. While recipiency rates have changed little in a few countries (Luxembourg, Switzerland, as well as Czech Republic, France and Slovenia since the mid1990s), most see major changes over the period. Rates of benefit receipt rose strongly in Belgium, Germany and Portugal and fell in Italy, United Kingdom and, since the mid-1990s, in Spain, the United States, and in most Nordic countries (not in Norway).

57. Two important determining factors of these trends are simply the extent and patterns of unemployment. But in addition, changing eligibility rules, including the enforcement of job-search conditions and other behavioural requirements, also affect recipiency rates. Figure 11 indicates that the

23. Measuring the number of individuals receiving out-of-work benefits raises a number of conceptual issues (such as determining the appropriate reference time period and avoiding double-counting, see, e.g., Carcillo and Grubb, 2006). They are especially difficult to address in a comparative context where data sources and definitions differ between countries, and often between benefit categories. When measuring benefit receipt at the household level, the challenges and data requirements are greater still.

24. Immervoll et al., 2004 (Section 3) provide details on the questions used in the different surveys, and discuss comparability issues. These issues are arguably less problematic when, as in the present study, the main interest is in changes over time. 
shares of unemployed reporting benefit receipt have dropped in a majority (two thirds) of the countries shown, while only a few recorded significant increases. Such changes in recorded benefit accessibility and coverage can result from a changing composition of the unemployed group. For instance, because of difficulties in meeting relevant employment or contribution conditions, the number of young people without a job can influence coverage rates. Interestingly, however, the middle and lower panels of Figure 11 suggest that coverage has generally moved in the same direction for those with and without prior work experience. Other relevant factors include the dynamics into and out of unemployment. For instance, high inflow rates into unemployment at the beginning of a recession can increase the share of benefit recipients among the stock of unemployed as recent job losers are more likely to qualify for benefits. A rising share of long-term unemployed can have the opposite effect if large numbers of unemployed are running out of entitlements. Across countries, a changing incidence of long-term unemployment cannot, however, explain a pattern of declining benefit coverage. Between the mid-1990s and the mid-2000s, the proportion of long-term unemployment fell significantly in most countries, with 53 percent (36 percent) unemployed over 6 (12) months in 1994, and 45 percent (32 percent) in 2006 on average in the OECD area.

58. More likely driving factors of declining coverage rates during this period are shortening average employment spells and less continuous work histories, as well as, in some but not all countries, increasing shares of temporary employment and other types of non-standard work. ${ }^{25}$ Depending on entitlement conditions for unemployment benefits, growing shares of workers may remain unprotected if non-standard work patterns become more common. Large shares of non-standard workers are the result of longer-term structural changes in the labour market. Where they are increasing, gaps in unemployment insurance systems are likely to become evident. Non-standard workers may be excluded from benefit receipt by law (e.g., the self-employed in most countries, including the so-called "falsely" self-employed) or de facto because they are less likely to meet contribution requirements or satisfy other relevant eligibility criteria (e.g., temporary or part-time workers). ${ }^{26}$ One objective of the summary of policy trends in the next section is to examine whether policies have adapted to these changes (e.g., by making it easier for non-standard workers to qualify for benefits).

25. See Statistical Annex of the OECD Employment Outlook for data on the incidence of long-term unemployment and temporary employment.

26. Among OECD countries in the mid-2000s, initial employment or contribution requirements for entitlement to unemployment insurance benefits (UI) were strictest in the Slovak Republic (three years), Turkey (600 working days) and the United Kingdom (two years, but no requirement for unemployment assistance), followed by Belgium, Poland and Spain (468, 365 and 360 working days, respectively), as well as Austria, the Czech Republic, Denmark, Germany, Italy, Sweden and Switzerland (all 12 months). On the other end of the spectrum, prime-age workers in nine countries satisfy both contribution and employment requirements with 6 months of full-time work or less (Canada, France, Greece, Iceland, Japan, Korea, Netherlands, Norway, United States). There are no employment or contribution conditions for (meanstested) unemployment benefits in Australia and New Zealand. In addition to work-history requirements, benefit rules may however stipulate other conditions which may preclude access to unemployment insurance for part-time workers, even if they have long and relatively stable work records. For instance, in a number of US States, minimum requirements on previous earnings can make part-time low-paid workers ineligible for unemployment insurance. 
Figure 11. Unemployment benefit coverage

(a) All unemployed, in percent of ILO unemployed

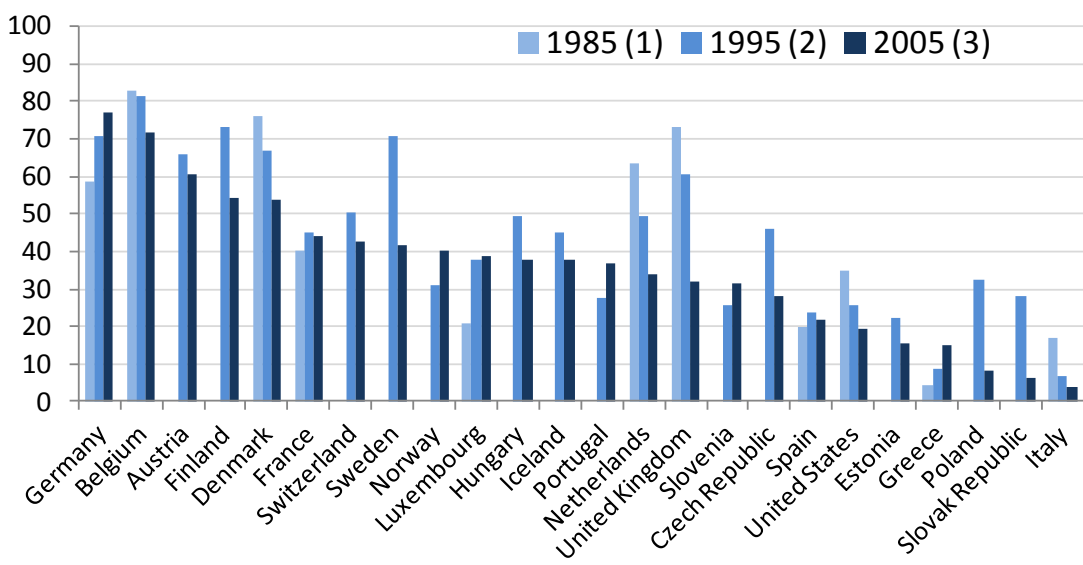

(b) Unemployed with previous work experience, in percent of ILO unemployed

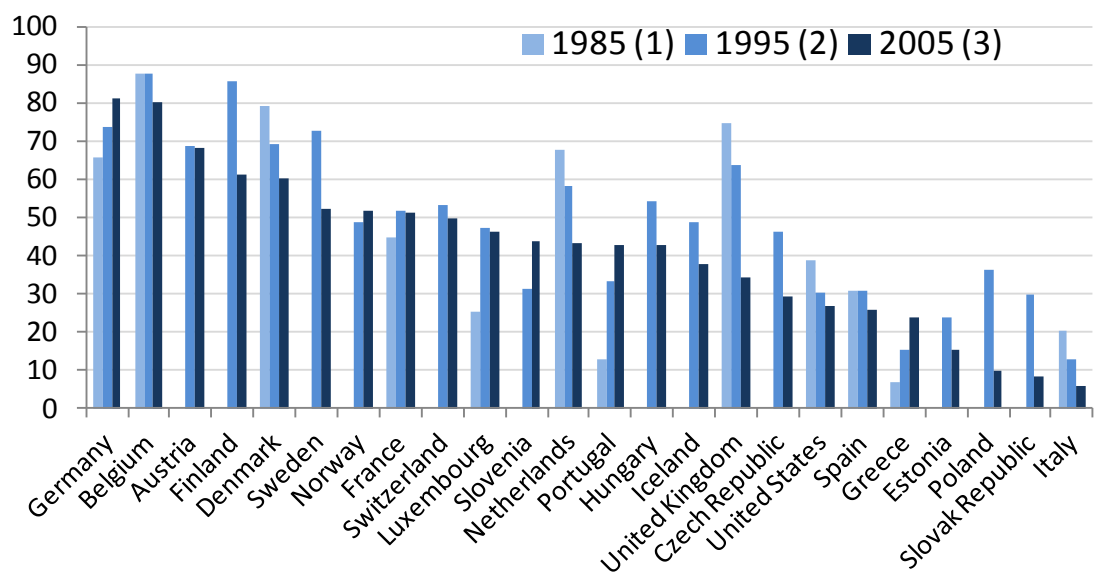

(c) Unemployed without previous work experience, in percent of ILO unemployed

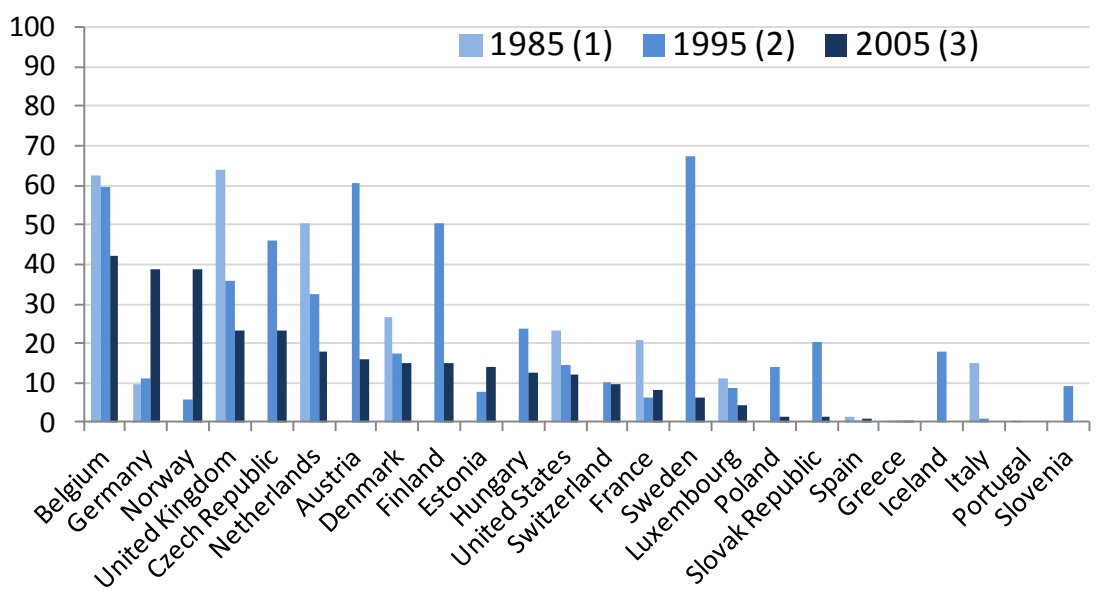

Notes and sources: See Figure 10 


\subsection{Key features of redistribution systems and major policy changes in selected countries}

59. Annex Tables A2 to A6 summarise some of the main policy changes between the mid-1980s and the mid-200s for a subset of 10 OECD countries. ${ }^{27}$ In order to show the evolution of benefit amounts and other policy parameters in relation to the income distribution, all monetary amounts are expressed in percent of the average wage of a production worker in the manufacturing industry (Average Production Worker, APW). ${ }^{28}$ In an attempt to highlight the distributional consequences of policy changes, benefit provisions that were made less generous are shown in black, while shaded cells indicate changes that tend to result in higher entitlements (Tables A2-A5). Categorising tax-related changes (Table A6) in a similar fashion is less straightforward and was therefore not attempted.

60. For this subset of countries, initial eligibility conditions for unemployment benefits appear to have become more demanding since the mid-1980s (Annex Table A2). For people with short or interrupted employment records, reforms in Finland, France and the United Kingdom tended to make it harder to qualify for unemployment insurance (UI). Most countries also reduced benefit levels, either through discrete policy changes, or by not fully adjusting ("indexing") benefits in line within-work earnings (Austria, Czech Republic, Finland, Japan, United Kingdom as well as Germany for jobseekers without children). While some countries raised entitlements for some or all recipients (longer benefit durations in Austria and Finland, somewhat higher benefit amounts in United States/Michigan), none appear to have lowered the barriers to access the benefit system.

61. For jobseekers not qualifying for insurance benefits, assistance programmes are the main form of income support. Benefit amounts tend to be both lower and, because they are means-tested on family income, more targeted to low-income families. Unemployment assistance benefits (UA, Annex Table A3) are, however, sometimes only available as follow-up support once insurance benefits expire (Austria, France in 1985 and Germany prior to 2005). In other countries, they may also be payable to jobseekers who do not qualify for insurance benefits in the first place (Finland, France, United Kingdom). In Australia (as well as in New Zealand, not included in the tables), they are the only form of unemployment benefit. As unemployment support, such assistance benefits are only available to those who are available and actively looking for work. Eligibility is sometimes also conditional on previous employment. Benefit durations may be limited, but more often are not. Compared with UI, changes since the mid-1980s to unemployment assistance rules were fewer and smaller. Benefit amounts tended to become less generous, while employment or contribution requirements (where they exist) changed little. A major exception is

27. The OECD collects and publishes information on the main tax and benefit policy parameters on an annual basis, with data going back to 2001 (see www.oecd.org/els/social/workincentives). For the purpose of the present study, an attempt was made to assemble data for 1995 and 1985 for selected countries in a similar format. This section draws on the resulting policy database, and on various editions of the "Benefits and Wages" series, to summarise relevant policy changes since 1985. To keep the discussion focussed, it is limited to able-bodied prime-age workers. In particular, sickness, disability and early retirement benefits are beyond the scope of the present exercise; they are discussed in the OECD series Sickness, Disability and Work (see www.oecd.org/els/disability) and in in-depth country reviews on the situation of older workers (www.oecd.org/olderworkersforum).

28. For a comparison over a long time period, the choice of the APW as a common reference is defendable, but not ideal. The obvious advantage is that long APW time series are available and that the concept is, on a technical level, consistent across countries. However, the proportion of workers employed in the manufacturing sector varies both between countries and over time. In particular, women are underrepresented so that the APW has become less representative over time - and less useful as a broad earnings benchmark as a result. In recent work, the OECD is therefore using the more representative average wage (AW) measure. However, the AW series only go back to the early 2000s. For details, see D'Addio and Immervoll (2010), who also provide AW-consistent earnings distribution data and breakdowns by sex. 
Germany, where unemployment and social assistance for jobseekers were merged into one single programme in 2005 (the Unemployment Benefit II). For long-term unemployed with relatively high previous earnings, this resulted in substantially lower benefit amounts. While the benefit can now be received by jobless people without any employment record, this has not made benefits more accessible or more generous as these individuals had access to social assistance (paid at similar rates) before the reform.

62. Social assistance provisions (SA, Annex Table A4) have remained largely unchanged, although benefit levels in some countries have not kept up with earnings growth so that social assistance recipients are likely to have slipped further down in the income distribution. However, SA programmes are often administered at a regional or local level, resulting in considerable variation in legal rules or guidelines that are difficult to capture in these summary tables. Regional or local authorities may also provide supplementary programmes on top of those which are nationally co-ordinated (e.g., General Assistance in US States, see Gallagher et al., 1999). Finally, benefit offices and caseworkers sometimes have considerable room for discretion (e.g., by awarding support in special circumstances). As a result, a summary of legal provisions is unlikely to fully capture changes "on the ground". Budgetary pressures are one factor that can drive differences in access to these programmes which are not apparent from an inspection of formal eligibility rules. Not all programmes have an entitlement character, and some recipients may be excluded despite being eligible. Even where there are legal entitlements, budgetary pressures can make access more difficult in practice and, hence, depress effective take-up rates (e.g., if administrative staff are unable to provide timely service when faced with a steep increase in the number of claims). ${ }^{29}$

63. Since the 1990's, social policy debates in OECD countries have increasingly emphasised the need for "active" and "activating" support. Although the balance varies widely between countries and policy areas, such support includes assistance towards regaining self-sufficiency, allied to the possibility of benefit sanctions if a client's own efforts are considered inadequate. It is important to stress that some types of activation measures can have a similar effect on benefit recipiency patterns as tightening eligibility criteria. Attempts to rebalance policies from passive income assistance towards strengthening selfsufficiency have, at least in principle, been a central element of reform initiatives across a broad range of social policy areas. They were the main focus of reforming assistance benefits in a number of countries, including Australia, Netherlands, United Kingdom, United States and several Nordic countries. There is much controversy in the evaluation literature about the successes of these efforts. Those who are, in some sense, closest to the labour market are better positioned to benefit from work-oriented support. In contrast, other social policy clients, including recipients of social assistance and other benefits of last resort, have frequently been shown to experience considerable difficulties in achieving lasting labour market integration and adequate incomes. ${ }^{30}$

64. Although activation policies are not covered in this section's short summary, Tables A2 to A4 do show that means-tests and rules on permissible work activities for benefit recipients were often made more employment-friendly. Across the three different types of out-of-work support, benefit phase-out rates were frequently reduced, or greater portions of earnings disregarded in the means-test (UI in the Czech Republic, Finland and France, UA in Australia, Finland and Germany, SA in Finland and France). These changes are not only significant for their effects on work incentives. In the case of means-tested benefits, a

29. For understanding the changing role of SA in government redistribution, it would therefore be particularly important to gauge benefit-claiming behaviour and patterns. Unfortunately, while high-quality data exist for some of the more centralised programmes (e.g., for the US Food Stamp programme, see USDA, 2010), comparable information on SA benefit recipiency patterns is currently not available across countries.

30. Activation policies are the subject of ongoing OECD policy reviews and other analytical work (see www.oecd.org/els/employment/almp), while an overview of activation requirements for recipients of minimum-income benefits is given in Immervoll (2010). 
less rapid withdrawal of benefits can also convert a programme from being mostly an out-of-work safety net to a broader support programme that extends income supplements to low-earning individuals and their families. By extending the benefit withdrawal range higher up the earnings distribution, these reforms strengthen redistribution by reducing net income differentials and, hence, inequality, in some parts of the distribution. At the same time, such reforms can weaken the financial payoff from increasing earnings further, giving rise to the possibility of so-called "low-income traps" or "poverty traps" for some recipients. Similar issues can arise for employment-conditional in-work benefits although these transfers are generally more effective at accentuating the income difference between working and not working. Since the mid-1980s, support for low-wage workers has been expanded substantially in the United States (Earned Income Tax Credit) and the United Kingdom (Family Credit, later Working Families Tax Credit, now Working Credit), especially for families with children (both FC and WFTC were only available to families with children). As a result, in 1999, the EITC reduced (official) child poverty in lone-parent households by 4.5 percentage points to $25.1 \%$ while, in 1990, the reduction was less than 1 percentage point (House Committee on Ways and Means, 2004, Table H-21, cited in Haskins, 2006). The UK inwork benefits were significantly more generous than the EITC, with per-family expenditures on average about four times as high in the early 2000s. While many other OECD countries have introduced some form of in-work benefit in recent years, their sizes and their redistributive impact are currently small so they are not covered here in detail (see Immervoll and Pearson, 2009).

65. Unlike out-of-work benefits discussed above, other types of child-related support (family benefits, Annex Table A5) have also become significantly more generous since the mid-1980s. In Australia, Germany and Japan, benefit amounts per child have risen more strongly than earnings levels, while the United Kingdom and United States have introduced new child-related tax credits. But while the UK credit also benefits families on the lowest incomes (it is refundable and not counted as income in relevant means-tests), the US credit does not (it is counted as income in means-tests and is only partially refundable). Re-balancing support in favour of families with more children (who are more likely to face low incomes and relative income poverty) tends to make family benefits more redistributive (Austria, Italy). A few countries have increased the maximum age limit for child-related benefit payments and one country (Japan) reduced the limit between 1985 and 1995 (the limit was subsequently raised again though not to its original level).

66. Personal income taxes (PIT) are the most thoroughly documented element of redistribution policy reforms (Hagemann et al., 1988; Pechman, 1987, 1988; OECD, 1986, 1993, 1995). The most important trends identified in these studies can be seen from the policy parameters summarised in Table A6. These include a flattening of rate schedules and a move towards individual taxation. For a given revenue, less progressive tax schedules unambiguously reduce the redistributive power of income taxes. In particular, lower rates at the top will widen the net income distribution, unless the reform is accompanied by measures that broaden the tax base to an extent that prevents average tax payments for rich families from falling. Without accounting for any tax-base changes, lower top income-tax rates exacerbate the widening gap between incomes at the bottom and the top of the distribution. Reductions in top rates were steepest in Japan (from 70 to 37 percent), Italy (65 to 43), United Kingdom (60 to 40), and France (65 to 48). The flattening of schedules mostly concerned higher income ranges (Australia, Austria, Finland, France, Germany, Japan, United Kingdom, United States). In the Czech Republic (1995-2005) the tax schedule flattened only at very high income levels (in excess of 500 percent of the average wage). Failure of tax thresholds to keep pace with wage growth has effectively compressed the tax schedule (making it steeper) at low-to-moderate income levels (e.g., Australia and the United States).

67. While a reduced differential between top and bottom rates makes income taxes less progressive over some income ranges, this does not necessarily render the PIT less progressive or redistributive as a whole if other measures are taken in parallel. In particular, exempting a larger proportion of the population from income taxes altogether (e.g., by widening the zero-rate bracket as in Austria, or by increasing the 
tax-free allowance as in Italy) could actually make PIT more, rather than less, progressive (Keen et al., 2000). The larger number of tax-exempt low-income families is one possible reason why the progressivity measures reported for most countries in Section 4 (Figure 9) did not show a more noticeable fall between the mid-1980s and the mid-2000s. However, the most important explanation for this pattern is probably that pre-tax income inequality rose substantially in most countries, pushing up the gap between income-tax burdens faced by different income groups. To some extent, this offset the more generous tax treatment of the rich that can result from flatter tax schedules. In summary, and as shown earlier in Figure 9, incometax burdens in more than half the countries considered did not become more progressive despite widening income gaps between rich and poor. In these countries, the negative impact on overall progressivity of schedule-flattening therefore appears to have matched or outweighed the automatic inequality-dampening effect built into progressive tax systems (as well as any measures that were aimed at broadening the tax base for higher-income taxpayers).

68. A second long-run trend is a move away from joint to individual income taxation. However, among the countries included in Table A6, only the United Kingdom has made this switch since the mid1980s, while the Czech Republic has moved in the opposite direction. ${ }^{31}$ The choice between the different assessment units is relevant for a number of - partially competing - policy objectives. For instance, Rosen (1977) has already shown that an income tax cannot be progressive and also achieve both horizontal equity with respect to family income (same tax burden for families with the same total income) and marriage neutrality (same tax burden regardless of marital status). In recent years, the problematic incentive structure of joint tax assessments has often been emphasised as they result in high marginal tax rates for second earners who are known to respond more strongly to financial incentives than primary earners. Recent work covering $15 \mathrm{EU}$ countries shows that shifting tax burdens from second to primary earners brings large welfare gains (Immervoll et al., forthcoming). However, as long as income taxes are progressive, assessing taxes based on family incomes is superior in terms of reducing the inequality of income as measured in this study. From a pure equity perspective, and ignoring employment gains, moving from a joint system to individual taxes would therefore result in less redistribution. However, "joint elements" (e.g., tax concessions whose value depends on joint, rather than individual income) also exist in tax systems that are nominally individual-based, and these elements have also been the subject of policy reforms. ${ }^{32}$ Without detailed modelling (see below), it is difficult to evaluate how changes in the tax assessment of family incomes have altered the inequality-reducing properties of the income tax.

69. Social contributions can be as sizable as income taxes but, as shown earlier in Figure 9b, they do not have a big effect on cross-sectional inequality. Moreover, apart from level changes (see revenue data in Table 3 and average tax rates in Figure 9), relevant rules have changed little over the time period. A table with summaries of 2005 social security contribution schedules in most OECD (and also of other benefits and taxes considered in this section) is available in OECD (2007a) and through www.oecd.org/els/social/workincentives.

\subsection{Generosity of support for the unemployed}

70. The discussion of policy changes has shown that there was a general tendency toward reducing the generosity of unemployment benefits across OECD countries for which information is available. This has notably been the case since the mid-90s. In six of the eight countries where unemployment benefits appear to have tightened, at least one element of unemployment benefits became more generous. In

31. Belgium has also moved to individual taxation (see Decoster and van Camp, 2001). In 2005, a total of 11 out of 30 OECD countries taxed (married) couples jointly: those shown in Table A6, plus Ireland, Luxembourg, Poland, Portugal, Switzerland and, on an optional basis, Norway and Spain.

32. Similarly, joint income taxes are rarely fully neutral with respect to how incomes are distributed in the household (i.e., they contain "individual elements"). 
France, for example, the maximum benefit duration in the unemployment insurance programme was reduced (Table A2, column 4) while time-dependent reductions in payment rates were abandoned (column 5). Similarly, reductions in the value of benefit ceilings (column 8) occurred in the two countries (Italy and the United States) where statutory benefit replacement rates were made more generous.

71. Net replacement rates (NRR) are a useful way of quantifying the net effects of these changes. These indicators express the net incomes of unemployed people relative to those in work. This measure of relative income maintenance during unemployment accounts for changes in the net incomes of both working and non-working individuals. They are therefore particularly well-suited for an assessment of how policy changes have impacted on relative inequality measures. A negative change of NRR points to incomes of the unemployed falling behind relative to those in work.

72. Figure 12 provides a strong indication of reduced cash support for the unemployed between 1995 and 2005. Seven of the 10 countries recorded declining NRRs. The largest falls were recorded in countries where, relative to average earnings, the generosity of both unemployment benefits (UI and UA) and social assistance (SA) were reduced: Finland (UI, UA and SA), Germany (SA and merging of UA and SA) and the Czech Republic (UI and SA). Finland and Germany saw the biggest reductions in net replacement rates. A decomposition of these changes (not reported) shows that in Germany, and to a lesser extent Finland, effective tax burdens on employment incomes were reduced at the same time, which further widened the gap between incomes in-work and out-of-work.

\section{Figure 12. Net replacement rates of unemployment support}

\section{Average over a long unemployment spell (60 months of unemployment), in percent}

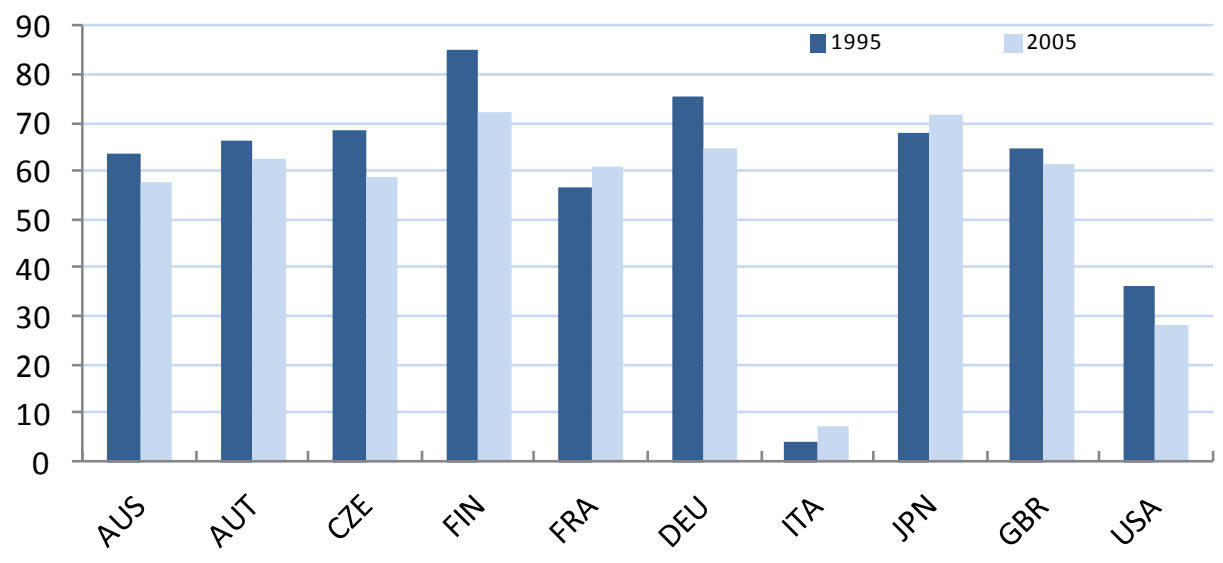

Notes: The synthetic NRR is calculated as an unweighted average of NRRs in each month of a long unemployment spell (60 months), at two levels of previous earnings (67\% and $100 \%$ of average full-time wages) and for four stylised family types (single persons, lone parents, one-earner couples with and without children). Calculations consider cash incomes (excluding, for instance, employer contributions to health or pension insurance for workers and in-kind transfers for the unemployed) as well as income taxes and mandatory social security contributions paid by employees. In addition to unemployment benefits, minimum-income transfers and or housing-related benefits are available as income top-ups as applicable. Where benefit eligibility is subject to behavioural requirements (such as active job-search or being available for work), these requirements are assumed to be met. Net replacement rates are evaluated for a prime-age worker (aged 40) with a "long" and uninterrupted employment record. . Due to benefit ceilings, net replacement rates are lower for individuals with above-average earnings. See OECD (2007a) for full details.

Source: OECD tax-benefit models (www.oecd.org/els/social/workincentives). 
73. Changes for the unemployed in most countries tended to be less damaging (or, sometimes, more beneficial) for families with children. This is shown in Table 8a. Whether with or without children, oneadult families generally fared better than two-adult families. In Australia, Japan and the United Kingdom, increased out-of-work support for lone parents is evident. In contrast, NRRs for families with children fell more strongly in the Czech Republic, Italy and the United States. Germany and the United States are the only countries where NRRs fell more for lone parent families than for couples with children.

74. The largest relative income drop was generally faced by long-term unemployed jobseekers who mostly rely on unemployment assistance or social assistance for income support (Table 8b). Two exceptions are Italy (where long-term unemployed in Italy already had little or no cash support in 1995) and Japan (where the duration of unemployment insurance benefits was extended). Importantly, these results are for jobseekers who were entitled to unemployment insurance benefits in the first place. Because non-standard workers and others with limited or interrupted employment records often have no access to unemployment insurance, NRR trends for these groups will often have been similar to those faced by the long-term unemployed. In view of the fall in unemployment-benefit coverage rates documented above, minimum-income support for those with no or little other income is likely to have become a more central driver of overall redistribution trends. Income changes for this group are considered in the sections below.

Table 8. Net replacement rates of unemployment support

(a) by family type, in percent

\begin{tabular}{|c|c|c|c|c|c|c|c|c|c|c|}
\hline & \multicolumn{4}{|c|}{ No children } & \multicolumn{4}{|c|}{ Two children } & \multirow{2}{*}{\multicolumn{2}{|c|}{ Average }} \\
\hline & \multicolumn{2}{|c|}{$\begin{array}{l}\text { Single } \\
\text { person }\end{array}$} & \multicolumn{2}{|c|}{$\begin{array}{l}\text { One-earner married } \\
\text { couple }\end{array}$} & \multicolumn{2}{|c|}{ Lone parent } & \multicolumn{2}{|c|}{$\begin{array}{l}\text { One-earner married } \\
\text { couple }\end{array}$} & & \\
\hline & 1995 & 2005 & 1995 & 2005 & 1995 & 2005 & 1995 & 2005 & 1995 & 2005 \\
\hline Australia & 47 & 40 & 72 & 62 & 58 & 59 & 77 & 71 & 64 & 58 \\
\hline Austria & 56 & 51 & 63 & 58 & 70 & 67 & 77 & 72 & 67 & 62 \\
\hline Czech Republic & 44 & 39 & 74 & 61 & 70 & 64 & 86 & 72 & 68 & 59 \\
\hline Finland & 72 & 57 & 90 & 73 & 82 & 73 & 96 & 84 & 85 & 72 \\
\hline France & 48 & 51 & 53 & 57 & 61 & 66 & 65 & 70 & 57 & 61 \\
\hline Germany & 61 & 50 & 73 & 59 & 85 & 74 & 82 & 75 & 75 & 64 \\
\hline Italy & 4 & 7 & 4 & 7 & 4 & 8 & 5 & 8 & 4 & 8 \\
\hline Japan & 49 & 52 & 67 & 72 & 74 & 80 & 80 & 83 & 68 & 72 \\
\hline United Kingdom & 56 & 49 & 67 & 58 & 63 & 65 & 73 & 72 & 65 & 61 \\
\hline United States & 16 & 13 & 23 & 18 & 52 & 38 & 55 & 44 & 36 & 28 \\
\hline
\end{tabular}

(b) by unemployment duration, in percent

\begin{tabular}{|c|c|c|c|c|c|c|c|c|}
\hline & \multicolumn{2}{|c|}{ First year } & \multicolumn{2}{|c|}{ Second and third year } & \multicolumn{2}{|c|}{ Fourth and fifth year } & \multicolumn{2}{|c|}{ Average } \\
\hline & 1995 & 2005 & 1995 & 2005 & 1995 & 2005 & 1995 & 2005 \\
\hline Australia & 64 & 58 & 64 & 58 & 64 & 58 & 64 & 58 \\
\hline Austria & 68 & 64 & 66 & 62 & 66 & 62 & 67 & 62 \\
\hline Czech Republic & 70 & 61 & 68 & 58 & 68 & 58 & 68 & 59 \\
\hline Finland & 87 & 76 & 85 & 72 & 84 & 70 & 85 & 72 \\
\hline France & 74 & 72 & 54 & 62 & 51 & 54 & 57 & 61 \\
\hline Germany & 76 & 69 & 75 & 65 & 75 & 62 & 75 & 64 \\
\hline Italy & 21 & 38 & 0 & 0 & 0 & 0 & 4 & 8 \\
\hline Japan & 70 & 73 & 67 & 71 & 67 & 71 & 68 & 72 \\
\hline United Kingdom & 65 & 61 & 65 & 61 & 65 & 61 & 65 & 61 \\
\hline United States & 51 & 42 & 32 & 25 & 32 & 25 & 36 & 28 \\
\hline
\end{tabular}

Notes: see Figure 12.

Source: OECD tax-benefit models (www.oecd.org/els/social/workincentives). 


\subsection{Gainers and losers of tax-benefit reforms across the earnings distribution}

75. This section uses the policy information summarised above to identify the effects of policy reforms over the 1995-2005 period at different points in the income distribution. The best way to do this is to calculate tax burdens and benefit entitlements for representative samples of households for different periods. This permits straightforward identification of the relative contribution of policy changes and trends in market-income inequality on redistribution. Box 3 provides an illustration of such an approach using data for the United States. Unfortunately, a comparative analysis using this approach for a larger number of countries is currently not feasible as the required microsimulation models are not readily available, or do not cover the time-period of interest.

76. This section therefore uses a less data-intensive approach, which calculates the effect of policy changes on a range of different model families. The calculations rely on the OECD's tax-benefit models. While this simulation method does not account for differences in population structure and earnings inequality across countries, it can isolate the effect of policy reforms for selected families and earnings levels. It is therefore a useful complement for the earlier analysis of household income data which necessarily mixes the effects of policy and "other" changes. The advantage of the simulation is that it can hold "everything else" constant (unemployment levels, market-income inequality, household composition, etc.), and focuses on the role of policy changes alone. For instance, it can show whether families at the bottom, middle and top of the income distribution are now better or worse off than they would have been with unchanged policies. This way of comparing the net effect of redistribution systems between different periods permits pin-pointing "gainers" and "losers" of policy reforms. The approach is an extension of OECD (2008b). Results are shown for the same 10 OECD countries that were included in the above summary of policy changes. ${ }^{33}$

\section{Box 3. Isolating the direct effect of policy reforms: An illustration for the United States.}

Showing the direct effects of policy reforms on measured redistribution requires holding everything else constant. To do this, one needs to derive a redistribution measure using the same population and distribution of market incomes before the reform (at time $t_{0}$ ) and after the reform (e.g., at time $t_{1}$ ). Because populations change at the same time as policy, such measures are not directly observable. They can, however, be calculated using microsimulation models as these models can apply policy rules from different years to the same population.

Formally, one might consider a tax-benefit function $d$ representing the rules and structure of the tax-benefit system (e.g., benefit eligibility conditions and marginal tax, contribution and benefit withdrawal rates) and a vector $p$ accounting for all monetary parameters (e.g., tax-band limits, tax credits, contribution ceilings, benefit amounts). The distribution of after-tax income can then be represented by $d_{i}\left(p_{j}, y_{k}\right)$ for structural policy rules of year $i$, tax-benefit parameters of year $j$ and nominal incomes of year $k$. In addition, one can consider the possibility of nominally adjusting monetary tax-benefit parameters $p$ (or, equivalently, nominal incomes $y$ ) by an uprating factor $\alpha$ (e.g., to index benefit amounts and tax threshold to price levels). In this way, the counterfactual situation $d_{t+1}\left(p_{t+1}, \alpha_{t+1} y_{t}\right)$ represents after-tax incomes obtained by applying tax rules and parameters of year $t+1$ on year $t$ household data with incomes nominally adjusted to year $t+1$. If $I$ is the inequality index of interest, then the change between initial and final period is $\Delta I=I\left[d_{t+1}\left(p_{t+1}, y_{t+1}\right)\right]-I\left[d_{t}\left(p_{t}, y_{t}\right)\right]$. Following Bargain and Callan (2010) and Bargain et al. (2011), this change can be decomposed into contributions of changing policy ("direct policy effect") and changing populations ("other effect", i.e., the underlying distribution of pre-tax-benefit incomes):

$$
\begin{aligned}
& \Delta I=\quad \mathrm{I}\left[d_{t+1}\left(p_{t+1}, y_{t+1}\right)\right]-\mathrm{I}\left[d_{t}\left(\alpha_{t+1} p_{t}, y_{t+1}\right)\right] \\
&+\mathrm{I}\left[d_{t}\left(\alpha_{t+1} p_{t}, y_{t+1}\right)\right]-\mathrm{I}\left[d_{t}\left(\alpha_{t+1} p_{t}, \alpha_{t+1} y_{t}\right)\right]
\end{aligned}
$$

(direct policy effect)

(other effect)

33. For more recent years, the OECD tax-benefit models are available for all OECD countries where significant out-of-work benefits are in place, as well as for an increasing number of non-OECD countries. They are regularly updated to account for relevant policy changes each year. However, models for 1995 are not available for all countries, and no models exist for years prior to 1995. The models, as well as an on-line tax-benefit calculator, are available on www.oecd.org/els/social/workincentives. 
To illustrate this approach, the OECD Secretariat has commissioned a study for the United States, one of only a few countries where available household microdata and microsimulation models cover the period studied in this paper. Benefits are, however, not simulated in the underlying model (NBER's TAXSIM) and the study is therefore limited to the tax side only. Full results are reported in Bargain et al. (2011).

The figure below shows that pre-tax inequality (which includes most benefits) has risen substantially. Among working-age households, the inequality of pre-tax incomes (which include unemployment insurance and other government transfers) has grown substantially. The rise was particularly notable between 1978 and 1992 . Between 1978 and 2007, the P90/P10 measure (not reported) went up by some 40\%, with widening income gaps below and above the median each contributing about one half of the total change. Figure A shows that the Gini coefficient, which places much more weight on the middle of the distribution has increased by some 8 points over the period as a whole (an increase of 24\%). In line with the results reported earlier in Figure 9c, a comparison between pre- and after-tax distributions shows a small increase in redistribution through the tax system, meaning that the tax system has slightly slowed the growth in after-tax inequality. ${ }^{1}$

However, the decomposition reveals that most of the increase in redistribution did not result directly from tax policy reforms but was a consequence of the changing distribution of pre-tax incomes. Indeed, the direct effects of policy changes more or less cancelled out over the period as a whole, with a slight increase or decrease depending on the inequality measure used. Based on the Gini measure, the direct effect of all reforms taken together appeared slightly disequalising.

While the cumulative effect of reforms is small, there are some significant policy effects for individual sub-periods. Interestingly, their patterns appear to be roughly in line with popular perceptions regarding the political cycle, with disequalising (equalising) effects observed for policy changes implemented during Republican (Democrat) administrations. There were significant differences between results for the lower and upper parts of the distribution. Policy reforms enacted in the early and mid 1990s reduced income gaps at the bottom to below their 1978 value (as measured by the p50/p10 ratio, not reported here). But no equalising effects of policies could be discerned for the upper part of the distribution (p90/p50 ratio). For the period as a whole, tax policy changes appear to have slightly exacerbated trends towards widening income gaps at the top.

These results are relative to a 1978 tax system that was fully inflation-adjusted (i.e., $\alpha$ corresponds to the consumer-price index). The interpretation is that the tax system in the mid-2000s would have been somewhat more redistributive if policy makers had implemented no reform at all and had, instead, simply adjusted all monetary tax parameters in line with inflation. This is a conservative yardstick as average incomes have grown more quickly than prices over the period. The direct policy effects of reform would therefore show up as more disequalising if they had been measured against an earnings or income-adjusted counterfactual.

\section{Inequality before and after tax in the United States: Total redistribution and direct policy effect}

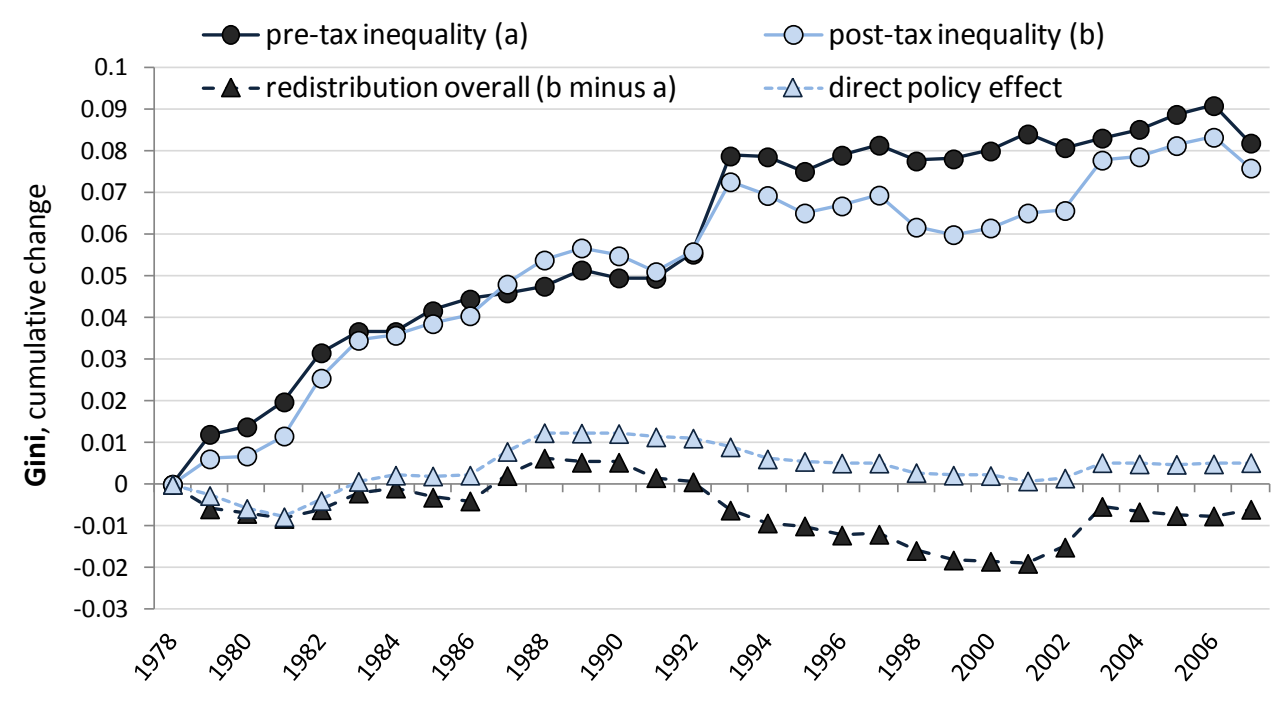

Note: Households with at least one working-age adult (15-64). Incomes are equivalised using the square-root scale.

Source: Bargain, O., M. Dolls, H. Immervoll, D. Neumann, A. Peichl, N. Pestel, S. Siegloch (2011), "Tax Policy and Income Inequality in the United States, 1978-2007: A Decomposition Approach", paper to be presented at the National Tax Association conference.

1. The inequality cushioning effect of the tax system alone was, however, much less effective in the upper half of the 
distribution (where redistribution offset about one fifth of the increase in the pre-tax P90/P50 ratio) than below the median (where roughly one half of the increase in P50/P10 was offset). This indicates limitations of progressive policies at moderating growing inequalities at the top of the distribution, as well as the success of the Earned Income Tax Credit (EITC) in strengthening redistribution at the bottom.

77. For each family, changes in tax burdens and benefit entitlements do not only result from policy action; they can also occur if policies are not adjusted. Since income taxes depend on income levels, higher or lower earnings will alter the share of gross earnings that taxpayers are liable to pay in taxes. The same is true for income-tested or earnings-related benefits. In a progressive tax-benefit system, rising nominal earnings levels result in lower net benefits (benefits minus taxes) unless all relevant policy parameters (such as tax-band limits, benefit amounts, income limits) are adjusted for income growth. When average earnings levels go up in most years, this leads to "automatic" changes in redistribution mechanisms, if no policy action is taken (OECD, 2008b). In the context of income taxes, the mechanism of automatically increasing revenues is often referred to as "fiscal drag". For simplicity, this term will be used below to refer to changes in either tax or benefit amounts that result from changing earnings levels in the economy if tax-benefit systems are kept nominally "frozen" (i.e., if tax-band limits, benefit amounts, etc. are not adjusted). In discussing changes in tax burdens and benefit entitlements, this section then distinguishes between the effects of legislative policy initiatives on one hand, and the impact of changing earning levels (fiscal-drag) on the other. The sum of these two components yields the total "actual" change (for a formal decomposition, see OECD, 2008b).

78. The reasons for distinguishing between policy and fiscal-drag effects are two-fold. First, if average nominal earnings grow quickly (whether due to inflation or real earnings growth) the effect on total government revenue and expenditure can be substantial and this tax revenue has implications for redistribution policy. ${ }^{34}$ For instance, one interesting question is whether policy changes have tended to offset the fiscal drag and, similarly, to what extent governments rely on the fiscal-drag effect as a way of increasing revenues, or reducing benefit expenditure.

79. Second, and most relevant in the context of this paper, fiscal-drag effects are likely to have important distributional implications. Like legislative policy reforms, an erosion of benefit levels or tax thresholds relative to income levels will affect some families more than others. For instance, a failure to adjust benefit levels as earnings increase can cause low-income families, who rely on government benefits for much of their income, to drop further down in the income distribution.

80. The analysis that follows uses a graphical format to summarise income changes resulting from fiscal drag and discrete policy changes. Figure 13 displays changes in net transfers (benefits minus taxes) between 1995 and 2005 as a percentage of household disposable income. A policy change that increases, or decreases, everyone's disposable income by the same proportion has no impact on the income distribution. In the figure this would show up as a horizontal line. Downwards (upwards) sloping lines are indicative of progressive (regressive) changes and would tend to cause a narrowing (widening) of the income distribution, at least within the segment of the population represented in the particular graph. ${ }^{35}$ All calculations below relate to families who do not receive unemployment benefits that depend on a previous

34. Calculations in Immervoll (2005) indicate that, at moderate rates of nominal earnings growth, the additional revenue generated by fiscal drag over a four-year period can sum to about third of total annual receipts if the income-tax schedule is fairly progressive.

35. Very highly "progressive" changes that change the ranking of families can also increase inequality. For instance, if family A with initial income of 95 benefits from an additional transfer of 15, while family B with initial income of 100 receives no increase, then the income gap between the two is doubled. 
employment history. Instead, and subject to relevant income limits, they may be entitled to means-tested assistance benefits.

\subsubsection{Single individuals}

81. Figure 13a shows that, in the absence of either automatic or discretionary policy adjustments, fiscal-drag effects would have caused net transfers to fall significantly in almost all countries (shaded areas representing the fiscal-drag effect due to inflation and real earnings growth, respectively). The exception is Japan, where price deflation over much of the 1990s and early 2000s caused nominal wages to remain close to their 1995 levels. The potential income loss resulting from fiscal drag is often particularly pronounced at lower earnings levels. The main factors driving this pattern are benefits and tax reliefs targeted to low-income tax payers, which can quickly fall in value when a family's nominal earnings go up and which generally stop entirely once earnings reach a certain threshold.

82. For instance, average earnings in Australia went up by about 55\% in nominal terms between 1995 and 2005. Without any adjustments, the value of means-tested benefit entitlements relative to actual 2005 income would be about a third lower than with full wage indexing. Legislative policy changes (light line in Figure 13) compensated about half of this, so compared with full wage-indexing, low-income Australian singles have lost around 15\%. In other words, their income would be 15\% higher had the 1995 policy stayed in place, and been adjusted in line with wage growth every year (this is in line with the drop in the maximum UA benefit entitlement shown in Annex Table A5). At the top, legislative policy reforms have more than compensated for fiscal-drag: Tax burdens for high-income earners have dropped significantly, pushing up their net incomes by $2-3$ percent. The "break-even" point is between the $6^{\text {th }}$ and $7^{\text {th }}$ earnings decile (indicated by the vertical dashed lines). At this earnings level the sum of benefits and taxes is unchanged relative to the 1995 system. That is, at this earnings level, net incomes in 2005 are the same as they would have been had the 1995 system remained in place and all policy parameters had been adjusted for wage growth over this period.

83. With the exception of Austria, legislative policy changes in all of the countries shown resulted in higher net incomes in the top half of the earnings distribution. These changes were partly offset by the fiscal-drag effect, but net gains remained in Australia, Finland, Germany and the United Kingdom. For single low-income earners, policies mostly reduced tax burdens or increased the generosity of benefits as well. Declining tax burdens or higher benefits in France (introduction of an in-work tax credit), Italy (introduction of a new standard tax allowance) ${ }^{36}$ and the United Kingdom (single individuals are now entitled to in-work benefits), largely compensated the fiscal-drag effect. In the majority of countries, however, the combined adjustments fell short of full wage-indexation. In these cases, someone earning a low wage at a given percentage of the AW dropped further down in the income distribution.

84. In summary, the changes in tax burdens and benefit entitlements for single individuals were mostly "regressive" over the 1995-2005 period; among the countries shown, Italy and Japan were the only ones where changes appear to have clearly strengthened redistribution. In many other countries, policy changes (combined, where they exist, with automatic adjustments such as inflation indexing) resulted in more generous benefit entitlements in nominal terms. But benefit recipients nevertheless mostly lost ground in the income distribution as minimum-income and cash housing support did not keep pace with earnings growth. ${ }^{37}$ Recipients of minimum-income benefits have often seen a considerable worsening of

36. Unlike most other OECD countries, Italy does not operate a comprehensive minimum-income benefit programme. Single individuals with no or very low earnings therefore neither receive benefits nor pay taxes. As shown in the graph, these individuals are therefore not affected by fiscal drag.

37. The results for Germany at the bottom of the earnings distribution are primarily driven by the reduction in housing supplements for recipients of social assistance/unemployment assistance recipients. German 
their income position, even relative to people on unemployment support, whose relative incomes declined as well. On the other end of the income spectrum, tax policy was largely successful at preventing fiscaldrag related tax increases: single higher-income earners frequently saw lower tax burdens in 2005 than in 1995.

\subsubsection{Families with children}

85. Patterns of income changes are more complex for families with children. This is especially the case at lower earnings levels, and for low-income lone parents for whom family benefits or child-related tax reductions are more generous (Figure 13b, earnings deciles shown for lone parents refer to womenspecific earnings distributions). As a result of the more generous tax credits and family benefits for this group, there is more scope for inflation and real earnings growth to erode the value of these support measures relative to average earnings and in real terms. It is therefore interesting to ask, whether legislative policy measures were less effective at counter-acting fiscal-drag related tax increases and benefit reductions when children are present (e.g., because adjustments for rising prices and real earnings are less frequent and/or complete in the case of child-related policy instruments). Across countries, Figure 13b provides a mixed picture. Austria (for those in work), as well as Australia, Germany, Italy, Japan and the United Kingdom appear to have been successful at preventing losses for low-income lone parents. Net transfers declined, however in the Czech Republic (where across-the-board cuts in family benefits affected families at all earnings levels), as well as in Finland (where real-term reductions in family benefits and the Lone Parent Supplement combined with faster withdrawal of housing benefits had a strong impact on low-income lone parents) and the United States/Michigan (where benefit entitlements for lowincome lone parents declined strongly in real terms). Net transfers also declined in France for most working lone parents (a somewhat more generous housing benefit was withdrawn more rapidly while the introduction of the prime pour l'emploi and reductions in income-tax rates were often not enough to offset the new or increased social-security taxes CRDS and CSG).

86. A similar pattern is shown in Figure 13c for a two-earner family (with the woman earning the median of the women-specific earnings distribution, and men's earnings as indicated on the horizontal axis). As a result of more generous family benefits/assistance, there are gains for German and (some) Australian two-earner families. Reductions in taxation and social security contributions in Finland and Italy (where family benefits were also made more generous for some) produced gains for most two-earner families. Policy changes in the United Kingdom, Austria and France mostly compensated for inflation and earnings growth, while families in the United States lost at the very bottom, and gained at moderate and higher earnings levels.

87. In summary, tax and benefit changes between 1995 and 2005 appeared less "regressive" (or more "progressive") for families with children than for single and childless people. In general, earnings growth and inflation have a much greater influence on the workings of the redistribution system when children are present. But although sizable fiscal-drag effects mean that low-income families can face big losses if governments "do nothing" to adjust benefit rules, a few countries (e.g., Australia, United Kingdom) were remarkably successful at protecting low-income families with children from losing ground relative to higher-income groups. Where legislative policy changes were less pro-poor (e.g., Finland, United States), the erosion of benefits due to inflation and real earnings growth did, however, result in sizable losses at the bottom.

housing benefit rules are different for recipients of assistance benefits (housing supplement) and for other housing-benefit claimants (standard housing benefit). Information on the limits that authorities use in assessing reasonable housing costs for the purpose of calculating housing supplements is not available for 1995. The results are based on the simplifying assumption that these ceilings are the same proportion of standard housing benefits in 2005 and in 1995. 


\subsubsection{Consequences of policy reforms for people's position in the income distribution}

88. By combining the calculated net incomes in 1995 and 2005 with household income data, it is possible to indicate whether particular families experienced gains or losses and what these income changes meant for their position in the overall income distribution. Figure 14 shows how much a family had to earn under 2005 and 1995 policies in order to reach different decile groups of the income distribution.

89. The spread of income distributions, and the position of the various families in them, differ markedly between countries. Hence, depending on the country, a given income change can have very different implications for one's position relative to the rest of the population. In the Czech Republic and the United States, full-time earnings around the $10^{\text {th }}$ percentile put a single-person household in the second decile group of the household income distribution, while in Australia, Finland, Italy, Japan and the United Kingdom, full-time work at the same point in the earnings distribution secures a place above the lowest third of the overall income distribution. At the other end of the earnings spectrum, a single paid at the $80^{\text {th }}$ earnings percentile is among the richest (in terms of net income) 20 percent of households in Australia, Austria, Germany, Japan and the United Kingdom. In the United States, however, someone with earnings among the highest 20 percent of full-time earners, and no other incomes, only makes it into the top 40 percent $\left(7^{\text {th }}\right.$ decile group) of the household income distribution.

90. The effects of policy changes can be seen from the difference between the solid and dashed lines and mirror those shown earlier in Figure 14. A net gain is indicated by a solid line that is above (to the left of) the dashed line. This means that the earnings needed to achieve a given position in the income distribution under 2005 tax-benefit rules are lower than they would have been under the (wage-indexed) 1995 system. For instance, for the United States, Figure 14a shows that single individuals earning around 30 percent of the average wage (roughly the level of the federal minimum wage in 2005) would have had to work almost $1 / 3$ longer (or earn 1/3 more per hour) in order to make up for the additional net tax burdens (or the lost net benefit). The additional earnings needed to compensate for lower net benefits at the bottom are even larger in Australia, both because benefit reductions are sizable (see Figure 13a) and because relatively high benefit withdrawal rates mean that the payoff from earning more is limited.

91. On the other hand, there are several examples of net gains for families with children. The most sizable gains are shown for lone-parent and two-parent families in Australia, Italy and Germany. More generous benefits in Germany lift many two-parent families, and some lone-parents, almost a full decile further up in the income distribution, although gains were smaller for (the large number of) low-paid lone parents.

\section{SUMMARY AND CONCLUSIONS}

92. Despite rising employment rates between the mid-1980s and mid-2000s, a large majority of OECD countries have seen substantial and sustained increases in market-income inequality among working-age households. In most countries, inequality among "non-elderly" household have widened during most phases of the economic cycle and any episodes of narrowing income differentials have usually not lasted long enough to close the gap between high and low incomes that had opened up previously. Across countries with data covering different points in the past two decades, the Gini coefficient for market income has, on average, increased by $16 \%$ every ten years. This is a very substantial increase over a relatively short period of time. It is, for instance, in the same order of magnitude as the reduction in 
inequality among the non-elderly that is achieved by the entire tax-benefit system in some countries. In most cases, market-income inequality has risen more strongly during the first half of the two decades. In addition, most of the countries with data going back further have seen large increases in market-income Ginis before the mid-80s. The upwards trend in market-income inequality continued after the mid-90s, but at a much slower pace.

\section{Compared with the mid-1990s, tax-benefit systems are now less effective at reducing inequality}

93. With progressive redistribution systems in place, greater inequality automatically leads to more redistribution, even if no policy action is taken. For instance, when unemployment goes up, measured redistribution is likely to increase because more people claim unemployment benefits. Similarly, a progressive income tax redistributes more when taxable incomes become more dispersed (and very little if everybody earns about the same). In the context of rising market-income inequality, tax-benefit systems have indeed become more redistributive over the past 20-25 years. This did not stop income inequality from rising (in terms of the Gini, market-income inequality grew by roughly twice as much as redistribution). By redistributing more, tax-benefit systems in several countries were able to offset more than half of the rise in market-income inequality up until the mid-90s (e.g., Australia, Canada, Finland and Sweden). But in most countries, redistribution systems have no longer been able to counteract increasing market-income inequality since then. In the United States, Israel and the United Kingdom, taxes and benefits compensated only a relatively small part (one fifth or less) of the increase in market-income inequality over the period as a whole.

94. For countries with long-term income distribution data, growing market-income disparities were the main driver of inequality trends between the mid-80s and mid-90s. In the 10 years that followed, reduced redistribution was sometimes the main source of widening household-income gaps. Indeed, despite a slowing of the trend towards greater market-income disparities, income inequality after adding benefits and taxes has increased at faster rate since the mid-90s than it had in the decade before.

\section{These changes in overall redistribution were mainly driven by the benefit system...}

95. Benefits have a much stronger impact on inequality than social contributions or taxes, despite the bigger aggregate size of direct taxes and, hence, their bigger average impact on household incomes. In general, changes on the benefit side can therefore be expected to be a more significant driver of the extent of overall redistribution and inequality.

96. On average across 29 OECD countries, cash support for working-age individuals and their families has grown in real terms but has accounted for a declining share of total social spending (the share fell from $27 \%$ in 1985 to $25 \%$ in 1995 and $21 \%$ in 2005). Since the 1980 s, benefits have become more important for reducing inequalities. But in half of the countries, they have become less redistributive since the mid-1990s. In countries with big increases in the redistributive effect of benefits, the trend was mainly driven by growing average benefit amounts (Finland, Germany, Norway, Switzerland). The degree of benefit targeting ("progressivity") has changed less. The relatively small change in benefit progressivity over a 20-year period, and its limited impact on the redistribution properties of cash transfers highlights the importance of spending levels for inequality outcomes in the past, and the potential difficulties of safeguarding effective redistribution policies in a context of declining social budgets. However, it also suggests considerable scope for strengthening existing targeting mechanisms (e.g., by preventing lowincome jobseekers from going without support).

97. The number of people receiving benefits has a quantitatively sizable impact on measured redistribution. Across countries, there has been no uniform trend of the numbers of unemployment benefit claims. They rose strongly in Belgium, Germany and Portugal over the 1985-2005 period, and fell in Italy, 
the United Kingdom and (since the mid-1990s) in most Nordic countries, Spain and United States. In part, the number of recipients is simply a reflection of the number of people facing particular types of risks that the benefit is designed to address. But in addition, the shares of unemployed reporting benefit receipt have dropped in a majority (two thirds) of countries. Changing eligibility rules, including the enforcement of job-search conditions and other behavioural requirements, play a role (and can contribute to a shift of benefit caseloads from unemployment support to incapacity benefits and other "inactive" transfers, such as incapacity benefits). The significant increase in the proportion of non-standard workers, who are typically much less likely to qualify for benefits, has also contributed to lower benefit coverage rates in some countries. Transfer policies have their role in addressing problems of incomplete benefit coverage among this group, but non-standard work and dual labour markets present issues for labour-market policy more broadly.

98. Those who are entitled to unemployment benefits have seen benefit generosity drop since the mid-1990s. Calculations using OECD tax-benefit models show that net replacement rates of unemployment support declined in seven out of ten countries since 1995. Large falls were recorded in countries where the generosity of more than one element of the overall support package was reduced (for instance in Finland, Germany, and the Czech Republic).

\section{... while tax reforms have contributed little to inequality reduction}

99. Despite a flattening of rate structures, personal income taxes have become somewhat more progressive in about half of the countries. This is consistent with the strong trend towards greater marketincome inequalities, which, in itself, magnifies tax-burden differences between high-income and lowincome taxpayers. Reforms that have broadened the tax base are also likely to have moderated tax-burden reductions for higher-income groups that result from flatter tariffs. On aggregate, income taxes have declined as a share of overall revenues. Effective tax rates faced by all "non-elderly" households are now lower in most OECD countries now than they were 20-25 years ago. Those two trends (greater progressivity, less revenue) have had opposite effects on the redistributive capacity of income taxes. They have therefore partly cancelled out and produced relatively small changes in overall redistribution.

100. Tax-benefit policy reforms played a significant role in the weakening equalising effect of redistribution policies since the mid-1990s. Changes in tax burdens and benefit entitlements were mostly "regressive" for single individuals and childless families in particular. In a number of countries, policy changes (combined, where they exist, with automatic adjustments such as inflation indexing) resulted in more generous benefit entitlements in nominal terms. But benefit recipients nevertheless mostly lost ground in the income distribution as transfers to the lowest income groups (minimum-income and cash housing support) did not keep pace with earnings growth. On the other end of the income spectrum, tax policy resulted in gains or in comparatively smaller losses. Changes for families with children appeared less "regressive" (or more "progressive"). The erosion of benefits due to inflation and real earnings growth did, however, result in sizable losses at the bottom. A few countries (e.g., Australia, United Kingdom) appeared successful at protecting low-income families with children from losing ground relative to higherincome groups.

\section{What lessons for future redistribution policies?}

101. Historical income patterns are informative for designing policies today, when most OECD countries are emerging from a deep recession with their public finances under severe strain. Large and persistent losses of low-income groups following recessions underline the importance of well-targeted income-support policies during economic slumps, as well as during the recovery. The extent of these losses show, however, that redistribution strategies based on government transfers alone would be neither 
effective nor financially sustainable. In restoring incomes at the bottom, a key challenge for policy is to facilitate and encourage employment and earnings growth that benefits low-income groups in particular.

102. The relative stability of higher incomes after recessions, as well as their longer-term trends, are important to bear in mind in policy debates that seek to define a response to growing inequalities. They are also relevant in the context of planning fiscal consolidation strategies. For instance, the historical income trends do signal a significant shift in the relative "tax capacity" from lower to higher-earning groups in the aftermath of steep downturns. It may therefore be necessary to critically review whether existing tax provisions should be adapted in light of equity considerations and current revenue requirements, in particular where those with high or very high incomes have benefited from declining overall tax burdens in the past (e.g., because of non-compliance, because tax expenditures mainly benefit high-income groups, or because of declining property and wealth taxes).

103. Redistribution systems were, on average, relatively effective at slowing trends towards widening income gaps when these trends were largely due to falling incomes at the bottom (as was the case in many countries between the mid-80s and the mid-90s). Tax-benefit systems were less successful at offsetting growing inequality in the upper parts of the distribution. One notable implication is that benefits (which are more important for low-income groups) were more responsive to growing inequalities than were taxes (which account for a greater part of incomes in the middle and at the top of the distribution). With unchanged policies, redistribution systems can be expected to remain less effective at cushioning growing income disparities at higher income levels, which have become a more powerful driver of inequality trends in some countries. 
Figure 13. Gains and losses 1995-2005: policy changes and fiscal-drag ${ }^{1}$

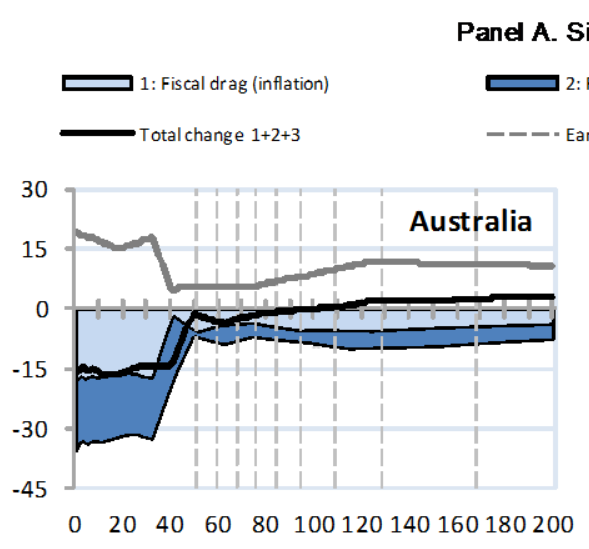

ingle-persons $^{2}$
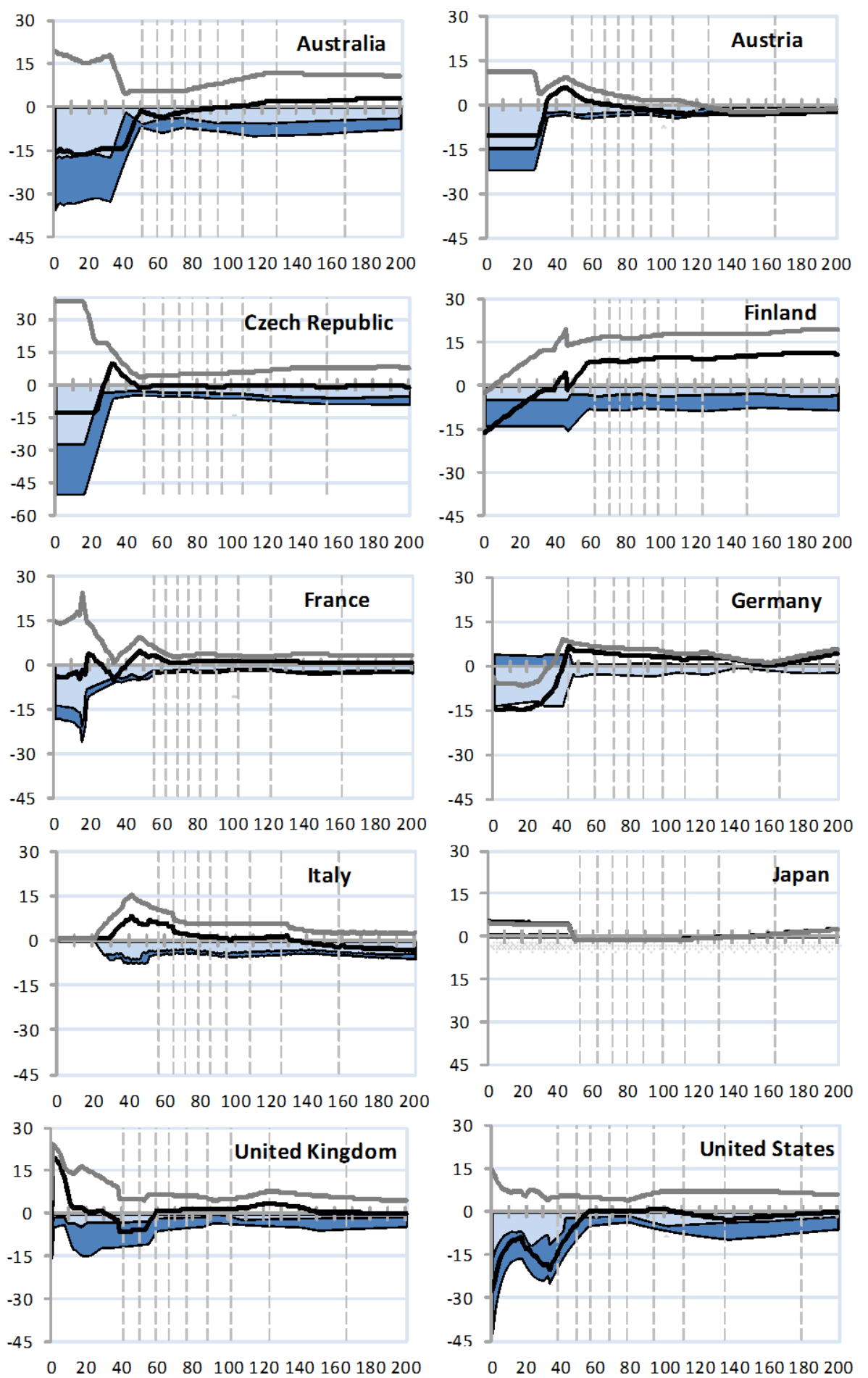

Full-time earnings (\% AW) 
Figure 13. (continued) ${ }^{1}$

Panel B. Lone parents (two children) ${ }^{3}$

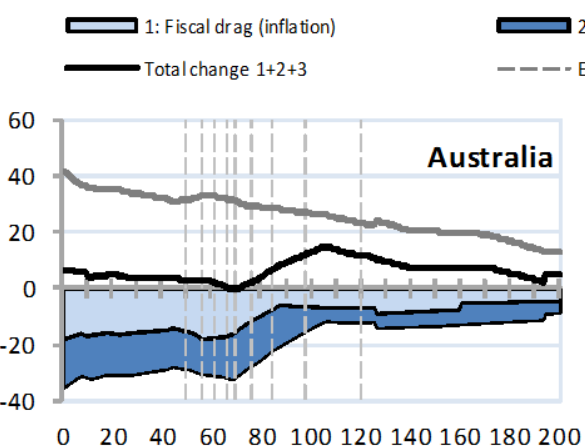

2: Fiscal drag (real wage growth) $\quad 3$ : Legislative policy

- - - Earnings Deciles

$\begin{array}{llllll}20 & 40 & 60 & 80 & 100120140160180200\end{array}$
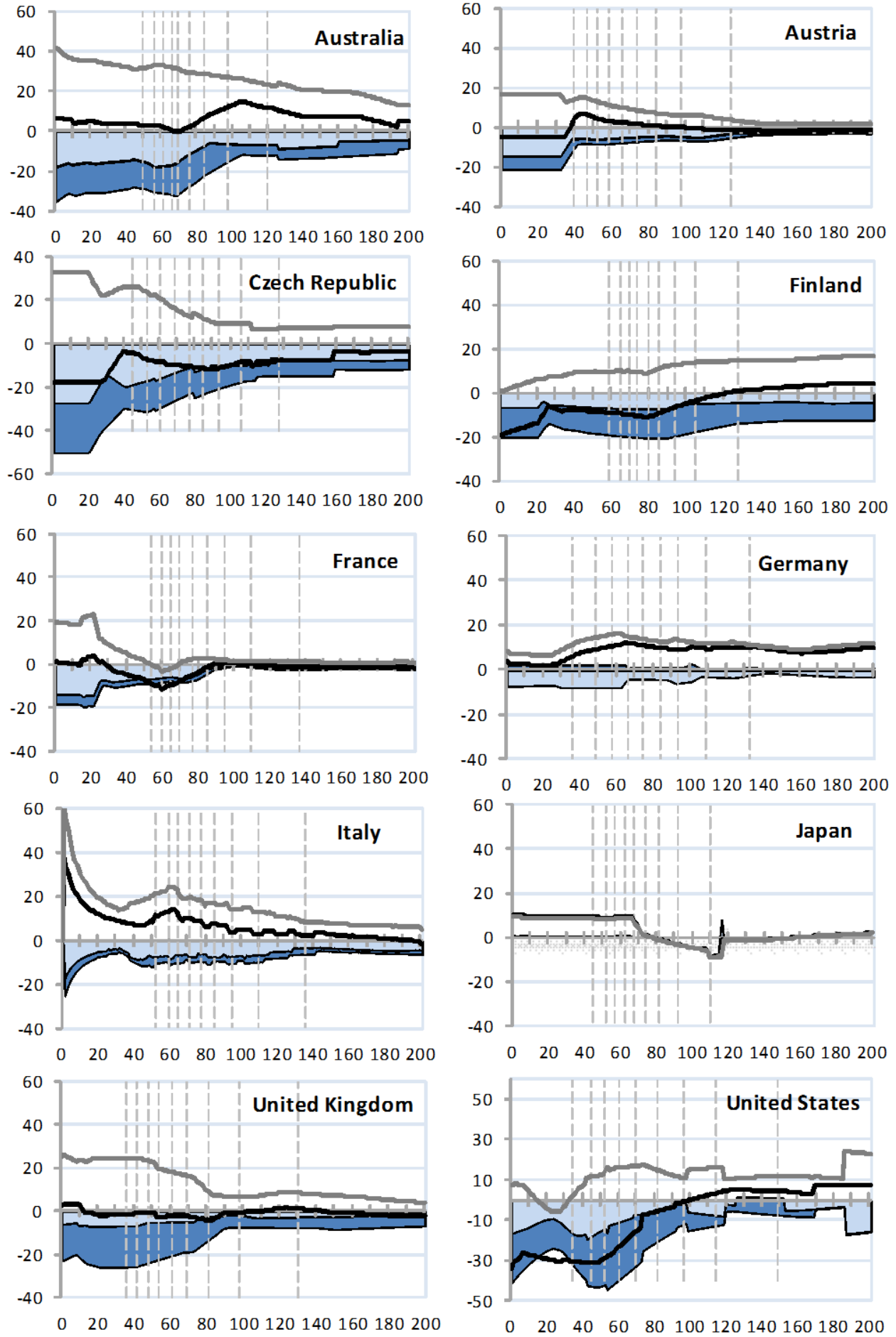

Full-time earnings (\% AW) 
Figure 13. (continued) ${ }^{1}$

Panel C. Two-eamer couple (two children) ${ }^{4}$

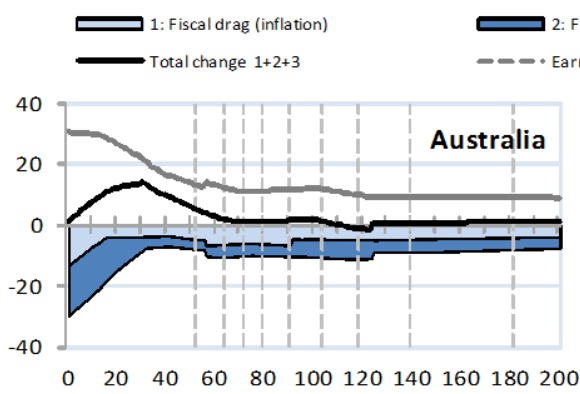

Fiscal drag (real wage growth) $\quad 3$ : Legislative policy

- - Earnings Deciles
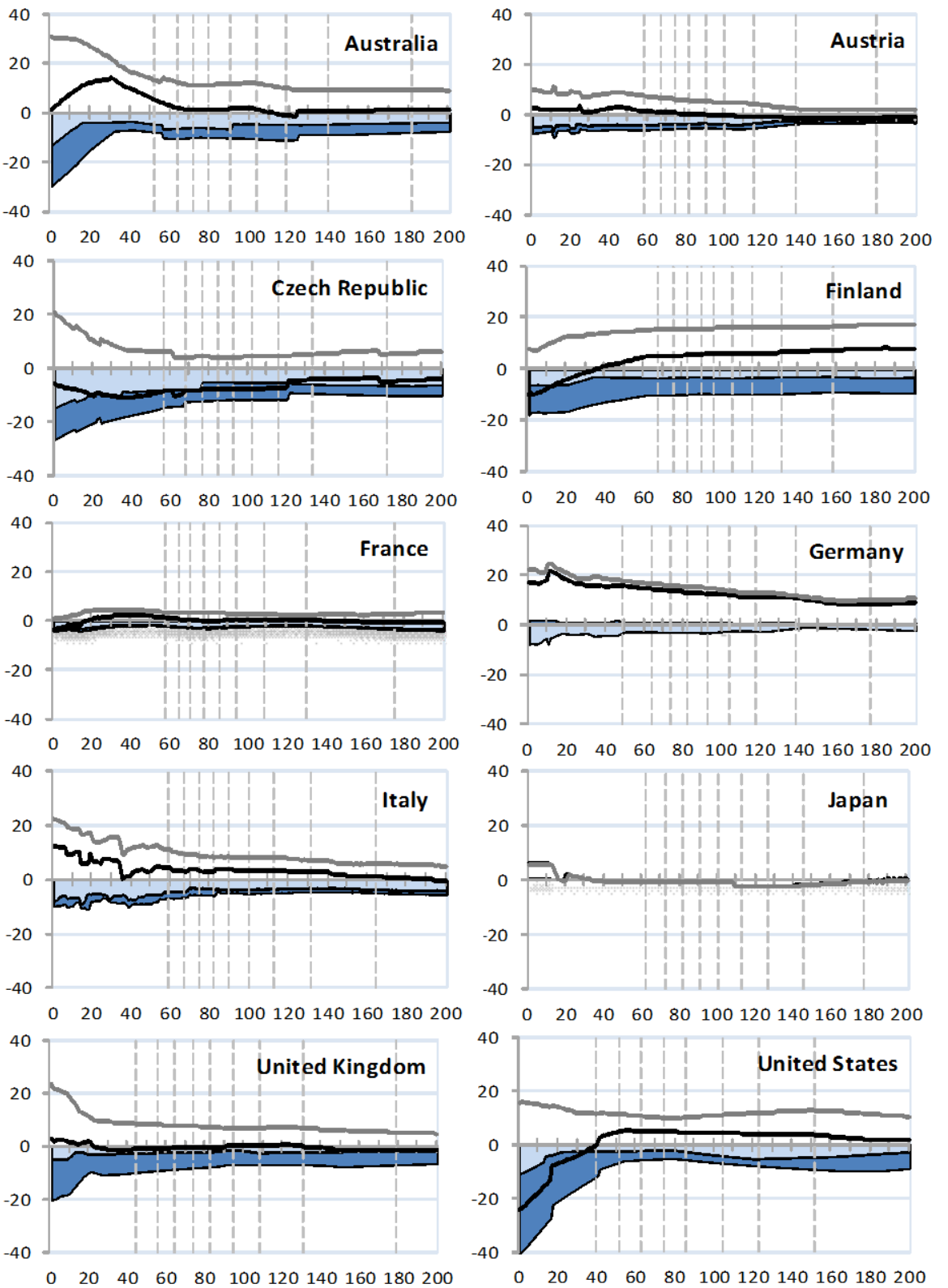

Full-time earnings (\% AW)

1. Income changes are measured relative to the income the household would have had if the 2005 tax-benefit system was a fully wage-indexed version of the 1995 system. Families are assumed not to receive unemployment benefits that depend on previous employment histories. Instead, and subject to relevant income limits, they may be entitled to means-tested assistance benefits.

2. Earnings deciles relate to the entire earnings distribution (men and women).

3. Earnings deciles relate to the earnings distribution of women only.

4. Earnings deciles relate to the earnings distribution of men only. The woman's earnings are held fixed at the median of the earnings distribution of women only.

Source: OECD tax-benefit models. 
Figure 14. Position in the income distribution under different policy scenarios ${ }^{1}$

Panel A. Single-person households ${ }^{2}$

1995 tax-benefit system (wage growth adjusted to 2005)
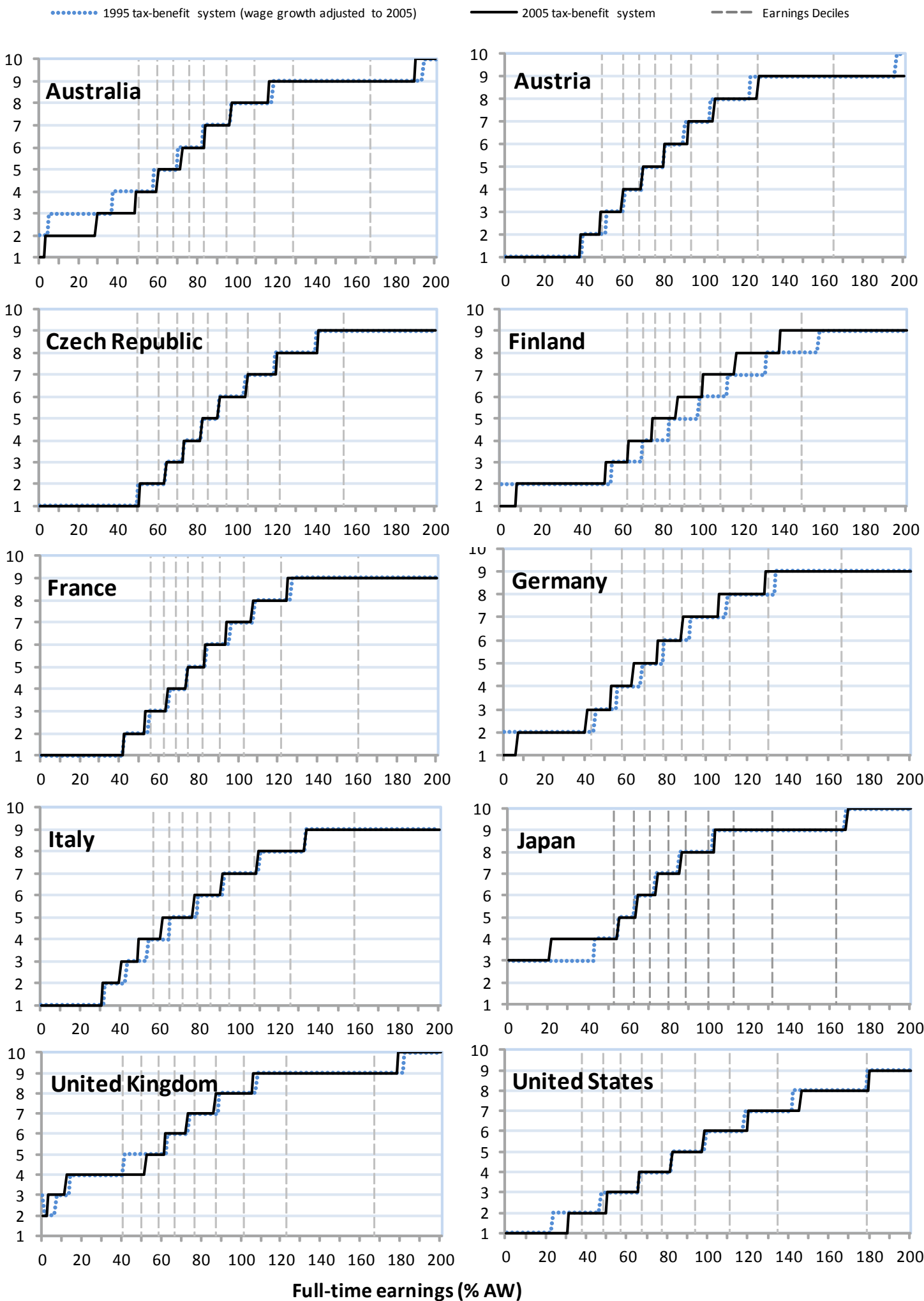
Figure 14. (continued) ${ }^{1}$

Panel B. Lone parents (two children) ${ }^{3}$

- 1995 tax-benefit system (wage growth adjusted to 2005)
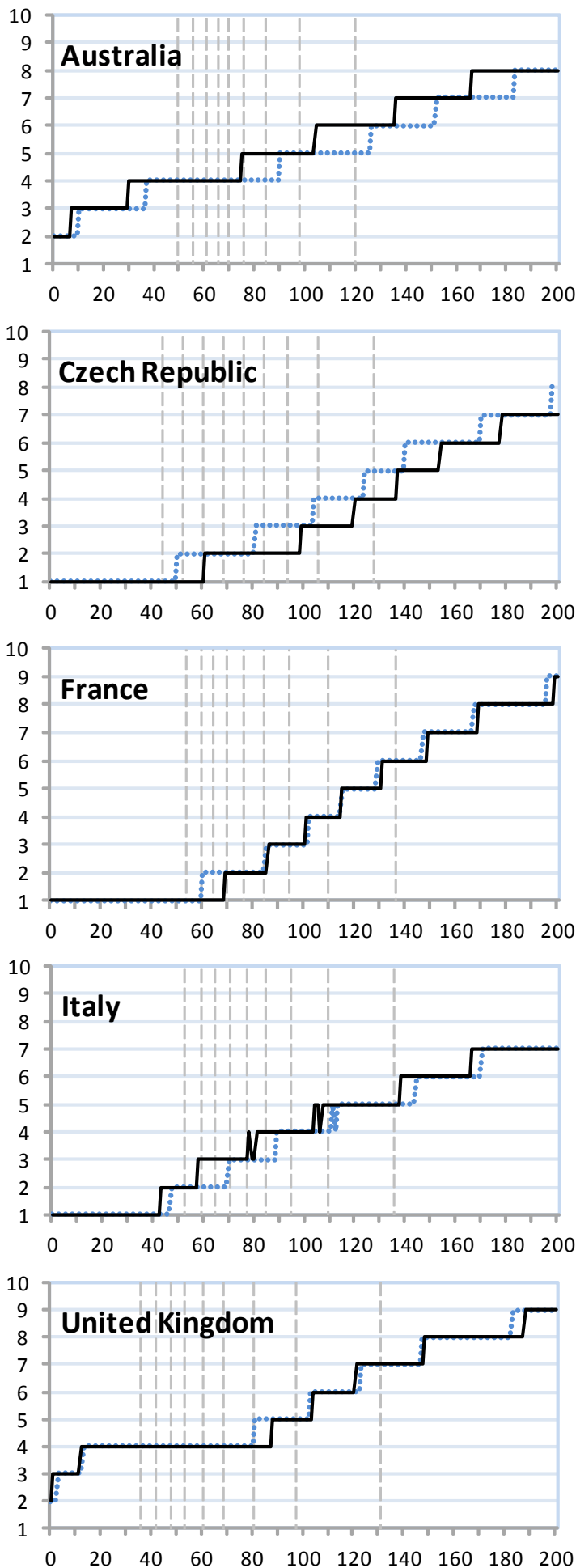
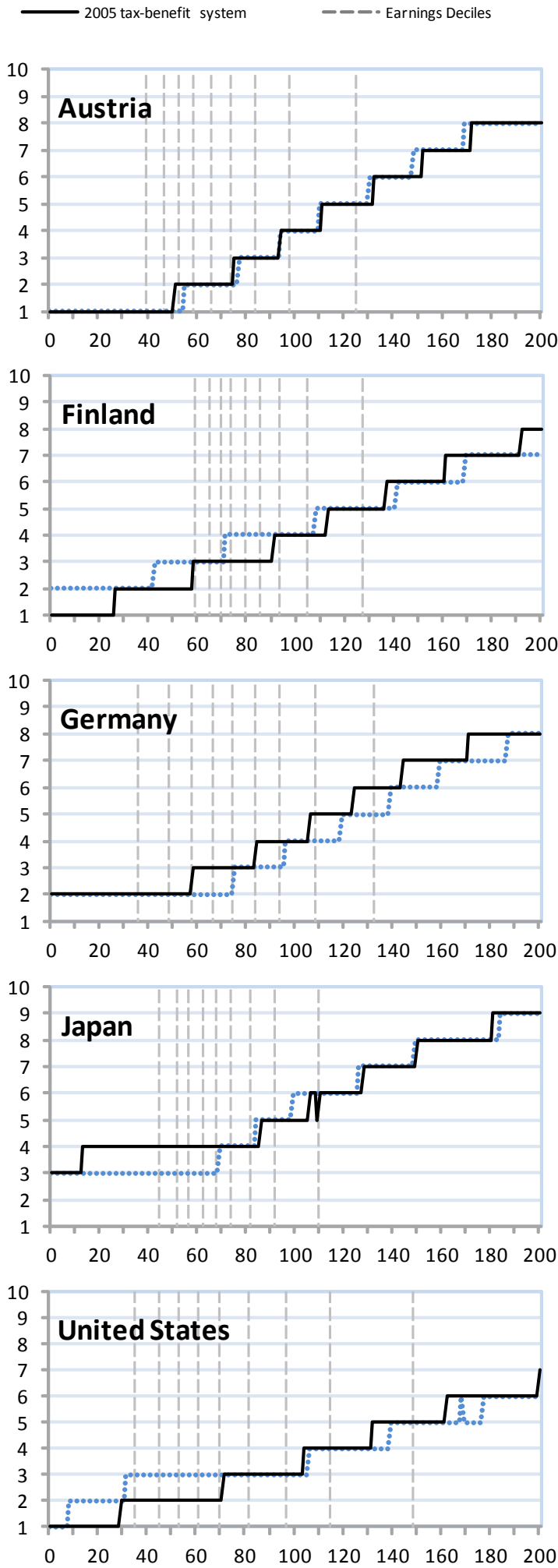

Full-time earnings (\% AW) 
Figure 14. (continued) ${ }^{1}$

Panel C. Two-earner couple (two children) ${ }^{4}$
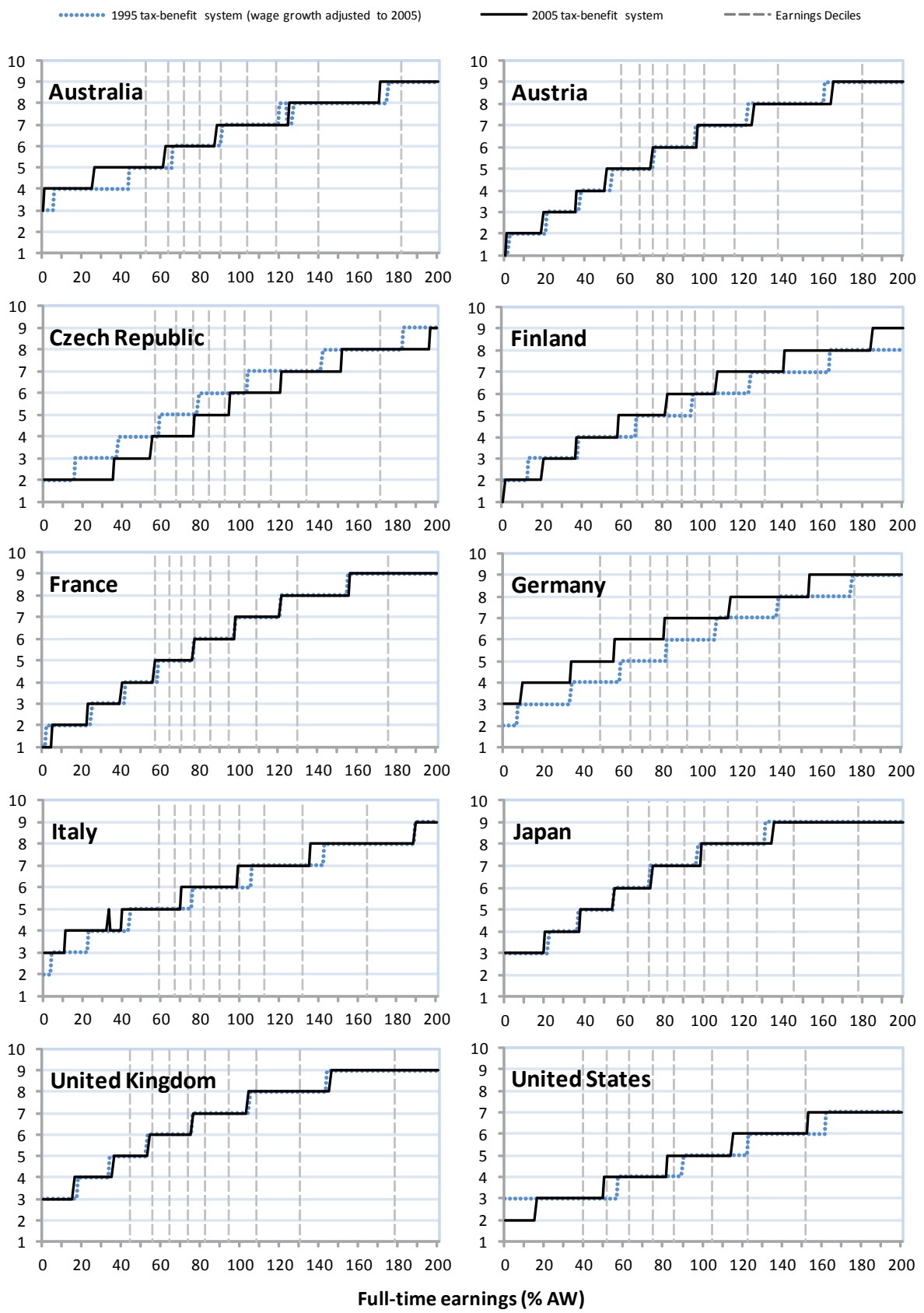

1. Deciles of household disposable income (equivalised using the square-root scale) are for the total population in the mid-2000s. The 1995 series shows where the household would be located in the income distribution if the 2005 tax-benefit system was a fully wage-indexed version of the 1995 system. Families are assumed not to receive unemployment benefits that depend on previous employment histories. Instead, and subject to relevant income limits, they may be entitled to means-tested assistance benefits.

2. Earnings deciles relate to the entire earnings distribution (men and women).

3. Earnings deciles relate to the earnings distribution of women only.

4. Earnings deciles relate to the earnings distribution of men only. The woman's earnings are held fixed at the median of the earnings distribution of women only.

Source: OECD tax-benefit models 


\section{ANNEX: ADDITIONAL DATA}

\section{Table A1. Public social expenditure: trends and components.}

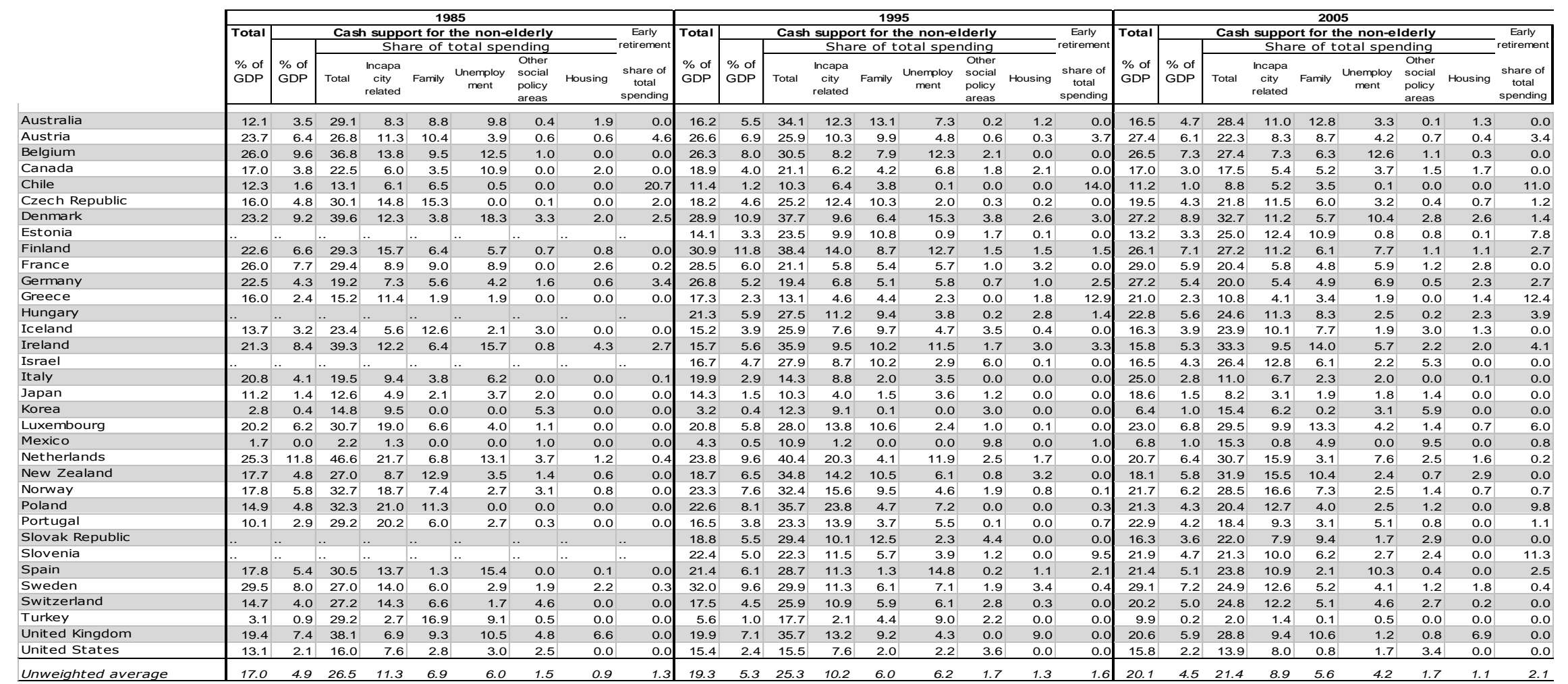

Source: OECD Social Expenditure Database (www.oecd.org/els/social/expenditure). 
Table A2. Unemployment insurance: main policy changes.

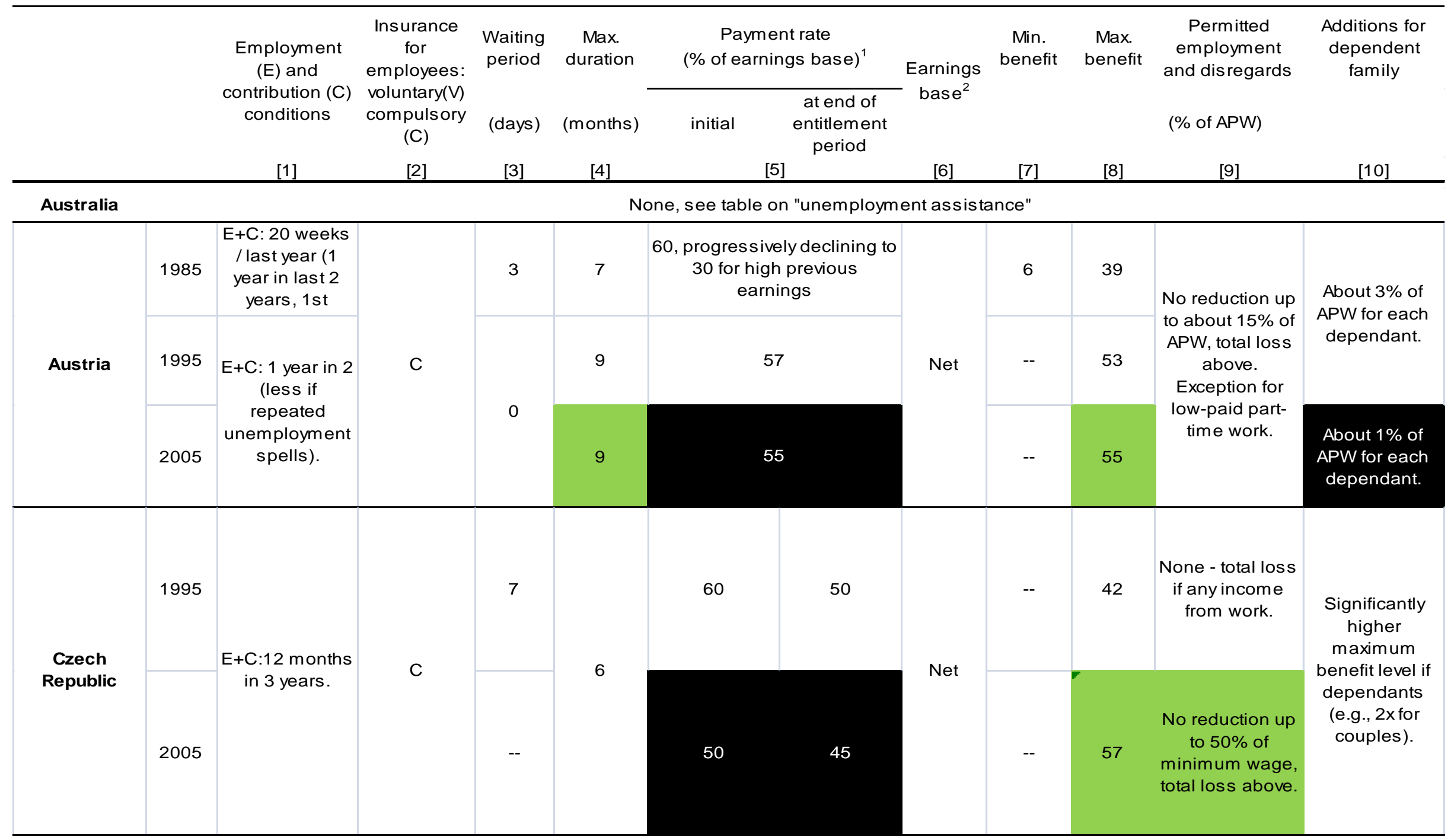


DELSA/ELSA/WD/SEM(2011)7

Table A2. Unemployment insurance: main policy changes. (continued)

\begin{tabular}{|c|c|c|c|c|c|c|c|c|c|c|c|c|}
\hline & & \multirow{2}{*}{$\begin{array}{l}\text { Employment } \\
(\text { E) and } \\
\text { contribution (C) } \\
\text { conditions }\end{array}$} & \multirow{2}{*}{$\begin{array}{l}\text { Insurance } \\
\text { for } \\
\text { employees: } \\
\text { voluntary( }(V) \\
\text { compulsory } \\
\text { (C) }\end{array}$} & \multirow{3}{*}{$\begin{array}{l}\text { Waiting } \\
\text { period } \\
\text { (days) }\end{array}$} & \multirow{3}{*}{$\begin{array}{c}\text { Max. } \\
\text { duration } \\
\text { (months) } \\
{[4]}\end{array}$} & \multicolumn{2}{|c|}{$\begin{array}{c}\text { Payment rate } \\
\text { (\% of earnings base) (1) }\end{array}$} & \multirow{2}{*}{$\begin{array}{l}\text { Earnings } \\
- \text { base(2) }\end{array}$} & \multirow{3}{*}{$\begin{array}{c}\text { Min. } \\
\text { benefit } \\
\\
{[7]}\end{array}$} & \multirow{3}{*}{$\begin{array}{c}\text { Max. } \\
\text { benefit } \\
\\
{[8]} \\
\end{array}$} & \multirow{3}{*}{$\begin{array}{c}\text { Permitted } \\
\text { employment } \\
\text { and disregards } \\
(\% \text { of APW) } \\
{[9]}\end{array}$} & \multirow{3}{*}{ 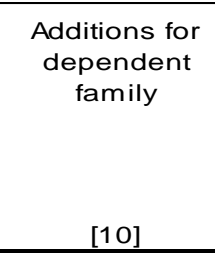 } \\
\hline & & & & & & initial & $\begin{array}{l}\text { at end of } \\
\text { entitlement } \\
\text { period }\end{array}$ & & & & & \\
\hline & & [1] & [2] & & & {$[5$} & & [6] & & & & \\
\hline \multirow{3}{*}{ Finland } & 1985 & $\begin{array}{l}\text { Earnings } \\
\text { related benefit: } \\
\mathrm{E}+\mathrm{C}: 26 \text { weeks } \\
\text { in } 12 \text { months }\end{array}$ & \multirow{3}{*}{$\begin{array}{c}\mathrm{V} \\
\text { (for earnings- } \\
\text { related part, } \\
\text { no } \\
\text { insurance } \\
\text { requirement } \\
\text { for basic } \\
\text { benefit) }\end{array}$} & 5 & $\begin{array}{l}9 \text { months } \\
\text { in one } \\
\text { calendar } \\
\text { year }\end{array}$ & \begin{tabular}{|c|} 
Basic benefit \\
(26\% of APW) \\
plus up to \\
$45 \%$ of \\
earnings \\
exceeding
\end{tabular} & $\begin{array}{l}\text { Benefit } \\
\text { reduced by } \\
20 \% \text { after } \\
100 \text { days. }\end{array}$ & \multirow{3}{*}{$\begin{array}{l}\text { Gross } \\
\text { (excl. } \\
\text { holiday } \\
\text { pay) less } \\
\text { social } \\
\text { contributi } \\
\text { ons. }\end{array}$} & 26 & \multirow{3}{*}{-- } & 0 & $\begin{array}{l}\text { Supplements: } \\
6,8,10 \% \text { of } \\
\text { APW for } 1,2,3 \\
\text { or more } \\
\text { children. }\end{array}$ \\
\hline & 1995 & $\begin{array}{l}\mathrm{E}+\mathrm{C}: 26 \text { weeks } \\
\text { in } 24 \text { months, }\end{array}$ & & \multirow[t]{2}{*}{7} & \multirow[t]{2}{*}{23} & \multicolumn{2}{|c|}{$\begin{array}{l}\text { Basic benefit ( } 23 \% \text { of APW) } \\
\text { plus up to } 42 \% \text { of earnings } \\
\text { exceeding basic benefit } \\
\text { (lower replacement rate at } \\
\text { higher earnings levels). }\end{array}$} & & 23 & & $\begin{array}{c}\text { Part-time work: } \\
\text { after earnings } \\
\text { diregard ( } 7 \% \\
\text { APW) benefit } \\
\text { reduced by } 80 \% \\
\text { of gross } \\
\text { income. Benefit } \\
+ \text { income }<= \\
90 \% \text { of } \\
\text { reference } \\
\text { earnings. }\end{array}$ & $\begin{array}{l}\text { Supplements: } \\
5,7,9 \% \text { of APW } \\
\text { for } 1,2 \text { and } 3 \text { or } \\
\text { more children } \\
\text { respectively. }\end{array}$ \\
\hline & 2005 & $\begin{array}{l}\text { E: } 43 \text { weeks in } \\
28 \text { months, } \\
\text { C: } 10 \text { months } \\
\text { (for earnings- } \\
\text { related part). }\end{array}$ & & & & \multicolumn{2}{|c|}{$\begin{array}{l}\text { Basic benefit ( } 20 \% \text { of APW) } \\
\text { plus up to } 45 \% \text { of earnings } \\
\text { exceeding basic benefit } \\
\text { (lower replacement rate at } \\
\text { higher earnings levels). }\end{array}$} & & 20 & & $\begin{array}{c}\text { Part-time work: } \\
\text { benefit reduced } \\
\text { by } 50 \% \text { of gross } \\
\text { income. Benefit } \\
\text { plus income <= } \\
90 \% \text { of } \\
\text { reference }\end{array}$ & $\begin{array}{l}\text { Supplements: } \\
4,5,7 \% \text { of } A P W \\
\text { for } 1,2 \text { and } 3 \text { or } \\
\text { more children } \\
\text { respectively. }\end{array}$ \\
\hline \multirow{3}{*}{ France } & 1985 & $\begin{array}{l}\text { E+C: } 3 \text { months } \\
\text { in last } 12 \text {. For } \\
\text { maximum } \\
\text { coverage: } 2 \\
\text { years / last } 3\end{array}$ & \multirow{3}{*}{ C } & \multirow{3}{*}{8} & $\begin{array}{l}\text { Basic } \\
\text { benefit: } \\
45 \\
\text { months. }\end{array}$ & $\begin{array}{l}\text { Basic benefit: } \\
18 \% \text { of } A P W \\
\text { plus } 42 \% \text { of } \\
\text { reference } \\
\text { earnings. }\end{array}$ & $\begin{array}{c}32 \% \text { of initial } \\
\text { benefit }\end{array}$ & \multirow{3}{*}{ Gross } & 42 & $\begin{array}{l}80 \% \text { of } \\
\text { gross } \\
\text { earnings }\end{array}$ & -- & \multirow{3}{*}{--} \\
\hline & 1995 & $\begin{array}{c}\text { C: } 4 \text { months in } \\
\text { last } 8 .\end{array}$ & & & 30 & \multirow{2}{*}{$\begin{array}{c}75, \\
\text { progressively } \\
\text { declining to } 57 \\
\text { for high } \\
\text { previous } \\
\text { earnings }\end{array}$} & $\begin{array}{c}27 \% \text { of initial } \\
\text { benefit }\end{array}$ & & 43 & 302 & \multirow{2}{*}{$\begin{array}{l}\text { employment } \\
\text { allowed (and } \\
\text { benefit reduced) } \\
\text { as long as } \\
\text { income }<70 \% \text { of } \\
\text { reference } \\
\text { earnings }\end{array}$} & \\
\hline & 2005 & $\begin{array}{c}\text { C: } 6 \text { months in } \\
22 .\end{array}$ & & & 23 & & & & 39 & 289 & & \\
\hline
\end{tabular}


Table A2. Unemployment insurance: main policy changes. (continued)

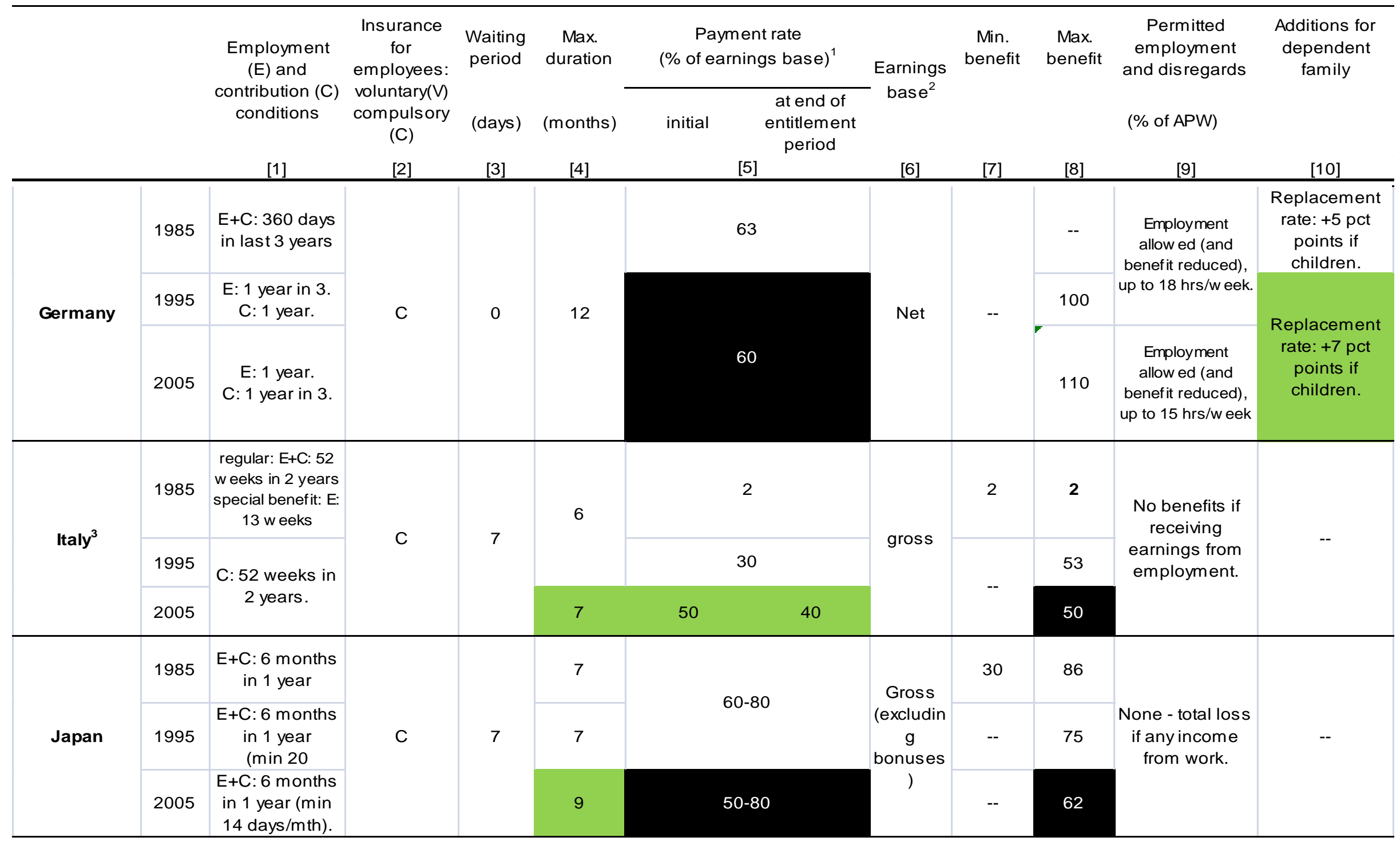


DELSA/ELSA/WD/SEM(2011)7

Table A2. Unemployment insurance: main policy changes. (continued)

\begin{tabular}{|c|c|c|c|c|c|c|c|c|c|c|c|}
\hline & & \multirow{3}{*}{$\begin{array}{l}\text { Employment } \\
(\mathrm{E}) \text { and } \\
\text { contribution }(\mathrm{C}) \\
\text { conditions }\end{array}$} & \multirow{2}{*}{$\begin{array}{l}\text { Insurance } \\
\text { for } \\
\text { employees: } \\
\text { voluntary(V) } \\
\text { compulsory } \\
\text { (C) }\end{array}$} & \multirow{2}{*}{$\begin{array}{l}\text { Waiting } \\
\text { period } \\
\text { (days) }\end{array}$} & \multirow{2}{*}{$\begin{array}{c}\text { Max. } \\
\text { duration } \\
\text { (months) }\end{array}$} & $\begin{array}{c}\text { Payment rate } \\
(\% \text { of earnings base })^{1}\end{array}$ & \multirow{2}{*}{$\begin{array}{l}\text { Earnings } \\
\text { base }^{2}\end{array}$} & \multirow{3}{*}{$\begin{array}{c}\text { Min. } \\
\text { benefit } \\
\\
{[7]} \\
\end{array}$} & \multirow{3}{*}{$\begin{array}{c}\text { Max. } \\
\text { benefit } \\
\\
{[8]} \\
\end{array}$} & \multirow{3}{*}{$\begin{array}{c}\text { Permitted } \\
\text { employment } \\
\text { and dis regards } \\
\text { (\% of APW) } \\
{[9]}\end{array}$} & \multirow{3}{*}{$\begin{array}{c}\text { Additions for } \\
\text { dependent } \\
\text { family }\end{array}$} \\
\hline & & & & & & $\begin{array}{cc}\text { initial } & \text { at end of } \\
\text { entitlement } \\
\text { period }\end{array}$ & & & & & \\
\hline & & & [2] & [3] & [4] & {$[5]$} & {$[6]$} & & & & \\
\hline \multirow{3}{*}{$\begin{array}{c}\text { United } \\
\text { Kingdom }\end{array}$} & 1985 & $\begin{array}{l}\text { C: contributions } \\
\text { on earnings of } \\
\text { at least } 25 \\
\text { times weekly } \\
\text { low earnings in }\end{array}$ & \multirow{3}{*}{ C } & \multirow{3}{*}{3} & 12 & Flat rate $(17 \%$ of $\mathrm{APW})$ & \multirow{3}{*}{--} & 17 & 17 & \multirow[t]{2}{*}{$\begin{array}{l}\text { Reduction in } \\
\text { proportion with } \\
\text { the numbers of } \\
\text { days or weeks } \\
\text { worked. }\end{array}$} & \multirow[t]{2}{*}{$\begin{array}{l}10 \% \text { of APW if } \\
\text { partner with no } \\
\text { or low } \\
\text { earnings. }\end{array}$} \\
\hline & 1995 & $\begin{array}{l}\text { C: } 12 \text { months } \\
\text { in } 2 \text { years. }\end{array}$ & & & 12 & Flat rate $(16 \%$ of $\mathrm{APW})$ & & 16 & 16 & & \\
\hline & 2005 & C: 2 years. & & & 6 & Flat rate $(14 \%$ of $\mathrm{APW})$ & & 14 & 14 & $\begin{array}{l}\text { Income above } \\
\text { limit reduces } \\
\text { benefit by } \\
\text { exceeding } \\
\text { amount. } \\
\end{array}$ & -- \\
\hline \multirow{3}{*}{$\begin{array}{l}\text { United States } \\
\text { (Michigan) }\end{array}$} & 1985 & \multirow{3}{*}{$\begin{array}{l}\text { E: } 20 \text { weeks } \\
\text { (plus min. } \\
\text { earnings } \\
\text { requirement). }\end{array}$} & \multirow{3}{*}{$\mathrm{C}$} & \multirow{3}{*}{$\begin{array}{c}0 \\
(7 \text { in } \\
\text { most } \\
\text { states })\end{array}$} & \multirow{3}{*}{$\begin{array}{c}6 \\
\text { (longer if } \\
\text { state-level } \\
\text { unemploy } \\
\text { ment } \\
\text { exceeds } \\
\text { threshold) }\end{array}$} & 46 & \multirow{3}{*}{ Gross } & 14 & 51 & \multirow{3}{*}{$\begin{array}{l}\text { Earnings < } \\
\text { gross benefit } \\
\text { are deducted at } \\
50 \% ; 100 \% \\
\text { reduction with } \\
\text { exceeding part. }\end{array}$} & \multirow{3}{*}{$\begin{array}{l}\text { around } 1 \% \text { of } \\
\text { APW for each } \\
\text { dependant. }\end{array}$} \\
\hline & 1995 & & & & & 50 & & 8 & 57 & & \\
\hline & 2005 & & & & & 53 & & 12 & 53 & & \\
\hline
\end{tabular}

1. Single worker without children, benefits may differ depending on family situation. All benefit amounts are shown on an annualised basis. "--" indicates that no information is available or not applicable. 2. Gross = gross employment income; $\mathrm{SSC}=$ (employee) social security contributions; Net = Gross minus income taxes minus SSC

3. For employees with a temporary reduction of working hours there is also the CIG scheme which pays benefits of $80 \%$ of average gross earnings for non-worked hours.

Source: OECD tax-benefit policy database (www.oecd.org/els/social/workincentives). 
Table A3. Unemployment assistance: main policy changes ${ }^{1}$

\begin{tabular}{|c|c|c|c|c|c|c|c|c|c|c|}
\hline & & \multirow{2}{*}{$\begin{array}{c}\text { Employment } \\
\text { record in } \\
\text { months }^{2} \\
{[1]}\end{array}$} & \multirow{2}{*}{$\begin{array}{c}\text { Waiting } \\
\text { period } \\
\text { (days) } \\
\text { [2] }\end{array}$} & \multirow{2}{*}{$\begin{array}{c}\text { Duration } \\
\text { (months) } \\
{[3]} \\
\end{array}$} & \multirow{2}{*}{$\begin{array}{l}\text { Payment } \\
\text { rate } \\
{[4]} \\
\end{array}$} & \multirow{2}{*}{$\begin{array}{c}\text { Maximum } \\
\text { benefit } \\
\% \text { of } \\
\text { APW } \\
{[5]} \\
\end{array}$} & \multicolumn{2}{|c|}{ Tests on } & \multirow{2}{*}{$\begin{array}{c}\text { Permitted employment or } \\
\text { earnings disregards } \\
{[7]} \\
\end{array}$} & \multirow{2}{*}{$\begin{array}{c}\text { Additions for dependent } \\
\text { family members } \\
{[8]} \\
\end{array}$} \\
\hline & & & & & & & Assets & $\begin{array}{l}\text { Income } \\
\text { 6] }\end{array}$ & & \\
\hline \multirow[b]{2}{*}{ Australia } & 1985 & \multirow[b]{2}{*}{--} & \multirow[b]{2}{*}{7} & \multirow[b]{2}{*}{ No limit } & \multirow[b]{2}{*}{ Fixed amount } & 22 & \multirow[b]{2}{*}{ Yes } & \multirow[b]{2}{*}{ Family } & $\begin{array}{c}\text { Dis regard } 5 \% \text { of } A P W \text {, then } \\
\text { taper rate } 50 \% \text { rising to } \\
100 \% \text {. }\end{array}$ & $\begin{array}{l}\text { Up to } 4 \% \text { of APW for each child } \\
\text { under age } 16 \text { ( } 25 \text { if dependent } \\
\text { student). Partner allowance. }\end{array}$ \\
\hline & 1995 & & & & & 22 & & & $\begin{array}{l}\text { Disregard } 3 \% \text { of APW (1995: } \\
5 \%), 50 \% \text { withdrawal up to } \\
7 \% \text { of APW (1995: } 11 \%) \\
70 \% \text { above. Couple: no UA } \\
\text { for higher earner once } \\
\text { income above } 29 \% \text { of APW } \\
\text { (1995: } 37 \%), \text { spouse's UA } \\
\text { reduced by } 70 \% \text { for earnings } \\
\text { above this amount. }\end{array}$ & $\begin{array}{l}\text { Parenting payment for } \\
\text { dependent children (generally } \\
\text { replaces UA). Partner } \\
\text { allowance. }\end{array}$ \\
\hline \multirow{3}{*}{ Austria $^{3}$} & 1985 & \multirow{3}{*}{$\begin{array}{l}\text { Exhausted } \\
\text { Ul benefit }\end{array}$} & \multirow{3}{*}{--} & \multirow{3}{*}{ No limit } & \multirow{3}{*}{$\begin{array}{c}92 \% \text { of basic } \\
\text { UI benefit (can } \\
\text { be higher for } \\
\text { low UI } \\
\text { benefits) }\end{array}$} & 36 & \multirow{3}{*}{ Yes } & \multirow{3}{*}{ Family } & \multirow{3}{*}{$\begin{array}{l}\text { higher dis regards / income } \\
\text { limits for families with } \\
\text { children }\end{array}$} & About $3 \%$ of APW for each \\
\hline & 1995 & & & & & 48 & & & & dant. \\
\hline & 2005 & & & & & 51 & & & & $\begin{array}{c}\text { About } 1 \% \text { of APW for each } \\
\text { dependant. }\end{array}$ \\
\hline \multirow{3}{*}{ Finland } & 1985 & \multirow{3}{*}{--} & \multirow{3}{*}{5} & \multirow{3}{*}{ No limit } & \multirow{3}{*}{ Fixed amount } & 26 & \multirow{3}{*}{--} & Family & Information not available. & $\begin{array}{l}8 \%, 11 \%, 14 \% \text { of } \mathrm{APW} \text { for } 1,2 \\
\text { and } 3+\text { children respectively. }\end{array}$ \\
\hline & 1995 & & & & & 23 & & \multirow{2}{*}{$\begin{array}{c}\text { Family } \\
\text { but no } \\
\text { means } \\
\text { test for } \\
\text { first } 180 \\
\text { days after } \\
\text { Ul } \\
\text { exhausted }\end{array}$} & $\begin{array}{l}\text { Disregard of } 34 \% \text { of APW, } \\
\text { higher if couple or children. } \\
75 \% \text { withdrawal rate above. }\end{array}$ & $\begin{array}{l}5 \%, 7 \%, 9 \% \text { for } 1,2 \text { and } 3+ \\
\text { children respectively. }\end{array}$ \\
\hline & 2005 & & & & & 20 & & & $\begin{array}{l}\text { Disregard of } 10 \% \text { of APW, } \\
\text { higher if couple or children. } \\
75 \% \text { withdrawal rate above, } \\
\text { lower rate if dependants. }\end{array}$ & $\begin{array}{c}4 \%, 6 \%, 7 \% \text { of } \mathrm{APW} \text { for } 1,2 \text { and } \\
3+\text { children respectively. }\end{array}$ \\
\hline
\end{tabular}


DELSA/ELSA/WD/SEM $(2011) 7$

Table A3. Unemployment assistance: main policy changes. ${ }^{1}$ (continued)

\begin{tabular}{|c|c|c|c|c|c|c|c|c|c|c|}
\hline & & \multirow{2}{*}{$\begin{array}{l}\text { Employment } \\
\text { record in } \\
\text { months }{ }^{2} \\
{[1]}\end{array}$} & \multirow{2}{*}{$\begin{array}{c}\text { Waiting } \\
\text { period } \\
\text { (days) } \\
{[2]} \\
\end{array}$} & \multirow{2}{*}{$\begin{array}{c}\text { Duration } \\
\text { (months) } \\
{[3]}\end{array}$} & \multirow{2}{*}{$\begin{array}{l}\text { Payment } \\
\text { rate } \\
{[4]}\end{array}$} & \multirow{2}{*}{$\begin{array}{c}\text { Maximum } \\
\text { benefit } \\
\% \text { of } \\
\text { APW } \\
{[5]} \\
\end{array}$} & \multicolumn{2}{|c|}{ Tests on } & \multirow{2}{*}{$\begin{array}{l}\text { Permitted employment and } \\
\text { disregards }\end{array}$} & \multirow{2}{*}{$\begin{array}{c}\text { Additions for dependent } \\
\text { family members } \\
{[8]} \\
\end{array}$} \\
\hline & & & & & & & Assets & Income & & \\
\hline \multirow{3}{*}{ France } & 1985 & $\begin{array}{l}\text { Exhausted } \\
\text { Ul benefit }\end{array}$ & \multirow{3}{*}{--} & No limit & \multirow{3}{*}{ Fixed amount } & 18 & \multirow{3}{*}{-- } & \multirow{3}{*}{ Family } & no information & no information \\
\hline & 1995 & $\begin{array}{l}\text { (1) } \\
\text { Exhausted } \\
\text { Ul benefit }\end{array}$ & & \multirow{2}{*}{$\begin{array}{l}6 \text { months } \\
\text { (renewable) }\end{array}$} & & 23 & & & $\begin{array}{l}\text { Disregard of } 31 \% \text { of APW, } \\
\text { substantially higher for } \\
\text { couples. }\end{array}$ & \multirow{2}{*}{$\begin{array}{l}\text { For older workers depending on } \\
\text { age and employment record. }\end{array}$} \\
\hline & 2005 & $\begin{array}{l}\text { (2) } 60 \\
\text { months in } \\
\text { last } 120\end{array}$ & & & & 21 & & & $\begin{array}{l}\text { Disregard of } 28 \% \text { of APW, } \\
\text { substantially higher for } \\
\text { couples. }\end{array}$ & \\
\hline \multirow{3}{*}{ Germany } & 1985 & \multirow{2}{*}{$\begin{array}{l}\text { Exhausted } \\
\text { Ul, or } 6 \\
\text { months in } \\
\text { last } 12\end{array}$} & \multirow{3}{*}{--} & \multirow{3}{*}{ No limit } & $\begin{array}{l}56 \% \text { of } \\
\text { previous net } \\
\text { earnings }\end{array}$ & -- & \multirow{3}{*}{ Yes } & \multirow{3}{*}{ Family } & \multirow{2}{*}{$\begin{array}{l}\text { Total loss if w orking } 18 \text { hours } \\
\text { or more a w eek, benefit reduced } \\
\text { w ith } 100 \% \text { taper if w orking less. } \\
\text { Spouse net income up to about } \\
20 \% \text { of APW is disregarded, } \\
\text { then taper of around } 50 \% .\end{array}$} & Rate +2 pct points if children \\
\hline & 1995 & & & & $\begin{array}{l}53 \% \text { of } \\
\text { previous net } \\
\text { earnings }\end{array}$ & 53 & & & & Rate +4 pct points if children. \\
\hline & $2005^{4}$ & -- & & & Fixed amount & 12 & & & $\begin{array}{l}85 \% \text { taper up to } 14 \% \text { of } \\
\text { APW, } 70 \% \text { up to } 31 \% \text { of } \\
\text { APW, } 85 \% \text { up to } 52 \% \text { of } \\
\text { APW. } \\
\end{array}$ & $\begin{array}{l}\text { Additions for each child } \\
\text { depending on age. }\end{array}$ \\
\hline \multirow{3}{*}{$\begin{array}{l}\text { United } \\
\text { Kingdom }\end{array}$} & 1985 & \multicolumn{9}{|c|}{ None, see table on "social assistance" } \\
\hline & 1995 & \multirow{2}{*}{-- } & \multirow{2}{*}{--} & \multirow{2}{*}{ No limit } & \multirow{2}{*}{ Fixed amount } & 16 & \multirow{2}{*}{ Yes } & \multirow{2}{*}{ Family } & \multirow{2}{*}{$\begin{array}{c}\text { Disregard of } 1 \% \text { of APW } \\
(1995: 2 \%), \text { higher for } \\
\text { couples and lone parents. } \\
\text { Other forms of income } \\
\text { reduce benefits on a } 1 / 1 \\
\text { basis. }\end{array}$} & $\begin{array}{c}9 \% \text { of APW for spouse, plus } \\
\text { various premiums for families } \\
\text { (see table on social assistance) }\end{array}$ \\
\hline & 2005 & & & & & 14 & & & & $\begin{array}{c}8 \% \text { of APW for spouse, plus } \\
\text { various premiums for families } \\
\text { (see table on social assistance) }\end{array}$ \\
\hline
\end{tabular}

1. For a 40-year-old single worker without children. All benefit amounts are shown on an annualised basis. "--" indicates that no information is available or not applicable.

UI $=$ after exhausting Ull benefits.

3. Rate can be increased to $95 \%$ for low UI levels.

4. As of 1st January 2005, unemployment assistance and social assistance for persons who are able to work were combined into one benefit, the basic jobseekers allowance (Unemployment Benefit II). Source: OECD tax-benefit policy database (www.oecd.org/els/social/workincentives). 
Table A4. Social assistance: main policy changes. ${ }^{1}$

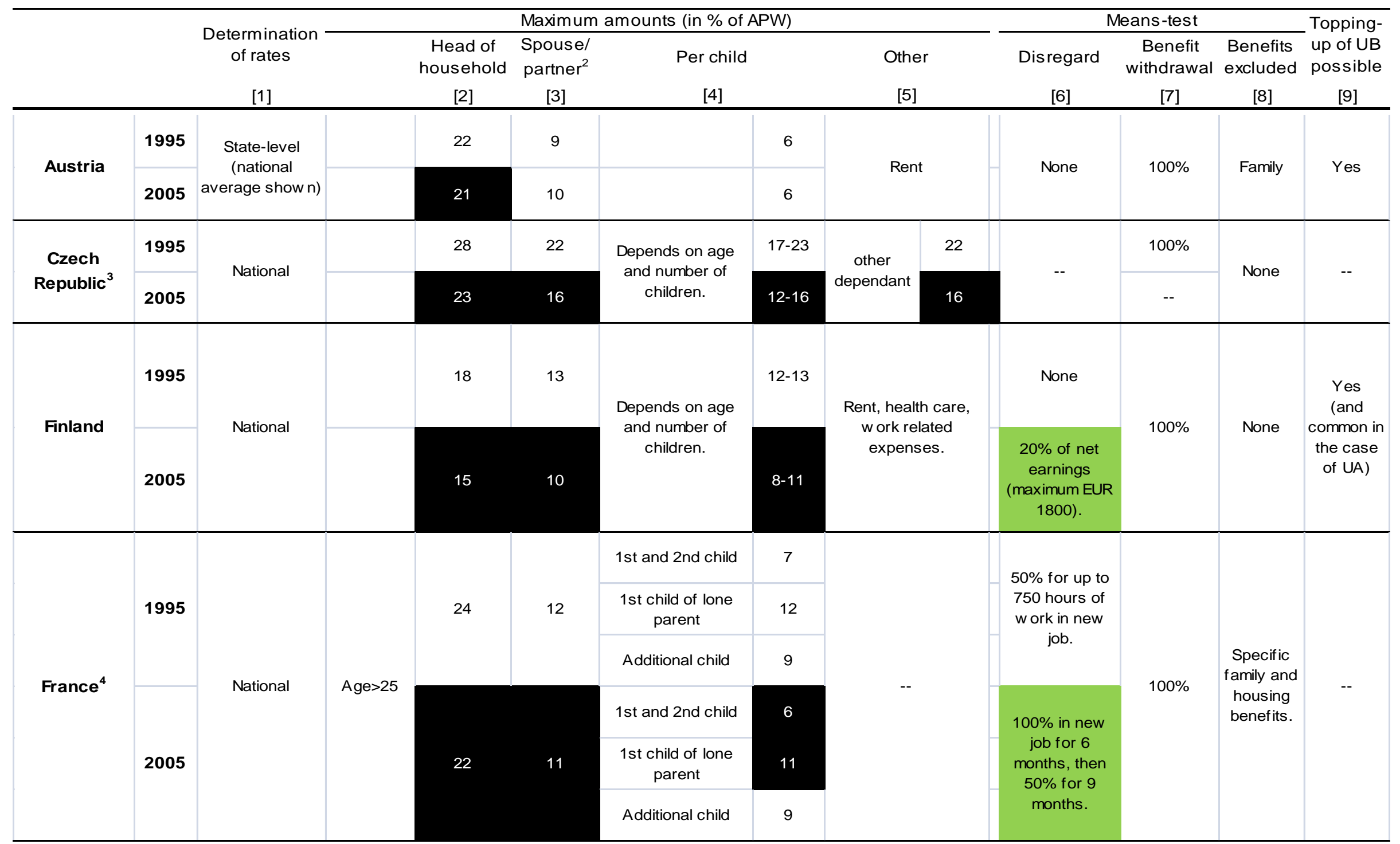


DELSA/ELSA/WD/SEM $(2011) 7$

Table A4. Social assistance: main policy changes. ${ }^{1}$ (continued)

\begin{tabular}{|c|c|c|c|c|c|c|c|c|c|c|c|c|c|}
\hline & & \multirow{3}{*}{$\begin{array}{c}\text { Determination } \\
\text { of rates } \\
{[1]} \\
\end{array}$} & \multicolumn{7}{|c|}{ Maximum amounts (in \% of APW) } & \multicolumn{3}{|c|}{ Means-test } & \multirow{3}{*}{$\begin{array}{c}\text { Topping } \\
\text { up of UB } \\
\text { possible } \\
{[9]}\end{array}$} \\
\hline & & & & $\begin{array}{c}\text { Head of } \\
\text { household }\end{array}$ & $\begin{array}{l}\text { Spouse/ } \\
\text { partner }^{2}\end{array}$ & Per child & & Othe & & Disregard & $\begin{array}{c}\text { Benefit } \\
\text { withdrawal }\end{array}$ & $\begin{array}{l}\text { Benefits } \\
\text { excluded }\end{array}$ & \\
\hline & & & & {$[2]$} & {$[3]$} & [4] & & [5] & & [6] & [7] & [8] & \\
\hline \multirow[t]{2}{*}{ Germany } & 1995 & $\begin{array}{l}\text { State-level } \\
\text { (national avg } \\
\text { show } n \text { ) }\end{array}$ & & 13 & 11 & Varies by age. & $6-10$ & $\begin{array}{l}\text { Extra allow } \\
\text { additional } \\
\text { rent, heatin }\end{array}$ & $\begin{array}{l}\text { ces for } \\
\text { eeds, } \\
\text { costs. }\end{array}$ & $\begin{array}{l}\text { Applies to net } \\
\text { earnings to } 5 \% \\
\text { APW. }\end{array}$ & $100 \%$ & $\begin{array}{l}\text { Family, } \\
\text { housing } \\
\text { and child- } \\
\text { care } \\
\text { benefits }\end{array}$ & -- \\
\hline & 2005 & National & \multicolumn{11}{|c|}{$\begin{array}{c}\text { those capable of w orking now receive UA instead (as of } 1 \text { st Jan 2005, UA and SA for those able } \\
\text { Benefit Il" basic jobseekers allow ance) }\end{array}$} \\
\hline \multirow{3}{*}{$\begin{array}{c}\text { Japan }^{3} \\
\text { (Osaka/ } \\
\text { Tokyo) }\end{array}$} & 1995 & \multirow{3}{*}{$\begin{array}{l}\text { Regionally } \\
\text { determined }\end{array}$} & \multirow{3}{*}{$\begin{array}{l}\text { Depends } \\
\text { on age of } \\
\text { family } \\
\text { members. }\end{array}$} & \multirow[t]{3}{*}{25} & \multirow[t]{3}{*}{13} & \multirow{3}{*}{$\begin{array}{l}\text { Depends on age } \\
\text { and number of } \\
\text { children. }\end{array}$} & 8 & \multicolumn{2}{|c|}{$\begin{array}{l}\text { Medical, long-term } \\
\text { care, occupational, } \\
\text { education, maternity } \\
\text { and funeral aid. }\end{array}$} & \multirow{3}{*}{$\begin{array}{c}\text { Applies to net } \\
\text { earnings of up } \\
\text { to } 10 \% \text { of } \\
\text { APW. }\end{array}$} & \multirow{3}{*}{$100 \%$} & \multirow{3}{*}{--} & \multirow{3}{*}{ Yes } \\
\hline & \multirow[t]{2}{*}{2005} & & & & & & 7 & $\begin{array}{l}\text { Housing } \\
\text { costs. } \\
\text { Medical, lo } \\
\text { care, occu } \\
\text { education, } \\
\text { and fune }\end{array}$ & $\begin{array}{l}20 \\
\text { g-term } \\
\text { ational, } \\
\text { aternity } \\
\text { I aid. }\end{array}$ & & & & \\
\hline & & & & & & & & $\begin{array}{l}\text { Housing } \\
\text { costs. }\end{array}$ & 20 & & & & \\
\hline \multirow{3}{*}{$\begin{array}{l}\text { United } \\
\text { Kingdom }\end{array}$} & 1985 & \multirow{3}{*}{ National } & & 17 & 10 & $\begin{array}{l}\text { Depends on age of } \\
\text { children. }\end{array}$ & 6-13 & -- & & -- & \multirow{3}{*}{$100 \%$} & & \multirow{3}{*}{ Yes } \\
\hline & 1995 & & \multirow{2}{*}{$\begin{array}{l}\text { Age }>24 \text { or } \\
\text { lone } \\
\text { parent. }\end{array}$} & 16 & 9 & $\begin{array}{l}\text { Depends on age } \\
\text { and number of } \\
\text { children. }\end{array}$ & $5-12$ & \multirow{2}{*}{$\begin{array}{l}\text { Family } \\
\text { premium. }\end{array}$} & \multirow{2}{*}{4} & $\begin{array}{l}2 \% \text { of APW, } \\
\text { higher for } \\
\text { couples and } \\
\text { lone parents. }\end{array}$ & & $\begin{array}{l}\text { +Council } \\
\text { Tax Ben }\end{array}$ & \\
\hline & 2005 & & & 14 & 8 & \multicolumn{2}{|c|}{$\begin{array}{l}\text { From 2003, extra support } \\
\text { through Child Tax Credit } \\
\text { (means-tested, w ithdraw } n \\
\text { only at higher earnings). }\end{array}$} & & & $\begin{array}{c}1 \% \text { of APW, } \\
\text { higher for } \\
\text { couples and } \\
\text { lone parents. }\end{array}$ & & $\begin{array}{l}\text { Housing }+\mathrm{C} \\
\text { ouncil Tax } \\
\text { Ben, Child } \\
\text { Tax Credit } \\
\end{array}$ & \\
\hline \multirow{3}{*}{$\begin{array}{l}\text { United } \\
\text { States }^{5}\end{array}$} & $1985^{6}$ & \multirow{3}{*}{ National rates } & & 6 & 5 & \multirow{3}{*}{$\begin{array}{c}\text { varies with number } \\
\text { of children }\end{array}$} & \multirow{3}{*}{$\begin{array}{c}4 \\
\text { (1st } \\
\text { child) }\end{array}$} & \multirow{3}{*}{\multicolumn{2}{|c|}{$\begin{array}{c}\text { certain housing (rent) } \\
\text { expenses }\end{array}$}} & -- & \multirow{3}{*}{$30 \%$} & \multirow{3}{*}{$\begin{array}{l}\text { Earned } \\
\text { Income } \\
\text { Tax Credit }\end{array}$} & \multirow{3}{*}{ Yes } \\
\hline & 1995 & & & 5 & 4 & & & & & $\begin{array}{l}\text { Occasional } \\
\text { income up to }\end{array}$ & & & \\
\hline & 2005 & & & 5 & 4 & & & & & USD 120. & & & \\
\hline
\end{tabular}

1. All amounts are shown on an annualised basis. "--"indicates that no information is available or not applicable.

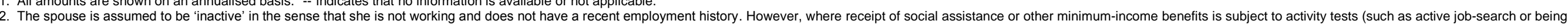
'available' for work), these requirements are assumed to be met. Available information on such requirements is summarised in the country chapters on www.oecd.org/els/social/workincentives.

3. The benefit is made up of two parts: an individual amount depending on the age of the child (and sometimes the adult) concerned; and a household amount that depends on the size of the household.

4. The benefit is also available for people under 25 years old with dependent children.
5. Amounts shown for food stamps only. See Family Benefits table for information on the Temporary Assistance for Needy Families (TANF) / Assistance for Families with Dependent Children (AFDC) programmes.

Source: OECD tax-benefit policy database (www.oecd.org/els/social/workincentives) 
Table A5. Family benefits (for children aged 3+): main policy changes. ${ }^{1}$

\begin{tabular}{|c|c|c|c|c|c|c|c|}
\hline & & \multirow{3}{*}{$\begin{array}{c}\text { Maximum } \\
\text { benefit for } \\
\text { one child } \\
\text { aged 3-12 } \\
\text { (\% of APW) } \\
{[1]}\end{array}$} & \multicolumn{2}{|c|}{$\begin{array}{l}\text { Benefit amount per } \\
\text { additional child varies } \\
\qquad \text { with }^{2}\end{array}$} & \multirow{2}{*}{$\begin{array}{l}\text { Upper age } \\
\text { limit for } \\
\text { children } \\
\text { (student) }\end{array}$} & \multirow[t]{2}{*}{ Means test on } & \multirow[t]{3}{*}{ Observations } \\
\hline & & & $\begin{array}{l}\text { Age of } \\
\text { child }\end{array}$ & $\begin{array}{l}\text { Number of } \\
\text { children }\end{array}$ & & & \\
\hline & & & [2] & [3] & [4] & [5] & \\
\hline \multirow{6}{*}{ Australia } & \multirow{2}{*}{1985} & 1 & 0 & + & $15(24)$ & No & $\begin{array}{l}274 \text { (1st child), } 390.6 \text { (2nd child), } 468 \text { (3th and 4th } \\
\text { child), } 546.6 \text { ( } 5 \text { th till 99th child) }\end{array}$ \\
\hline & & 4 & 0 & 0 & $15(24)$ & Family taxable income. & -- \\
\hline & \multirow{2}{*}{1995} & 2 & 0 & 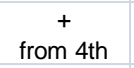 & $15(24)$ & \multirow{2}{*}{ Family earned income. } & -- \\
\hline & & 5 & $+/-$ & 0 & $15(18)$ & & Support for families with low income. \\
\hline & \multirow[b]{2}{*}{2005} & 7 & $+/-$ & 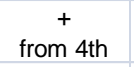 & $20(24)$ & Family earned income. & Support towards cost of raising children. \\
\hline & & 6 & - & 0 & $15(18)$ & $\begin{array}{l}\text { Earned income of secondary } \\
\quad \text { earner in a couple. }\end{array}$ & Support for families with one main income. \\
\hline \multirow{3}{*}{ Austria } & 1985 & 7 & \multirow{2}{*}{+} & \multirow{2}{*}{0} & 18 & \multirow{3}{*}{ No } & $\begin{array}{l}\text { Child up to age 11: } 12000 \text {. Thereafter: } 12600 \\
\text { schillings. }\end{array}$ \\
\hline & 1995 & 6 & & & & & \\
\hline & 2005 & 6 & $+/-$ & + & $19(27)$ & & $\begin{array}{l}\text { supplement for low-income families with multiple } \\
\text { children. }\end{array}$ \\
\hline \multirow{2}{*}{$\begin{array}{l}\text { Czech } \\
\text { Republic }\end{array}$} & 1995 & 9 & + & \multirow{2}{*}{0} & \multirow{2}{*}{$14(25)$} & \multirow{2}{*}{$\begin{array}{l}\text { Family net income relative to } \\
\text { minimum living standard. }\end{array}$} & $\begin{array}{l}\text { Universal basic benefit plus additional means tested } \\
\text { component (subject to income limit of } 2 x \text { minimum } \\
\text { living standard). }\end{array}$ \\
\hline & 2005 & 4 & $+/-$ & & & & $\begin{array}{l}\text { Three benefit levels: increased, basic or reduced, } \\
\text { depending on income }\end{array}$ \\
\hline \multirow{3}{*}{ Finland } & 1985 & 3 & - & \multirow{3}{*}{+} & 15 & \multirow{3}{*}{ No } & $\begin{array}{l}\text { Separate child deductions/tax allowances for children } \\
\text { (abolished in 1994). }\end{array}$ \\
\hline & 1995 & 5 & \multirow{2}{*}{0} & & 16 & & \\
\hline & 2005 & 4 & & & 16 & & \\
\hline \multirow{3}{*}{ France } & 1985 & $\begin{array}{c}0 \\
\text { (7 for two } \\
\text { children) }\end{array}$ & + & + & $16(19)$ & No & $\begin{array}{c}\text { progressively higher amounts for 3rd and subsequent } \\
\text { children }\end{array}$ \\
\hline & 1995 & $\begin{array}{c}0 \\
\text { (7 for two } \\
\text { children) }\end{array}$ & + & + & 20 & No & $\begin{array}{c}\text { progressively higher amounts for 3rd and subsequent } \\
\text { children }\end{array}$ \\
\hline & 2005 & $\begin{array}{c}0 \\
\text { (6 for two } \\
\text { children) }\end{array}$ & + & + & 20 & No & $\begin{array}{c}\text { progressively higher amounts for 3rd and subsequent } \\
\text { children }\end{array}$ \\
\hline \multirow{3}{*}{ Germany } & 1985 & 2 & 0 & + & $15(26)$ & $\begin{array}{l}\text { Yes, for allowance for } 2 \text { nd } \\
\text { and further children. }\end{array}$ & \multirow{2}{*}{$\begin{array}{l}\text { Benefits for } 2 \text { nd }(2 x) \text { and further children ( } 3 x \text { and more) } \\
\text { are much higher than for } 1 \text { st but are somewhat } \\
\text { reduced if family income exceeds limit. Low-income } \\
\text { families receive a supplement of about } 2 \% \text { of APW. }\end{array}$} \\
\hline & 1995 & 1 & 0 & + & $16(27)$ & $\begin{array}{l}\text { Yes, for allowance for } 2 \text { nd } \\
\text { and further children. }\end{array}$ & \\
\hline & 2005 & 5 & 0 & $\stackrel{+}{+}$ & $18(27)$ & No & $\begin{array}{l}\text { Non-wastable tax credit in the form of a monthly tax } \\
\text { refund (a tax allowance for high-income earners if this } \\
\text { results in a greater tax reduction). }\end{array}$ \\
\hline
\end{tabular}


DELSA/ELSA/WD/SEM(2011)7

Table A5. Family benefits (for children aged 3+): main policy changes. ${ }^{1}$ (continued)

\begin{tabular}{|c|c|c|c|c|c|c|c|}
\hline & & \multirow{3}{*}{$\begin{array}{c}\text { Maximum } \\
\text { benefit for } \\
\text { one child } \\
\text { aged } 3-12 \\
\text { (\% of APW) } \\
{[1]}\end{array}$} & \multicolumn{2}{|c|}{$\begin{array}{l}\text { Benefit amount per } \\
\text { additional child varies } \\
\text { with }^{2}\end{array}$} & \multirow{2}{*}{$\begin{array}{l}\text { Upper age } \\
\text { limit for } \\
\text { children } \\
\text { (student) }\end{array}$} & \multirow[t]{2}{*}{ Means test on } & \multirow[t]{3}{*}{ Observations } \\
\hline & & & $\begin{array}{l}\text { Age of } \\
\text { child }\end{array}$ & $\begin{array}{l}\text { Number of } \\
\text { children }\end{array}$ & & & \\
\hline & & & [2] & [3] & {$[4]$} & [5] & \\
\hline \multirow{3}{*}{ Italy ${ }^{3}$} & 1985 & 1 & 0 & 0 & $17(25)$ & \multirow{3}{*}{ Family taxable income } & \multirow{3}{*}{$\begin{array}{l}\text { Majority of taxable family income must be from } \\
\text { employment in order to qualify for the benefit. Benefit } \\
\text { also paid for adult dependants }\end{array}$} \\
\hline & 1995 & 2 & 0 & + & 18 & & \\
\hline & 2005 & 4 & 0 & + & 17 & & \\
\hline \multirow{2}{*}{ Japan } & 1985 & 0 & 0 & 0 & 15 & \multirow{2}{*}{$\begin{array}{l}\text { Gross income less earned } \\
\text { income tax deduction. }\end{array}$} & $\begin{array}{l}2 \% \text { of APW per child from 3rd child and further } \\
\text { children. }\end{array}$ \\
\hline & $\begin{array}{l}1995 \\
2005\end{array}$ & $\begin{array}{l}0 \\
1 \\
\end{array}$ & $\begin{array}{l}0 \\
0\end{array}$ & $\stackrel{+}{+}$ & $\begin{array}{l}2 \\
9\end{array}$ & & $\begin{array}{l}\text { Amount per child doubles as from } 3 \text { rd child. (to } 3 \% \text { of } \\
\text { APW in 2005). }\end{array}$ \\
\hline \multirow{4}{*}{$\begin{array}{l}\text { United } \\
\text { Kingdom }\end{array}$} & 1985 & 7 & \multirow{4}{*}{0} & $\begin{array}{l}0 \text { (- if lone } \\
\text { parent) }\end{array}$ & $15(18)$ & \multirow{3}{*}{ No } & $\begin{array}{l}\text { First child: higher rate if lone parent }(577) \text { (normally: } \\
356,2) \text {. Fixed rate from } 2 \text { nd child }(356,2) \text {. }\end{array}$ \\
\hline & 1995 & 4 & & - & $14(18)$ & & \multirow{2}{*}{ Fixed rate from 2nd child. } \\
\hline & & 4 & & - & $15(18)$ & & \\
\hline & 2005 & 5 & & - & $15(18)$ & $\begin{array}{c}\text { Yes, withdrawn only at higher } \\
\text { earnings levels. }\end{array}$ & Child Tax Credit \\
\hline \multirow{4}{*}{$\begin{array}{l}\text { United } \\
\text { States }^{3} \\
\text { (Michigan) }\end{array}$} & 1985 & 5 & \multirow{4}{*}{0} & \multirow[b]{3}{*}{$+/-$} & \multirow[b]{3}{*}{$18(19)$} & \multirow{3}{*}{$\begin{array}{l}\text { Earned income minus various } \\
\text { deductions and excluding } \\
\text { food stamps, EITC }\end{array}$} & \multirow{2}{*}{$\begin{array}{l}\text { Mainly for lone parents. Assistance to Families with } \\
\text { Dependent Children (AFDC) benefit amounts vary by } \\
\text { State. }\end{array}$} \\
\hline & 1995 & 4 & & & & & \\
\hline & \multirow[t]{2}{*}{2005} & 3 & & & & & $\begin{array}{l}\text { Mainly for lone parents. Temporary Assistance for } \\
\text { Needy Families (TANF, introduced in 1996) benefit } \\
\text { amounts and durations vary by State (federal 5-year } \\
\text { time limit but most States have longer). }\end{array}$ \\
\hline & & 3 & & 0 & 17 & $\begin{array}{l}\text { reduced at high earnings } \\
\text { levels }\end{array}$ & $\begin{array}{l}\text { Child Tax Credit (introduced 1998). Since } 2001 \\
\text { partially refundable for earnings }>30 \% \text { of APW. }\end{array}$ \\
\hline
\end{tabular}

1. Family benefits including non-wastable tax credits. All benefit amounts are shown on an annualised basis. "--" indicates that no information is available or not applicable. In general family benefits are not taxable unless otherwise indicated.

2. "+": increases, "-": decreases, "0": remains the same, "+/-": increases or decreases (e.g., higher rates to the youngest and oldest age groups).

3. Benefit amount for the first child is calculated as the difference in benefit between a three-member and a two-member household. Source: OECD tax-benefit policy database (www.oecd.org/els/social/workincentives). 
Table A6. Personal income tax: main policy changes.

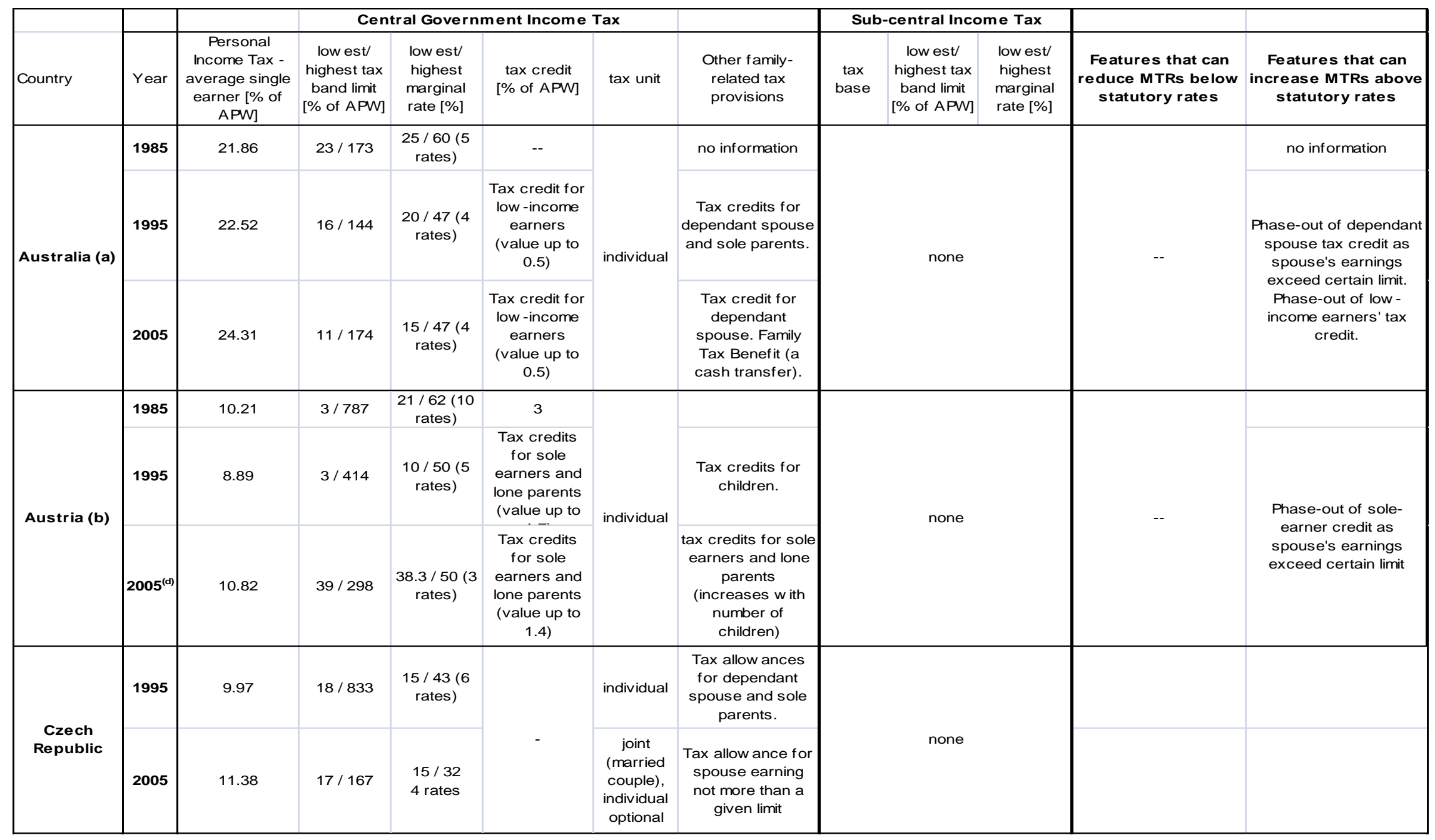


Table A6. Personal income tax: main policy changes. (continued)

\begin{tabular}{|c|c|c|c|c|c|c|c|c|c|c|c|c|}
\hline \multirow[b]{2}{*}{ Country } & \multirow[b]{2}{*}{ Year } & \multirow[b]{2}{*}{$\begin{array}{c}\text { Personal } \\
\text { Income Tax } \\
\text { paid by } \\
\text { average single } \\
\text { earner [\% of } \\
\end{array}$} & \multicolumn{4}{|c|}{ Central Government Income Tax } & \multirow[b]{2}{*}{$\begin{array}{l}\text { Other family- } \\
\text { related tax } \\
\text { provisions }\end{array}$} & \multicolumn{3}{|c|}{ Sub-central Income Tax } & \multirow[b]{2}{*}{$\begin{array}{l}\text { Features that can } \\
\text { reduce MTRs below } \\
\text { statutory rates }\end{array}$} & \multirow[b]{2}{*}{$\begin{array}{c}\text { Features that can } \\
\text { increase MTRs above } \\
\text { statutory rates }\end{array}$} \\
\hline & & & $\begin{array}{c}\text { low est/ } \\
\text { highest tax } \\
\text { band limit } \\
\text { [\% of APW] }\end{array}$ & $\begin{array}{l}\text { lowest/ } \\
\text { highest } \\
\text { marginal } \\
\text { rate [\%] }\end{array}$ & $\begin{array}{l}\text { tax credit } \\
{[\% \text { of APW] }}\end{array}$ & tax unit & & $\begin{array}{c}\operatorname{tax} \\
\text { base }\end{array}$ & $\begin{array}{c}\text { low est } / \text { high } \\
\text { est tax } \\
\text { band limit } \\
\text { [\% of APW] }\end{array}$ & $\begin{array}{l}\text { low est } / \text { high } \\
\text { est marginal } \\
\text { rate [\%] }\end{array}$ & & \\
\hline \multirow{3}{*}{ Finland } & 1985 & 30.51 & -- & $\begin{array}{l}6 / 51(11 \\
\text { rates })\end{array}$ & \multirow{3}{*}{--} & \multirow{3}{*}{ individual } & \multirow{3}{*}{--} & TYI & -- & $\begin{array}{c}18.75 \\
\text { (maximum) }\end{array}$ & \multicolumn{2}{|c|}{ no information } \\
\hline & 1995 & 29.26 & $32 / 215$ & $\begin{array}{c}7 / 39(6 \\
\text { rates) }\end{array}$ & & & & TYI & -- & $\begin{array}{c}20 \\
\text { (maximum) }\end{array}$ & $\begin{array}{c}\text { For local government } \\
\text { and church taxes a tax } \\
\text { deduction for low - } \\
\text { income earners (value } \\
\text { up to 1.5) }\end{array}$ & -- \\
\hline & 2005 & 24.16 & $39 / 186$ & $\begin{array}{c}10.5 / 33.5 \\
(5 \text { rates })\end{array}$ & & & & $\begin{array}{c}\text { Income } \\
\left(\begin{array}{c}=c e n t r a \\
1)\end{array}\right.\end{array}$ & 2 & $\begin{array}{c}18.3 \\
\text { (national } \\
\text { average) }\end{array}$ & $\begin{array}{l}\text { Earned income tax } \\
\text { allow ance of } 20 \% \text { of } \\
\text { taxable earnings } \\
\text { above } 11 \% \text { of AW }\end{array}$ & $\begin{array}{l}\text { Phase out of earned } \\
\text { income tax allow ance }\end{array}$ \\
\hline \multirow[b]{3}{*}{ France (c) } & 1985 & 7.40 & $19 / 290$ & $5 / 65(10$ & & \multirow[b]{3}{*}{$\begin{array}{c}\text { joint } \\
\text { (family) }\end{array}$} & & \multirow{3}{*}{\multicolumn{3}{|c|}{ none }} & & \\
\hline & 1995 & 8.78 & $19 / 204$ & $\begin{array}{c}12 / 56.8(6 \\
\text { rates })\end{array}$ & -- & & & & & & & joint taxation \\
\hline & 2005 & 13.11 & $19 / 210$ & $\begin{array}{c}6.83 / 48.09 \\
6 \text { rates }\end{array}$ & $\begin{array}{c}\text { Refundable } \\
\text { employment- } \\
\text { conditional tax } \\
\text { credit } \\
\text { (value up to 2) } \\
\end{array}$ & & -- & & & & -- & $\begin{array}{l}\text { Joint taxation. phase-out } \\
\text { of employment- } \\
\text { conditional tax credit }\end{array}$ \\
\hline \multirow{3}{*}{ Germany (d) } & 1985 & 18.07 & $6 / 176$ & $\begin{array}{c}22 / 56 \\
\text { continuous } \\
\text { tariff, } \\
\text { formula- } \\
\text { based }\end{array}$ & \multirow{3}{*}{--} & \multirow{3}{*}{$\begin{array}{c}\text { joint } \\
\text { (married } \\
\text { couple), } \\
\text { individual } \\
\text { optional }\end{array}$} & \multirow{3}{*}{--} & \multirow{3}{*}{\multicolumn{3}{|c|}{ none }} & \multirow{3}{*}{--} & \multirow{3}{*}{ Joint taxation } \\
\hline & 1995 & 20.82 & $5 / 109$ & $\begin{array}{c}19 / 53 \\
\text { continuous } \\
\text { tariff } \\
\text { formula- } \\
\text { based }\end{array}$ & & & & & & & & \\
\hline & 2005 & 19.62 & $22 / 153$ & $\begin{array}{c}15 / 42 \\
\text { continuous } \\
\text { tariff } \\
\text { formula- } \\
\text { based }\end{array}$ & & & & & & & & \\
\hline \multirow{3}{*}{ Italy } & 1985 & 18.36 & $2 / 3003$ & $\begin{array}{l}18 / 65 \\
9 \text { rates }\end{array}$ & \multirow{3}{*}{--} & \multirow{3}{*}{ individual } & & \multirow{2}{*}{\multicolumn{3}{|c|}{ no information }} & \multirow{3}{*}{--} & \\
\hline & 1995 & 17.52 & 24 / 881 & $\begin{array}{l}10 / 51 \\
7 \text { rates }\end{array}$ & & & $\begin{array}{l}\text { Tax exemptions } \\
\text { for dependant }\end{array}$ & & & & & $\begin{array}{l}\text { Phase-out of depenent } \\
\text { spouse tax allow ance }\end{array}$ \\
\hline & $2005^{(\mathrm{e})}$ & 18.61 & $32 / 421$ & $\begin{array}{l}23 / 43 \\
4 \text { rates }\end{array}$ & & & $\begin{array}{c}\text { Tax allow ances } \\
\text { for dependant } \\
\text { family members }\end{array}$ & Income & -- & $\begin{array}{l}1.1 \\
\text { (typical } \\
\text { rate) }\end{array}$ & & $\begin{array}{c}\text { Phase-out of family tax } \\
\text { allow ance }\end{array}$ \\
\hline
\end{tabular}


Table A6. Personal income tax: main policy changes. (continued)

\begin{tabular}{|c|c|c|c|c|c|c|c|c|c|c|c|c|}
\hline \multirow[b]{2}{*}{ Country } & \multirow[b]{2}{*}{ Year } & \multirow[b]{2}{*}{\begin{tabular}{|c|} 
Personal \\
Income Tax \\
paid by \\
average single \\
earner [\% of \\
\end{tabular}} & \multicolumn{4}{|c|}{ Central Government Income Tax } & \multirow[b]{2}{*}{$\begin{array}{l}\text { Other family- } \\
\text { related tax } \\
\text { provisions }\end{array}$} & \multicolumn{3}{|c|}{ Sub-central Income Tax } & \multirow[b]{2}{*}{$\begin{array}{c}\text { Features that can } \\
\text { reduce MTRs below } \\
\text { statutory rates }\end{array}$} & \multirow[b]{2}{*}{$\begin{array}{c}\text { Features that can } \\
\text { increase MTRs above } \\
\text { statutory rates }\end{array}$} \\
\hline & & & $\begin{array}{c}\text { low est/ } \\
\text { highest tax } \\
\text { band limit } \\
{[\% \text { of APW] }}\end{array}$ & $\begin{array}{l}\text { low est/ } \\
\text { highest } \\
\text { marginal } \\
\text { rate [\%] }\end{array}$ & $\begin{array}{l}\text { tax credit } \\
{[\% \text { of APW] }}\end{array}$ & tax unit & & $\begin{array}{c}\text { tax } \\
\text { base }\end{array}$ & $\begin{array}{c}\text { low est/high } \\
\text { est tax } \\
\text { band limit } \\
\text { [\% of APW] }\end{array}$ & $\begin{array}{c}\text { low est } / \text { high } \\
\text { est marginal } \\
\text { rate [\%] }\end{array}$ & & \\
\hline \multirow[t]{2}{*}{ Japan } & 1995 & 6.42 & $10 / 757$ & $\begin{array}{l}10 / 50 \\
(5 \text { rates })\end{array}$ & n.a. & \multirow[t]{2}{*}{ individual } & $\begin{array}{c}\text { Tax allow ances } \\
\text { for spouse and } \\
\text { dependant family } \\
\text { members }\end{array}$ & TYs & - & 15 & -- & \\
\hline & 2005 & 5.85 & $9 / 425$ & $\begin{array}{l}10 / 37 \\
4 \text { rates }\end{array}$ & $\begin{array}{l}20 \% \text { of tax } \\
\text { liability (max. } \\
\text { value } 5 \text { ) }\end{array}$ & & $\begin{array}{l}\text { Tax allow ances } \\
\text { for dependant } \\
\text { family members }\end{array}$ & TYs & $0 / 177$ & $\begin{array}{c}5 / 13(3 \\
\text { rates) }\end{array}$ & -- & -- \\
\hline \multirow{3}{*}{$\begin{array}{l}\text { United } \\
\text { Kingdom (a) }\end{array}$} & 1985 & 22.26 & $26 / 496$ & $\begin{array}{c}30 / 60(6 \\
\text { rates })\end{array}$ & $\begin{array}{c}\text { Employment } \\
\text { conditional tax } \\
\text { credit (1986): } \\
\text { value up to } 15\end{array}$ & $\begin{array}{l}\text { joint } \\
\text { (married } \\
\text { couple) }\end{array}$ & & \multirow{3}{*}{\multicolumn{3}{|c|}{ none }} & & \\
\hline & 1995 & 18.23 & $23 / 181$ & $\begin{array}{c}20 / 40(6 \\
\text { rates })\end{array}$ & $\begin{array}{l}\text { Employment } \\
\text { conditional tax } \\
\text { credit for } \\
\text { w orking } \\
\text { families: value } \\
\text { up to } 19 \text { (adult }\end{array}$ & \multirow{2}{*}{ individual } & & & & & $\begin{array}{c}\text { Employment-conditional } \\
\text { tax credit results in } \\
\text { negative MTRs at the } \\
\text { point where entitlement } \\
\text { starts }\end{array}$ & $\begin{array}{c}\text { Phase-out of } \\
\text { employment-conditional } \\
\text { and family/child tax } \\
\text { credits }\end{array}$ \\
\hline & 2005 & 15.90 & $23 / 175$ & $\begin{array}{l}10 / 40(3 \\
\text { rates) }\end{array}$ & $\begin{array}{l}\text { Employment } \\
\text { conditional tax } \\
\text { credit: value } \\
\text { up to: } 24 \\
\text { (adult }+1\end{array}$ & & Child tax credit & & & & $\begin{array}{c}\text { Employment-conditional } \\
\text { tax credit results in } \\
\text { negative MTRs at the } \\
\text { point w here entitlement } \\
\text { starts }\end{array}$ & $\begin{array}{c}\text { Phase-out of } \\
\text { employment-conditional } \\
\text { and family/child tax } \\
\text { credits }\end{array}$ \\
\hline \multirow{3}{*}{$\begin{array}{l}\text { United } \\
\text { States }\end{array}$} & 1985 & 21.85 & $5 / 431$ & $\begin{array}{c}11 / 50(15 \\
\text { rates })\end{array}$ & $\begin{array}{c}\text { Employment } \\
\text { conditional tax } \\
\text { credit }\end{array}$ & \multirow{3}{*}{$\begin{array}{l}\text { joint } \\
\text { (married } \\
\text { couple), } \\
\text { individual } \\
\text { optional }\end{array}$} & much higher & TYs & -- & $\begin{array}{c}5.68 \text { (typical } \\
\text { rate) }\end{array}$ & \multirow{2}{*}{$\begin{array}{c}\text { Employment-conditional } \\
\text { tax credit increases } \\
\text { w ith earnings at low } \\
\text { earnings level }\end{array}$} & \multirow{2}{*}{$\begin{array}{c}\text { Phase-out of } \\
\text { employment-conditional } \\
\text { tax credit, joint taxation }\end{array}$} \\
\hline & 1995 & 18.11 & $24 / 988$ & $\begin{array}{c}15 / 39.6 \text { (5 } \\
\text { rates) }\end{array}$ & $\begin{array}{l}\text { Employment } \\
\text { conditional tax } \\
\text { credit: value } \\
\text { up to } 1\end{array}$ & & $\begin{array}{l}\text { employment- } \\
\text { conditional tax } \\
\text { credit for families }\end{array}$ & TYs & $3 / 12$ & $\begin{array}{c}3 / 7.4 \\
\text { (Detroit, } \\
\text { Michigan) }\end{array}$ & & \\
\hline & 2005 & 16.53 & $23 / 943$ & $\begin{array}{c}10 / 35(6 \\
\text { rates) }\end{array}$ & $\begin{array}{l}\text { Employment } \\
\text { conditional tax } \\
\text { credit: value } \\
\text { up to } 1\end{array}$ & & $\begin{array}{l}\text { as } 1995 \text {, plus child } \\
\text { tax credit }\end{array}$ & TYs & $2 / 9$ & $\begin{array}{l}2.5 / 6.4 \\
\text { (Detroit, } \\
\text { Michigan) }\end{array}$ & $\begin{array}{l}\text { Employment-conditional } \\
\text { and child-related tax } \\
\text { credits increase with } \\
\text { earnings at low levels }\end{array}$ & $\begin{array}{c}\text { Phase-out of } \\
\text { employment-conditional } \\
\text { and child-related tax tax } \\
\text { credits, joint taxation }\end{array}$ \\
\hline
\end{tabular}

Note: The tax band limits shown do not account for the tax exemptions available for holiday and end-of-year bonus payments. TYs: Taxable income (for central government purposes) modified for state government tax purposes; TYl: modified for local government tax purposes.
(a) For Australia and the UK, all with a non-calendar tax year, the rates and thresholds shown are those in effect as of 1 July and 5 April, respectively. (b) Lower tax rates of normally $6 \%$ apply to the 13 th and 14 th monthly salaries.

(c) Thresholds are in Euros. These are the rates applying to income earned in the year specified, to be paid in the following year. This table does not include the (limited) basic deduction of 10 per cent of taxable income nor the $20 \%$ supplementary deduction. Source: OECD tax-benefit policy database (www.oecd org/els/social/workincen 


\section{REFERENCES}

Adam, S. and J. Browne (2010), "Redistribution, Work Incentives and Thirty Years of UK Tax and Benefit Reform", IFS Working Paper No. 10/24, Institute for Fiscal Studies, London.

Atkinson, A. B., 2004, "Increased Income Inequality in OECD Countries and the Redistributive Impact of the Government Budget", in G. A. Cornia (eds), Inequality, Growth, and Poverty in an Era of Liberalization and Globalization, Oxford University Press. Oxford, pp. 220-48.

Atkinson, A.B. and T. Piketty, eds., (2010), Top Incomes: A Global Perspective, Oxford University Press, Oxford.

Atkinson, A. B., T. Piketty and E. Saez, (2011), “Top Incomes over a Century or More”, Journal of Economic Literature.

Atta-Darkua, V. and A. Barnard, (2010), "Distributional effects of direct taxes and social transfers (cash benefits)", in: A. B. Atkinson and E. Marlier, eds., Income and living conditions in Europe, Eurostat, Luxembourg.

Bargain, O. and T. Callan, 2010, "Analysing the effects of tax-benefit reforms on income distribution: a decomposition approach", Journal of Economic Inequality, v8, 1-21.

Bargain, O., M. Dolls, H. Immervoll, D. Neumann, A. Peichl, N. Pestel, S. Siegloch (2011), "Tax Policy and Income Inequality in the United States, 1978-2007: A Decomposition Approach", paper to be presented at the National Tax Association conference.

Bargain, O. and C. Keane, 2010, “Tax-Benefit Revealed Redistributive Preferences Over Time: Ireland 1987-2005”, Labour, 36.

Blackburn, M. L. and D. E. Bloom, 1994, "Changes in the structure of family income inequality in the US and other industrilaized nations during the 1980s", NBER Working Paper No. 4754, National Bureau of Economic Research, Cambridge, MA.

Carcillo. S and D. Grubb (2006), "From Inactivity to Work: The Role of Active Labour Market Policies", Social, Employment and Migration Working Papers, No. 36, OECD, Paris www.oecd.org/els/workingpapers.

D'Addio, A. C. and H. Immervoll (2010), "Earnings of men and women working in the private sector: enriched data for pensions and tax-benefit modeling", Social, Employment and Migration Working Papers, No. 108, OECD, Paris www.oecd.org/els/workingpapers.

Dardoni, V. and P. Lambert (2002), "Progressivity comparisons", Journal of Public Economics, 86, 99122.

Decoster, A. and G. van Camp (2001), "Redistributive Effects of the Shift from Personal Income Taxes to Indirect Taxes: Belgium 1988-93”, Fiscal Studies, 22(1), 79-106. 
Donaldson, D. and J.A. Weymark (1980), "A Single Parameter Generalization of the Gini Indices of Inequality", Journal of Economic Theory, 22, 67-86.

Duclos, J. Y., (2000), "Gini Indices and the Redistribution of Income", International Tax and Public Finance, 7(2), 142-62.

Fritzell, J., 1993, "Income inequality trends in the 1980's: a five country comparison", Acta Sociologica, $36,47-62$.

Giertz, S., J. Slemrod and E. Saez, "The Elasticity of Taxable Income with Respect to Marginal Tax Rates: A Critical Review", Journal of Economic Literature, forthcoming.

Glennerster, H., (2006), "Tibor Barna: The redistributive impact of taxes and social policies in the UK: 1937-2005”, CASE LSE STICERD Research Paper No. CASE115, London School of Economics.

Gottschalk, P., and T. M. Smeeding, 2000, "Empirical evidence on income inequality in industrial countries", in: A. B. Atkinson and F. Bourguignon (eds.), Handbook of Income Distribution, North Holland.

Gregg, P., R. Scutella and J. Wadsworth (2004), "Reconciling Workless Measures at the Individual and Household Level: Theory and Evidence from the United States, Britain, Germany, Spain and Australia”, CEP Discussion Paper No 635, London School of Economics.

Hagemann, R. P., B. R. Jones and R. B. Montador, 1988, "Tax reform in OECD countries: Motives, constraints and practice", OECD Economic Studies, 185-226.

Haskins, R. (2006), Testimony to the Committee on Ways and Means, July 19.

Heady C., T. Mitrakos and P. Tsakloglou, 2001, "The distributional impact of social transfers in the EU: Evidence from the ECHP”, Fiscal Studies, 22, 547-65.

Immervoll, H. (2005), "Falling Up the Stairs: The Effect of 'Bracket Creep' on Household Incomes”, Review of Income and Wealth, 51(1), 37-62.

Immervoll, H., (2010), "Minimum Income Benefits in OECD Countries: Policy Design, Effectiveness and Challenges", OECD Social, Employment and Migration Working Papers, No. 100, OECD

Publishing, www.oecd.org/els/workingpapers.

Immervoll, H., H Kleven, C T Kreiner and N Verdelin, (forthcoming), "Optimal Tax and Transfer Programs for Couples with Extensive Labor Supply Responses”, Journal of Public Economics. http://dx.doi.org/10.1016/j.jpubeco.2011.06.005.

Immervoll, H., H. Levy, C. Lietz, D. Mantovani, C. O’Donoghue, H. Sutherland and G Verbist (2006), "Household Incomes and Redistribution in the European Union: Quantifying the Equalising Properties of Taxes and Benefits", in: D B Papadimitriou (ed.), The Distributional Effects of Government Spending and Taxation, Palgrave Macmillan.

Immervoll, H. and A. Llena-Nozal (2011), "Social policies for the Recovery", background paper for a meeting of OECD social policy ministers held in Paris, May 2-3. Available through www.oecd.org/social/ministerial and in the IZA Policy Papers series. 
Immervoll, H., P. Marianna and M. Mira d'Ercole, (2004), "Benefit Coverage Rates and Household Typologies : Scope and Limitations of Tax Benefit Indicators", OECD Social, Employment and Migration Working Papers, No. 20, OECD, Paris. www.oecd.org/els/workingpapers.

Immervoll, H. and M. Pearson (2009), “A Good Time for Making Work Pay? Taking Stock of In-work Benefits and Related Measures across the OECD", OECD Social, Employment and Migration Working Papers, No. 81, OECD, Paris. www.oecd.org/els/workingpapers.

Immervoll, H., A. Peichl and K. Tatsiramos, eds., (2011), Who Loses in the Downturn? Economic Crisis, Employment and Income Distribution (Research in Labor Economics, Volume 32), Emerald Group Publishing Limited.

Jäntti, M. (1997), "Inequality in five countries in the 1980s: The role of demographic shifts, markets and government policies", Economica, 64, 415-40.

Jesuit, D. and V. Mahler (2004), "State Redistribution in Comparative Perspective: A Cross-national Analysis of the Developed Countries", Luxembourg Income Study Working Paper, No. 392.

Kakwani, N., 1977, "Measurment of tax progressivity: an international comparison", Economic Journal, v87, 71-80.

Karabarbounis, L. (2010), “One dollar, one vote”, Economic Journal, forthcoming.

Keen, M., H. Papapanagos, and A. Shorrocks (2000), “Tax Reform and Progressivity”, Economic Journal, $110,50-68$.

Luxembourg Income Study (LIS) Database, http://www.lisdatacenter.org (multiple countries; microdata runs completed between November 1, 2010 and July 18, 2011). Luxembourg: LIS.

Marx, I. (2007), “The Dutch 'Miracle' Revisited: The Impact of Employment Growth on Poverty”, Journal of Social Policy, 36(3), 383-97.

McCarty, N. and J. Pontusson (2009), "The Political Economy of Inequality and Redistribution”, in: W. Salverda, B. Nolan and T. Smeeding, eds., Oxford Handbook of Inequality, 665-692, Oxford University Press.

Musgrave, R. and T. Thin (1948), "Income tax progression, 1929-1948”, Journal of Political Economy, 56, 498-514.

OECD (1986), Personal Income Tax Systems Under Changing Economic Conditions, OECD, Paris.

OECD (1993), Taxation in OECD Countries, OECD, Paris.

OECD (1995), Taxation, Employment and Unemployment, OECD Jobs Study, OECD, Paris.

OECD (2007a), Benefits and Wages. OECD Indicators, OECD, Paris.

OECD (2007b), “The Balance Between Direct and Indirect Taxes 1965-2006”, in: Revenue Statistics 2007, OECD, Paris.

OECD (2008a), Growing Unequal? Income Distribution and Poverty in OECD Countries, OECD, Paris. 
OECD (2008b), "Tax reforms and tax burdens 2000-2006", in: Taxing Wages 2006/2007, OECD, Paris, 23-55.

OECD (2011a), Sickness, Disability and Work: Breaking the Barriers: A Synthesis of Findings across OECD Countries, OECD, Paris.

OECD (2011b), Pensions at a Glance 2011: Retirement-income Systems in OECD and G20 Countries, OECD, Paris.

OECD (2011d), Causes of Growing Inequality, OECD, Paris.

OECD (forthcoming), "Income Distribution and Growth" (working title), Economics Department, ECO/CPE/WP1(2010)16.

Pechman, J. A., ed., 1987, Comparative Tax Systems: Europe, Canada, and Japan, Tax Analysts, Arlington, VA.

Pechman, J. A., ed., 1988, World Tax Reform. A Progress Report, Brookings Institution, Washington, DC.

Pierson, P. (1995), Dismantling the Welfare State? Reagan, Thatcher and the Politics of Retrenchment, Cambridge University Press.

Rosen, Harvey (1977). “Is it Time to Abandon Joint Filing?”, National Tax Journal, 30, 423-28.

Riihelä, M., R. Sullström and I. Suoniemi (2008), "Tax progressivity and recent evolution of the Finnish income inequality", VATT Discussion Paper No. 460, VATT Government Institute for Economic Research, Helsinki.

Salverda, W., M. van Klaveren and M. van der Meer, eds., (2008), Low-Wage Work in the Netherlands, Russel-Sage.

Schwabish, J., T. M. Smeeding and L. Osberg, 2006, "Income Distribution and Social Expenditures”, in: D B Papadimitriou (ed.), The Distributional Effects of Government Spending and Taxation, Palgrave Macmillan.

Shorrocks, A. F. (1999), "Decomposition Procedures for Distributional Analysis: A Unified Framework Based on the Shapley Value", Wivenhoe Park: University of Essex and Institute for Fiscal Studies.

Smeeding, T. M. and J. P. Thompson (2011), "Recent Trends in Income Inequality: Labor, Wealth and More Complete Measures of Income", in: Immervoll, H., A. Peichl and K. Tatsiramos, eds., (2011), Who Loses in the Downturn? Economic Crisis, Employment and Income Distribution (Research in Labor Economics, Volume 32), Emerald Group Publishing Limited.

USDA (2010), Trends in Supplemental Nutrition Assistance Program Participation Rates: 2001 to 2008, United States Department of Agriculture.

Wagstaff A. and E. van Doorslaer, 2001, "What Makes the Personal Income Tax Progressive? A Comparative Analysis for Fifteen OECD Countries", International Tax and Public Finance, 8(3), 299-316.

Wagstaff A. and 24 other authors ,1999, "Redistributive effect, progressivity and differential tax treatment: Personal income taxes in twelve OECD countries", Journal of Public Economics, 72, 73-98. 
DELSA/ELSA/WD/SEM(2011)7

Yitzhaki, S., (1983), "On an Extension of the Gini Index", International Economic Review, 24, 617-28. 


\section{OECD SOCIAL, EMPLOYMENT AND MIGRATION WORKING PAPERS}

Most recent releases are:

No. 117 WHAT DRIVES INFLOWS INTO DISABILITY?Evidence from Three OECD Countries (2011) Ana Llena-Nozal and Theodora Xenogiani

No. 116 COOKING, CARING AND VOLUNTEERING: UNPAID WORK AROUND THE WORLD Veerle Miranda (2011)

No. 115 THE ROLE OF SHORT-TIME WORK SCHEMES DURING THE 2008-09 RECESSION Alexander Hijzen and Danielle Venn (2010)

No. 114 INTERNATIONAL MIGRANTS IN DEVELOPED, EMERGING AND DEVELOPING COUNTRIES: AN EXTENDED PROFILE

Jean-Christophe Dumont, Gilles Spielvogel and Sarah Widmaier (2010)

No. 113 ACTIVATION POLICIES IN JAPAN

Nicola Duell, David Grubb, Shruti Singh and Peter Tergeist (2010)

No. 112 ACTIVATION POLICIES IN SWITZERLAND

Nicola Duell and Peter Tergeist with contributions from Ursula Bazant and Sylvie Cimper (2010)

No. 111 ECONOMIC DETERMINANTS AND CONSEQUENCES OF CHILD MALTREATMENT

Lawrence M. Berger, Jane Waldfogel (forthcoming)

No. 110 DISTRIBUTIONAL CONSEQUENCES OF LABOR DEMAND ADJUSTMENTS TO A DOWNTURN: A MODEL-BASED APPROACH WITH APPLICATION TO GERMANY 2008-09

Herwig Immervoll, Olivier Bargain, Andreas Peichl, Sebastian Siegloch (2010)

No. 109 DECOMPOSING NOTIONAL DEFINED-CONTRIBUTION PENSIONS: EXPERIENCE OF OECD COUNTRIES' REFORMS

Edward Whitehouse (2010)

No. 108 EARNINGS OF MEN AND WOMEN WORKING IN THE PRIVATE SECTOR: ENRICHED DATA FOR PENSIONS AND TAX-BENEFIT MODELING

Anna Cristina D'Addio and Herwig Immervoll (2010)

No. 107 INSTITUTIONAL DETERMINANTS OF WORKER FLOWS: A CROSS-COUNTRY/CROSS-INDUSTRY APPROACH

Andrea Bassanini, Andrea Garnero, Pascal Marianna, Sebastien Martin (2010)

No. 106 RISING YOUTH UNEMPLOYMENT DURING THE CRISIS: HOW TO PREVENT NEGATIVE LONG-TERM CONSEQUENCES ON A GENERATION?

Stefano Scarpetta, Anne Sonnet and Thomas Manfredi (2010)

No. 105 TRENDS IN PENSION ELIGIBILITY AGES AND LIVE EXPECTANCY, 1950-2050

Rafal Chomik and Edward Whitehouse (2010)

No. 104 ISRAELI CHILD POLICY AND OUTCOMES

John Gal, Mimi Ajzenstadt, Asher Ben-Arieh, Roni Holler and Nadine Zielinsky (2010)

No. 103 REFORMING POLICIES ON FOREIGN WORKERS IN ISRAEL Adriana Kemp (2010)

No. 102 LABOUR MARKET AND SOCIO-ECONOMIC OUTCOMES OF THE ARAB-ISRAELI POPULATION Jack Habib, Judith King, Asaf Ben Shoham, Abraham Wolde-Tsadick and Karen Lasky (2010)

No. 101 TRENDS IN SOUTH AFRICAN INCOME DISTRIBUTION AND POVERTY SINCE THE FALL OF APARTHEID

Murray Leibbrandt, Ingrid Woolard, Arden Finn and Jonathan Argent (2010) 
No. 100 MINIMUM-INCOME BENEFITS IN OECD COUNTRIES: POLICY DESIGN, EFFECTIVENESS AND CHALLENGES

Herwig Immervoll (2009)

No. 99 HAPPINESS AND AGE CYCLES - RETURN TO START...? ON THE FUNCTIONAL RELATIONSHIP BETWEEN SUBJECTIVE WELL-BEING AND AGE

Justina A.V. Fischer (2009)

No. 98 ACTIVATION POLICIES IN FINLAND

Nicola Duell, David Grubb and Shruti Singh (2009)

No. 97 CHILDREN OF IMMIGRANTS IN THE LABOUR MARKETS OF EU AND OECD COUNTRIES: AN OVERVIEW

Thomas Liebig and Sarah Widmaier (2009)

A full list of Social, Employment and Migration Working Papers is available at www.oecd.org/els/workingpapers.

Other series of working papers available from the OECD include: OECD Health Working Papers. 


\section{RECENT RELATED OECD PUBLICATIONS:}

EQUAL OPPORTUNITIES? The Labour Market Integration of the Children of Immigrants (2010), via OECD Bookshop OECD REVIEWS OF LABOUR MARKET AND SOCIAL POLICIES: ESTONIA (2010), www.oecd.org/els/estonia2010 JOBS FOR YOUTH: GREECE (2010), www.oecd.org/employment/youth JOBS FOR YOUTH: DENMARK (2010), www.oecd.org/employment/youth OECD REVIEWS OF LABOUR MARKET AND SOCIAL POLICIES: ISRAEL (2010), www.oecd.org/els/israel2010

JOBS FOR YOUTH: UNITED STATES (2009), www.oecd.org/employment/youth JOBS FOR YOUTH: POLAND (2009), www.oecd.org/employment/youth OECD EMPLOYMENT OUTLOOK: Tackling the Jobs Crisis (2009), www.oecd.org/els/employment/outlook DOING BETTER FOR CHILDREN (2009), www.oecd.org/els/social/childwellbeing SOCIETY AT A GLANCE - ASIA/PACIFIC EDITION (2009), www.oecd.org/els/social/indicators/asia OECD REVIEWS OF LABOUR MARKET AND SOCIAL POLICIES: SLOVENIA (2009), www.oecd.org/els/slovenia2009 INTERNATIONAL MIGRATION OUTLOOK: SOPEMI (2010) www.oecd.org/els/migration/imo

PENSIONS AT A GLANCE 2009: Retirement-Income Systems in OECD Countries (2009), www.oecd.org/els/social/pensions/PAG

JOBS FOR YOUTH: FRANCE (2009), www.oecd.org/employment/youth SOCIETY AT A GLANCE 2009 - OECD Social Indicators (2009), www.oecd.org/els/social/indicators/SAG JOBS FOR YOUTH: AUSTRALIA (2009), www.oecd.org/employment/youth OECD REVIEWS OF LABOUR MARKET AND SOCIAL POLICIES: CHILE (2009), www.oecd.org/els/chile2009 PENSIONS AT A GLANCE - SPECIAL EDITION: ASIA/PACIFIC (2009),www.oecd.org/els/social/pensions/PAG SICKNESS, DISABILITY AND WORK: BREAKING THE BARRIERS (VOL. 3) - DENMARK, FINLAND, IRELAND AND THE NETHERLANDS (2008), www.oecd.org/els/disability GROWING UNEQUAL? Income Distribution and Poverty in OECD Countries (2008), www.oecd.org/els/social/inequality JOBS FOR YOUTH: JAPAN (2008), www.oecd.org/employment/youth JOBS FOR YOUTH: NORWAY (2008), www.oecd.org/employment/youth JOBS FOR YOUTH: UNITED KINGDOM (2008), www.oecd.org/employment/youth JOBS FOR YOUTH: CANADA (2008), www.oecd.org/employment/youth JOBS FOR YOUTH: NEW ZEALAND (2008), www.oecd.org/employment/youth JOBS FOR YOUTH: NETHERLANDS (2008), www.oecd.org/employment/youth For a full list, consult the OECD online Bookshop at www.oecd.org/bookshop. 
DELSA/ELSA/WD/SEM(2011)7 